UNITED STATES DEPARTMENT OF THE INTERIOR

Harold L. Ickes, Secretary

GEOLOGICAL SURVEY

W. C. Mendenhall, Director

Bulletin 911

\title{
ORE DEPOSITS IN THE VICINITY OF THE LONDON FAULT OF COLORADO
}

\author{
BY \\ QUENTIN D. SINGEWALD AND B. S. BUTLER
}

Prepared in cooperation with the

STATE OF COLORADO

and the

COLORADO METAL MINING FUND

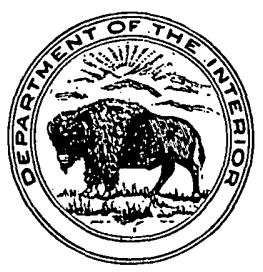

UNITED STATES

GOVERNMENT PRINTING OFFICE

WASHINGTON : 1941

For sale by the Superintendent of Documents, Washington, D. C. - - - . - - Price $\$ 1.50$ 



\section{CONTENTS}

Page

Abstract

Introduction

Location of the area

Scope of the paper... 4

Previous work

Acknowledgments.

Geography

Routes of approach

Topography _... 6

Climate and vegetation.... 6

General geology

Pre-Cambrian rocks.......... 7

Paleozoic sedimentary rocks_. 7

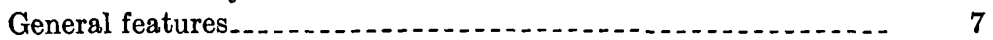

Sawatch quartzite (Upper Cambrian)

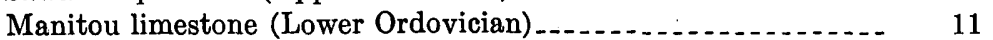

Chaffee formation (Upper Devonian) _.................. 12

Parting quartzite member._._. 12

Dyer dolomite member._._. 12

Leadville limestone (Mississippian) _.

Weber (?) formation (Pennsylvanian) _........ 14

Maroon formation (Permian and Pennsylvanian?) _......... 15

Tertiary (?) igneous rocks .

General features._. 15

White porphyries._. 17

White porphyry

Later white porphyry 18

Gray porphyry group. 18

Monzonitic diorite porphyry

Quartz monzonite porphyry

Lincoln porphyry ........ 21

Structure._._.

Regional structure........ 22

London fault._. 23

Quaternary geology

Economic importance.

Areas affected._. 27

Ore deposits. .

Regional relations

Deposits in the Alma district. 28

Distribution

Classification.......... 29

Gold veins of the London type 29

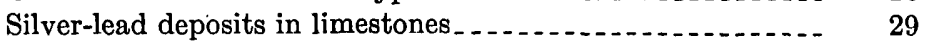

Gold deposits in the quartzites of the Sawatch formation..- $\quad 30$

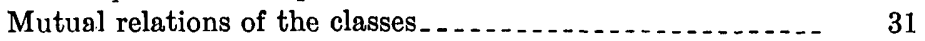


Ore deposits-Continued.

Regional relations-Continued. Page

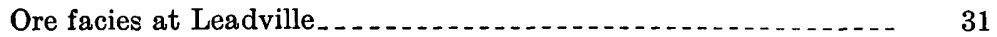

Relations of the ores at Alma to those at Leadville. . . . . . . . 33

Local centers of mineralization at Alma_............... 33

Origin of ores at Alma.

The London vein system

Location......... 35

London mine........... 36

History and production

Geologic map. ............. 37

Rocks................. 37

Pre-Cambrian rocks_......... 37

Paleozoic sedimentary rocks...

Tertiary (?) igneous rocks _. .

"Yellow porphyry"'........ 38

"Black graphitic" shale._._. 39

Structure ...

London fault.....

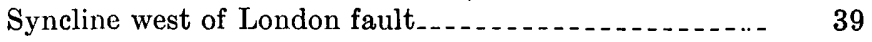

Minor faults whose strike is nearly parallel with that of the London fault . .

Transverse minor faults

Summary of folding and faulting

Occurrence of ore

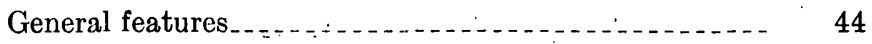

London vein $\ldots$

McDonald vein

Other ore bodies... 47

Relations of veins to enclosing rocks _._.

General appearance of ore

Detailed mineralogy of hypogene ore

Minerals in altered wall rock 49

Gangue minerals . . . . 50

Sulphide minerals

Gold

Summary of paragenesis.

Supergene alteration

Other mines of the London vein system 56

American mine...... 56

Havighorst tunnel

Ophir mine........ 57

Mosher tunnel

London-Butte mine

Deposits in London fault zone northwest of London Mountain.... 57

Area between London Mountain and New York Mountain._...- 58

Extent of prospecting

Venture shaft_............ 58

Hard-to-Beat mine

Oliver Twist tunnel

New York Mountain

Area northwest of New York Mountain

Conclusions regarding deposits in London fault zone north of Pennsylvania Mountain. 
Ore deposits-Continued.

Page

Region south of Pennsylvania Mountain

Extent of known mineralization.

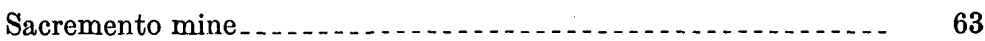

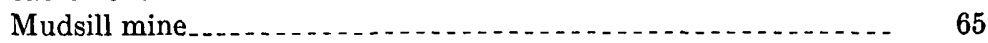

Sherwood mine........... 66

Wagner mine . . .

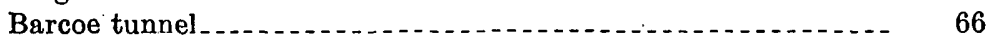

Other mines and prospects................................ 66

Conclusions regarding region south of Pennsylvania Mountain _. $\quad 69$

Suggestions for prospecting _........ 70

Region north of Pennsylvanis Mountain

Region south of Pennsylvania Mountain

Index . . . . . . . . . . 73

\section{ILLUS'TRATIONS}

Page.

Plate 1. Geologic map of the Alma-Horseshoe district, Colorado... In pocket

2. Geologic sections of the Alma-Horseshoe district........ In pocket

3. Generalized structure map of area near the London fault, showing relation of ore deposits to major structure

4. Glacial map of the Alma-Horseshoe district. . . . . . . . In pocket

5. Glacial map of area west of Fairplay . .

6. Plan and section of London mine... . .

7. Level maps of London, American, and Ophir mines and Havighorst and Mosher tunnels........................... In pocket

8. Sections $A-A^{\prime}$ to $G-G^{\prime}$ and section through South-side winze of London mine......... In pocket

9. Photomicrograph of yellow Weber (?) shale ("yellow porphyry") _ 50

10-17. Photomicrographs of ore and gangue from London vein......- 50

18. Index map of London-Butte mine showing relative position of various levels.

19. Geologic map and sections of London-Butte mine showing Butte and Maumee tunnels. . .

20. Geologic map of No. 3 and No. 4 levels, Iondon-Butte mine - In pocket

21. Geologic map and section of Oliver Twist tunnel.......... In pocket

FIGURE 1. Index map showing location of the Alma district........ 5

2. Age of ore deposits in relation to faulting and igneous intrusion_ $\quad 31$

3. Generalized columnar section at London Mountain .......... 38

4. Sketch showing relation between London fault, McDonald No. 2 vein, and a minor reverse fault at the top of raise 203, London Extension mine, Alma district................

5. Idealized section at London mine showing faults and ore bodies before period of post-mineral faulting ............-

6. Diagram of London Mountain showing southward-pitching syncline west of the London fault and stratigraphic and structural positions of veins before the post-mineral faulting.

7. Paragenesis of hypogene minerals in London vein .......

8. Sketch map of Sacremento mine

9. Geologic map and section of Mudsill mine

10. Map of Sherwood mine......

11. Map of Barcoe tunnel 


\section{TABLES}

TABLE 1. General stratigraphic section of the London fault region
2. Thickness of pre-Weber (?) units in the vicinity of the London fault region

3. Classification of the Tertiary (?) porphyries arranged according to their relative age .

4. Analyses of gangue carbonates, Alma district

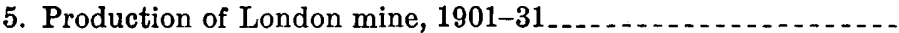




\title{
ORE DEPOSITS IN THE VICINITY OF THE LONDON FAULT OF COLORADO
}

\author{
By Quentin D. Singewald and B. S. Butler
}

\begin{abstract}
The London fault is one of the largest structural features in the Mosquito Range of central Colorado. Starting at the Mosquito fault, a mile west of the range crest, it extends southeastward diagonally across the range some 18 miles to South Park. The northern portion is within the Alma mining district. The topography at the range crest is very rugged, but South Park is a broad flat basin, and the London fault zone extends between these two extremes. Much of the area is difficult of access.
\end{abstract}

The oldest rocks of the area are pre-Cambrian injection gneiss and schist, granite, pegmatite, and granite gneiss, which have little economic importance. Unconformably overlying them is a series of Paleozoic sedimentary strata which have been divided into the following formations: (1) Sawatch quartzite (Cambrian), consisting chiefly of quartzite but including some thin-bedded limestones and shales at the top (Peerless shale member); (2) Manitou limestone (Ordovician); (3) Chaffee formation (Devonian), including Parting quartzite member overlain by Dyer dolomite member; (4) Leadville limestone (Mississippian); and (5) Weber (?) formation (Pennsylvanian), which consists of interbedded quartzite conglomerate, quartzite, arkose, shale, and limestone. The Maroon formation (Permian and Pennsylvanian ?), comprising the "red beds," overlies the Weber (?) formation in a small area. All the limestones, except those in the Maroon formation, are dolomitic. Erosional unconformities without a discordance in dip exist at the base of the Parting quartzite, at the base of the Leadville limestone, and at the base of the Weber (?) formation; in addition, one probably exists at the base of the Peerless shale member of the Sawatch quartzite. All known ore occurs in the strata near or below the base of the Weber (?) formation.

The abundant Tertiary (?) igneous rocks occur principally as sills in the sedimentary rocks and as dikes in the pre-Cambrian rocks. They are porphyries, close to quartz monzonite in composition. The oldest of them is the White porphyry, which is well known in the Leadville district and occurs mainly as thick sills. This is followed by the Gray porphyry group, which includes the Lincoln porphyry and two others that have not been given special names. This group in turn is followed by a later porphyry that closely resembles the White porphyry but occurs mostly in dikes that cut all the other bedrock formations. The White porphyry has a rather soft, dense whitish-gray groundmass that encloses sparse phenocrysts of quartz, dark muscovite, and, in places, feldspar. The Gray porphyry group includes those having a gray to very dark green dense groundmass that encloses numerous phenocrysts of plagioclase, ferromagnesian minerals, and, in places, quartz and orthoclase. The amount of hydrothermal alteration, produced as an end phase of intrusion, differs in each porphyry.

The regional dip of the strata is $10^{\circ}-25^{\circ} \mathrm{E}$. Departures from this dip occur close to major reverse faults or above the laccolithic sills that are present locally in the basal part of the Weber (?) formation.

In addition to innumerable minor faults, there are three major faults on the east side of the Mosquito Range. The largest is the London fault, which is reverse and dips steeply to the northeast. Its displacement exceeds 1,600 feet. The London fault is associated with an asymmetric anticline but does not coincide 
exactly with the axial plane of the anticline. Although impermeable clay gouge is in the main fault, auxiliary minor faults constitute a network of permeable fissures. The London and other large reverse faults in the Mosquito Range were formed during early Tertiary time as a result of stresses directed approximately S. $60^{\circ} \mathrm{W}$. They may be localized along lines of weakness developed by preCambrian faulting.

The Quaternary geology has economic interest because the depth of oxidation and enrichment in the ore deposits is related to the preglacial surface. The preglacial topography has been greatly modified at some places by erosion during at least two and possibly three stages of glaciation and at some other places by deposition of thick deposits.

The ore deposits along the London fault constitute part of a large group in the Mosquito Range; this paper therefore gives a brief discussion of the regional relations of the ores in the Alma district, and these are compared with the ores on the west side of the range.

Most of the important mines at Alma are either within a few hundred feet of the London fault on the footwall side, or within 4,000 feet of the Cooper Gulch fault on the hanging-wall side. Their distribution along these two major reverse faults is not uniform; they are bunched near local centers of mineralization. The principal types of ores are (1) gold-bearing quartz-sulphide veins of the London type, in or adjoining porphyry sills very close to the base of the Weber (?) formation, (2) silver-lead deposits in limestones, and (3) gold deposits in the quartzites of the Sawatch formation. Individual ore bodies are localized by minor faults. Gold deposits of each type are flanked by small silver-lead deposits, but the large silver-lead deposits apparently are grouped near an independent local center of mineralization.

The silver-lead deposits at Alma are classified with the distant facies of ore, recently described by Behre, on the west side of the range. The gold veins of the London type are classified with the typical mesothermal veins, described by Loughlin, in the Leadville district. The gold deposits in the quartzites of the Sawatch formation are classified as a variety of the typical mesothermal facies that formed in the presence of a much smaller quantity of ore-forming solutions than the veins in the Leadville district.

The age relations of the ores with respect to the Tertiary (?) intrusives and the faults suggest only one period of deposition. The ores formed from hydrothermal solutions exuded at depth from the same magma reservoir that earlier supplied the porphyries. Where the solutions were concentrated in trunk channels, as along the broken zones adjoining major reverse faults, they formed commercial deposits. Where there is much permeable clay gouge along the main fault the associated deposits are mainly in the footwall country rock, but where clay gouge is absent the associated deposits are in the hanging-wall country rock at some distance from the fault. In addition to serving as trunk channels for the ore solutions, the major reverse faults may have determined the location of protuberances in the magma, and such protuberances should be at places from which most of the ore-forming solutions tended to emanate.

The London vein system, worked chiefly in the London mint, has supplied most of the ore from the London fault zone. The vein system was discovered in 1873; its gross production to January 1,1932 , has been nearly $\$ 8,000,000$. The veins occur in auxiliary fissures that strike essentially parallel with the London fault but dip to the southwest, a little more gently than the strata, which are sharply upturned against the footwall of the main fault. At least 90 percent of the production has come from these veins where they are in or adjoining two contiguous sills of White porphyry and quartz monzonite porphyry that are very close to the base of the Weber (?) formation; the rest has come from the thin layer of Weber (?) formation below the lower sill and from the upper 
beds of the Leadville limestone. The veins are barren in rocks above the top of these sills. The important minor faults are divided into two main groups(1) faults that strike nearly parallel with the London fault and (2) transverse faults. The parallel faults originated before ore deposition, but many of them have had postmineral movements. The transverse faults had mainly postmineral movement.

A slightly glassy variety of milky quartz, in grains whose size ranges from microcrystalline to coarse, is the chief constituent of the veins. Pyrite, sphalerite, galena, and chalcopyrite are subordinate constituents, and native gold is seen only in pockets of exceptionally rich ore. Insignificant amounts of calcite are widespread. In addition, the veins contain included masses, layers, and filaments of partly replaced shale and porphyry. The gold and silver contents, in weight, are nearly equal. Close to the surface the veins were partly oxidized, but there is no evidence of noteworthy supergene enrichment. The paragenesis is (1) wall-rock alteration, consisting of replacement by quartz and sericite, (2) precipitation of coarse to medium-grained vein quartz, (3) brecciation, (4) deposition of fine-grained to microcrystalline quartz derived chiefly by solution and reprecipitation of earlier quartz, (5) deposition of pyrite, (6) slight brecciation accompanied by solution and reprecipitation of quartz, (7) deposition of sphalerite, chalcopyrite, and galena, in the order named, (8) deposition of gold, (9) slight brecciation, (10) solution and deposition of quartz accompanied by deposition of a little calcite, (11) slight brecciation, and (12) deposition of more calcite.

Unproductive veins of the London type have been found at several places west of the London fault between London Mountain and New York Mountain. Production west of the London fault has come only from the Hard-to-Beat mine, whose ore body, though about 25 feet above the base of the Weber (?) formation, differs somewhat from the veins of the London type. Although the lower part of the Weber (?) formation and the porphyry sills intruded into it have not been exhaustively prospected in this part of the region, the chances of finding ore in them are not very favorable.

New York Mountain is at the northern margin of the mineralized area whose center is London Mountain. Its production, which was small, came from silverlead replacement deposits in the Leadville limestone. The original (hypogene) ore consisted of unreplaced Leadville limestone, iron-bearing dolomite, chalcedony, sphalerite, galena, pyrite, chalcopyrite, and a "gray copper" mineral (tetrahedrite (?)); the sphalerite is lower in iron than that of the London mine and contains no chalcopyrite blebs derived through exsolution. The ore was partly oxidized and, probably, slightly enriched; limonite, calcite (travertine), anglesite (?), and covellite, products of oxidation and sulphide enrichment, are the only supergene minerals seen in the available specimens, but others probably existed in the ore.

The region northwest of New York Mountain is barren except near U. S. L. M. Little Corinne.

The lateral changes observed in the type and intensity of mineralization along the London fault north of Pennsylvania Mountain result from variations in three different geologic factors-(1) distance from the center of strongest mineralization, (2) Jocal structure, principally the steepness with which the strata dip away from the London fault, and (3) nature of the wall rock. London Mountain was a local center of mineralization in the Alma district. Ore deposits extend from this center northward as far as New York Mountain; the southern limit of the mineralized area has not yet been located. Gold deposits, mainly in siliceous rocks, occur at the center, and small silver-lead deposits in limestones at the margin. The small deposits at the range crest presumably are at the southern margin of another local center of mineralization that formerly existed near the Mosquito fault. 
South of Pennsylvania Mountain and east of the London fault the only mine with noteworthy gross production, valued at about $\$ 200,000$, is the Sacremento. The outputs of this and other mines in the vicinity were silver-lead ore of the "distant facies." These mines are in a mineralized area associated with a doubly plunging anticline at Sheep Mountain. Within the area barite is especially abundant in a belt roughly forming a semicircle open to the south. The chief silver production has been obtained close to the inner margin of the barite belt.

The rocks cropping out immediately west of the London fault and south of Pennsylvania Mountain are barren. Ore may exist, however, at more favorable horizons at depth. The area between Fourmile Gulch and Little Sacramento Creek has some possibilities. Prospecting could be done by diamond drilling but would be expensive.

Specific suggestions for prospecting are given at the end of the report.

\section{INTRODUCTION}

Location of the area.- The London fault zone lies partly within and partly to the south of the Alma district, Colorado, shown in figure 1. Beginning on the west side of the Mosquito Range less than a mile from the crest, the fault zone crosses the crest and extends some 18 miles southeastward diagonally across the range to South Park. As the crest of the range forms the boundary between Lake County and Park County, almost the entire region is in Park County.

Scope of the paper.-The geology and ore deposits of the Alma district have been studied by the writers since 1928, as part of the cooperative work of the United States Geological Survey, the State of Colorado, and the Colorado Metal Mining Fund. In order to make immediately available some of the results that should be of practical value to persons engaged in developing or prospecting, three preliminary reports have already been published. ${ }^{1}$ The purpose of this paper is to discuss briefly the regional relations of the important types of ore deposits in the entire Alma district, and to describe in detail the deposits along the London fault.

Previous work.-In 1886 Emmons, ${ }^{2}$ during his reconnaissance work in the Mosquito Range, mapped the London fault northwest of Round Hill. Nearly 30 years later Moore $^{3}$ described the fault at the London mine. At about the same time Patton ${ }^{4}$ revised the geology in the area north of Sacramento Creek. In 1927 a map showing the regional geology compiled from a number of sources was published in the Leadville professional paper by Loughlin $;^{5}$ he used

\footnotetext{
1 Singewald, Q. D., and Butler, B. S., Preliminary geologic map of the Alma mining district, Colo.: Colorado Sci. Soc. Proc., vol. 12, no. 9, pp. 295-308, 1930; Preliminary report on the geology of Mount Lincoln and the Russia mine, Park County, Colo.: Colorado Sci. Soc. Proc., vol. 12, no. 12, pp. 389-406, 1931; Suggestions for prospecting in the Alma district, Colo.: Colorado Sci. Soc. Proc., vol. 13, no. 4, pp. 89-131, 1933

2 Emmons, S. F., Geology and mining industry of Leadville, Colo.: U. S. Geol. Survey Mon. 12, 1886.

8 Moore, C. J., The London mine, Mosquito mining district, Park County, Colo.: Am. Inst. Min. Eng. Trans., vol. 45, pp. 415-427, 1913.

- Patton, H. B., Hoskin, A. J., and Butler, G. M., Geology and ore deposits of the Alma district, Park County, Colo.: Colorado State Geol. Survey Bull. 3, 1912.

Emmons, S. F., Irving, J. D., and Loughlin, G. F., Geology and ore deposits of the Leadville minine district, Colo.: U. S. Geol. Survey Prof. Paper 148, pl. 12, 1927.
} 
Patton's work for the area north of Sacramento Creek, and Emmons, reconnaissance, slightly modified, for the area to the south.

Acknowledgments.-Throughout the work Robert D. Butler has been an able assistant. In 1930 Robert E. Landon mapped part of

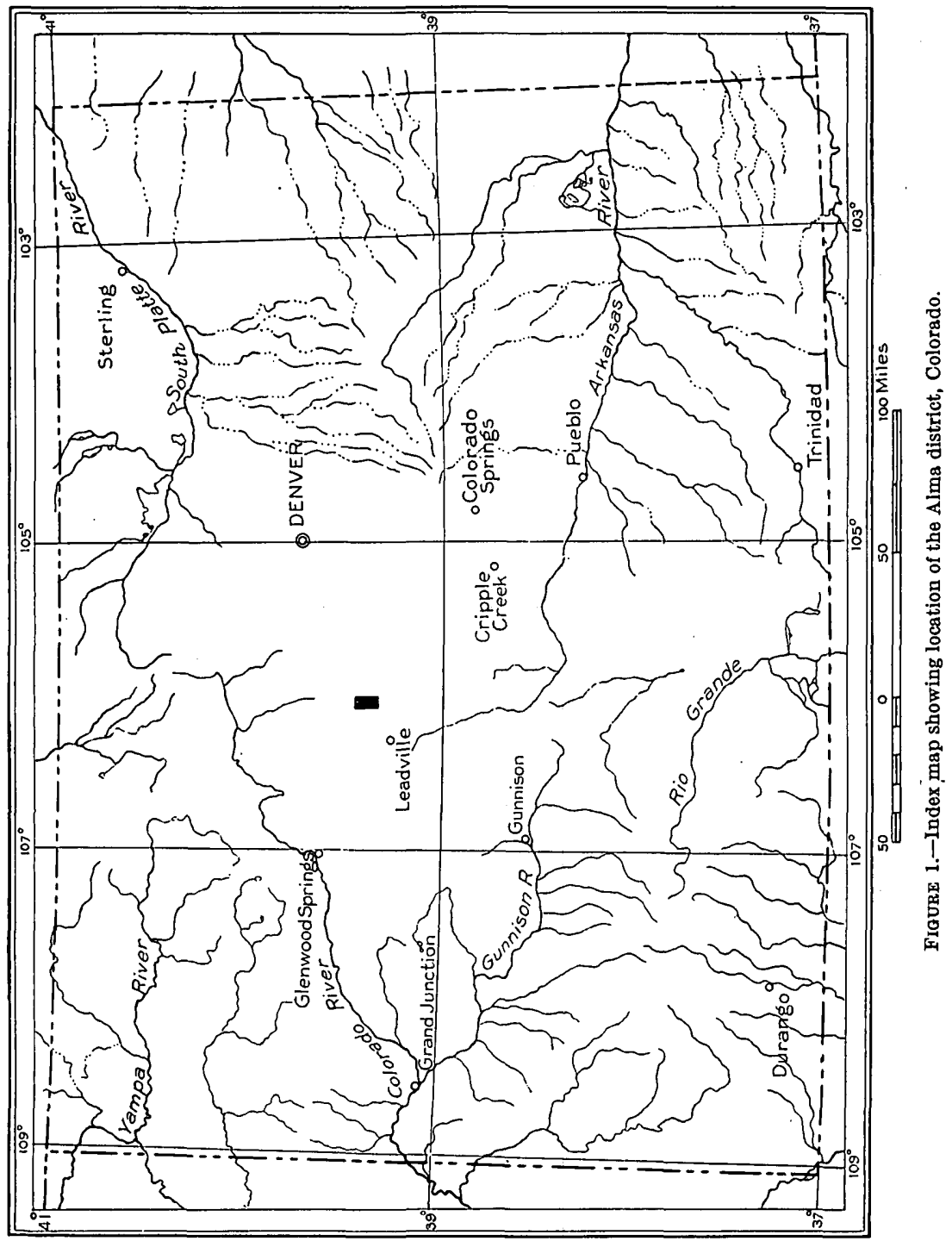

the pre-Cambrian area, and for 3 weeks in 1931 John M. Golden assisted in the underground work. In addition, John W. Vanderwilt, Tom S. Lovering, Charles H. Behre, Jr., G. F. Loughlin, and other members of the United States Geological Survey have contributed valuable suggestions in the field.

Adequate mention cannot be made of all the mining men who aided the work. The writers wish especially to thank Mr. Frank A. 
Aicher, of Denver, and Mr. S. J. Gately, then superintendent of the London mine. Mr. Aicher permitted the use of his excellent geologic maps of the North London, Butte, Oliver Twist, and American mines and supplied a great deal of other information; Mr. Gately furnished the base maps of the London mines, personally devoted a large amount of time which facilitated the underground mapping, and in other ways contributed valuable information and many courtesies. Special thanks are also due to Mr. G. F. Galloway, United States mineral surveyor at Alma, and to Miss Ada Dwelle, Mr. James N. Redman, Mr. Forbes Rickard, and Mr. Frank Briscoe.

\section{GEOGRAPHY}

Routes of approach.-The southeastern part of the region is accessible by means of several roads in or adjoining South Park. The part northwest of Sheep Mountain, however, is reached by only four roads, which are shown on plate 1. Those in Fourmile Gulch and South Mosquito Gulch are readily traveled by automobile; but the other two are so extremely rough or have grades so steep that automobile travel is difficult. The road on the north side of London Mountain has special interest because it is the former stage route from Fairplay to Leadville.

Topography.-The London fault zone diagonally crosses three physiographic units. (1) The northward-trending crest of the Mosquito Range, with many cirques at different altitudes, hanging valleys, and sharp ridges, forms very rugged topography having a relief of several thousand feet; (2) east of this highly dissected portion of the range a few small streams flowing in wide and deep, very steep-sided, U-shaped valleys cut through a moderately smooth upland that slopes eastward toward the valley of the South Platte River; (3) South Park, east of the Mosquito Range, is a broad, flat basin in which a few low ridges trend northwestward.

Climate and vegetation.-The climate is moist and, owing to the high altitude, colder than that of most regions in the same latitude. The winters are long and cold, the summers short and cool. Most of the snowbanks disappear toward the end of the summer, but a few remain throughout the year. During June, July, and August hail is frequent and even snow flurries may occur.

Most of the region lies within the Pike National Forest. Pine, aspen, and piñon are the principal trees below timber line, which is at about 11,500 feet. 


\section{GENERAL GEOLOGY PRE-CAMBRIAN ROCKS}

Injection gneiss, quartz-mica schist, granite, granite gneiss, and pegmatite are the most abundant of the pre-Cambrian rocks exposed in or near the region. The quartz-mica schist and related rock types apparently are the metamorphosed equivalents of a thick series of somewhat sandy shales containing a few lenses of nearly pure sandstone. The schist has been so permeated by granitic and pegmatitic material that almost everywhere it is transformed into an injection gneiss. The injection gneiss and schist are correlated with the Idaho Springs formation ${ }^{6}$ of the Front Range. Two types of granite are intrusive into the schist. The predominant type is a fine- to mediumgrained light-gray biotite-muscovite granite that Butler and Vanderwilt ${ }^{7}$ have correlated with the Silver Plume granite. The other type is a coarse-grained, somewhat porphyritic, usually pink biotitemuscovite granite, having a parallel or flow structure, which occurs only in small masses in the vicinity of London Mountain. It may tentatively be correlated with the Pikes Peak ${ }^{8}$ ( $\dagger$ Rosalie) ${ }^{9}$ granite. The pegmatites are genetically related to the granites. The granite gneiss is a very light-colored rock containing small quantities of biotite.

The pre-Cambrian rocks in the Alma district have been mapped chiefly by R. E. Landon and J. W. Vanderwilt. The rocks have relatively little economic importance and therefore are not further considered in this paper.

\section{PALEOZOIC SEDIMENTARY ROCKS \\ GENERAL FEATURES}

The sedimentary rocks in the vicinity of the London fault zone are shown in table 1. The basal part of the Weber (?) formation and the underlying strata have particular interest because they contain all the known ore. Descriptions and thicknesses given for them are derived from detailed sections, measured by the writers, east of the London fault in the Alma district. Special attention is called to the lithologic units within certain of the formations, as their recognition permitted more accurate structural mapping than if an entire formation had been considered a unit, in spite of the fact that most of them lack sharp boundaries. Thicknesses vary somewhat from place to place, but no progressive regional change has yet been determined for any of the formations of the Mosquito Range. In table 2 the thicknesses of the pre-Weber (?) formations in the Alma district are compared with their thicknesses at other localities where sections have been measured near the London fault.

\footnotetext{
- Lovering, T. S., Geologic history of the Front Range, Colo.: Colorado Sci. Soc. Proc., vol. 12, no. 4 pp. 63-65, 1929.

7 Butler, B. S., and Vanderwilt, J. W., The Climax molybdenum deposit of Colorado: Colorado Sci. Soc. Proc., vol. 12, no. 10, p. 327, 1931.

8 Lovering, T. S., op. cit., pp. 69-71.

- A dagger ( $\dagger$ ) preceding a geologic name indicates that the name has been rejected or abandoned for use in classiffcation in the publications of the U.S. Geological Survey.
} 


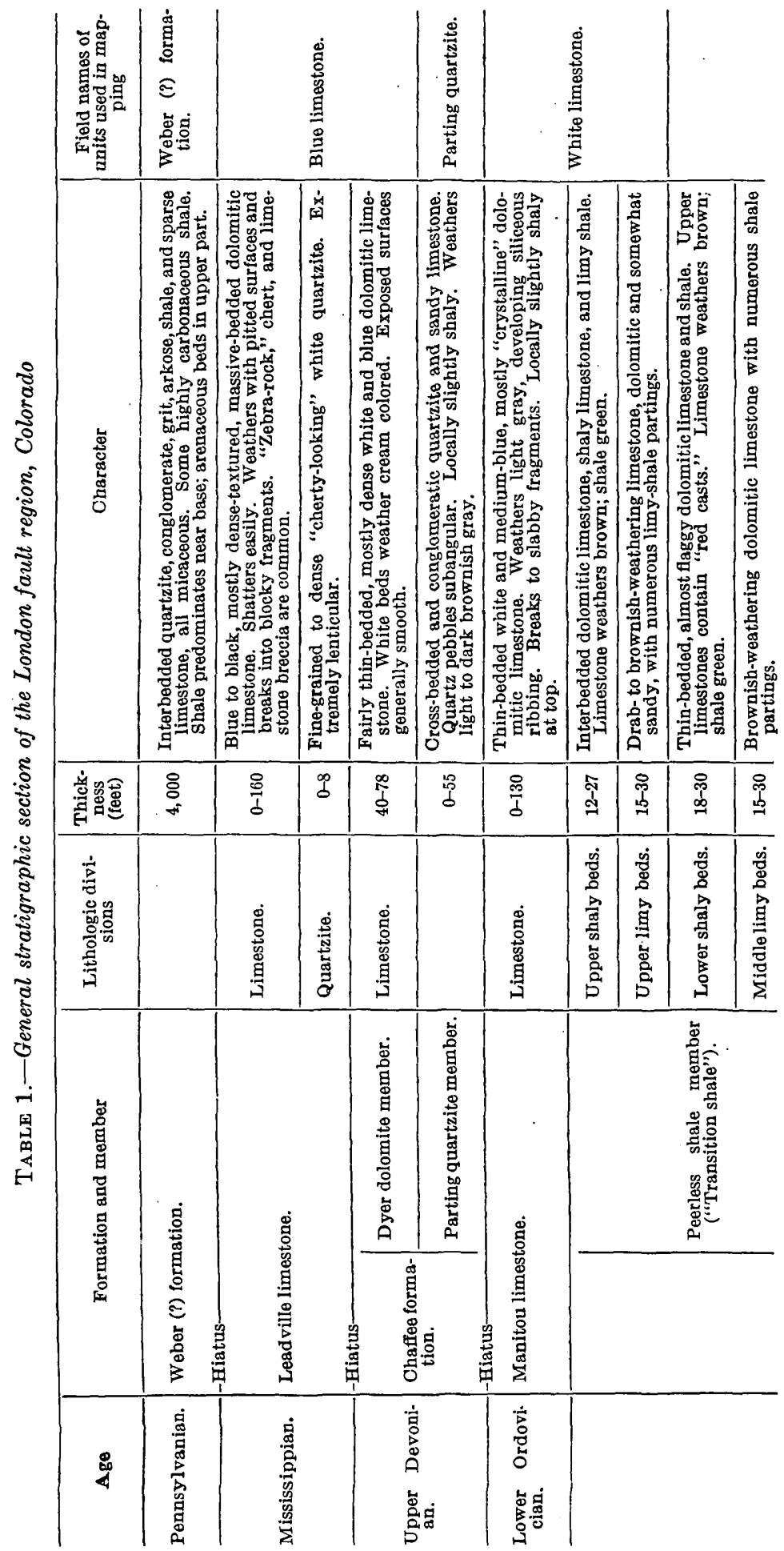


GENERAL GEOLOGY

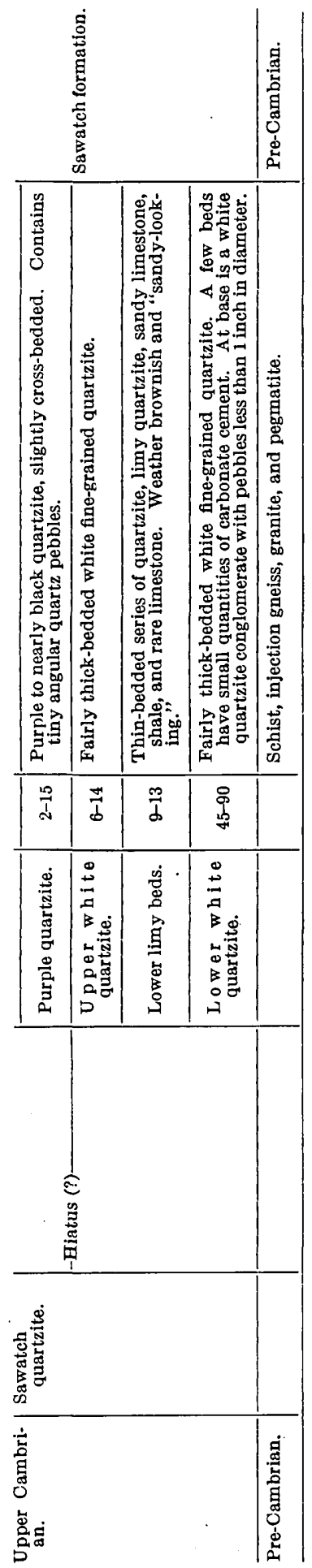


TABLE 2.-Thickness, in feet, of pre-Weber (?) units in the vicinity of the London fault region

\begin{tabular}{|c|c|c|c|c|c|}
\hline Measured unit & $\mid \begin{array}{c}1 \\
\text { Alma dis- } \\
\text { trict (except } \\
\text { near Mount } \\
\text { Lincoln) }\end{array}$ & $\begin{array}{c}2 \\
\text { Sheep } \\
\text { Moun- } \\
\text { tain }\end{array}$ & $\begin{array}{c}3 \\
\text { Iowa } \\
\text { Gulch }\end{array}$ & $\begin{array}{c}4 \\
\text { Mount } \\
\text { Evans }\end{array}$ & $\begin{array}{c}5 \\
\text { Horseshoe } \\
\text { A mphi- } \\
\text { theater }\end{array}$ \\
\hline $\begin{array}{l}\text { Leadville limestone } \\
\text { Dyer dolomite member of Chaffee formation } \\
\text { Parting quartzite member of Chaffee formation.- } \\
\text { Manitou limestone and upper two divisions of } \\
\text { Peerless shale member of Sawatch quartzite.. } \\
\text { Sawatch quartzite (in part): } \\
\text { Lower three divisions of Peerless shale } \\
\text { member.... } \\
\text { Quartzite.... }\end{array}$ & $\begin{array}{r}140-168 \\
40-65 \\
10-55 \\
\\
110-190\end{array}$ & $\begin{array}{r}115 \\
110 \\
65 \\
130\end{array}$ & $\begin{array}{r}163 \\
75 \\
27 \\
95\end{array}$ & $\begin{array}{r}145 \\
78 \\
21 \\
93\end{array}$ & $\begin{array}{r}167 \\
53 \\
34 \\
191\end{array}$ \\
\hline
\end{tabular}

1. Sections measured by the writers.

2. Section measured by Q. D. Singewald and R. D. Butler.

3. Sections measured by C. H. Behre, Jr. (revision of structure and stratigraphy in the Mosquito Range and the Lead ville district, Colo.: Colorado Sci. Soc. Proc., vol. 12, p. 40, 1929).

4. Sections measured by C. H. Behre, Jr. (written communication to writers)

5. Sections measured by J. H. Johnson (written communication to writers).

\section{SAWATCH QUARTZITE (UPPER CAMBRIAN)}

As has been noted by all previous writers, the Sawatch quartzite was deposited upon a surface of pre-Cambrian rocks that had been eroded to a remarkably smooth peneplain. The lower half of the formation, being almost entirely quartzite, resists erosion and tends to form prominent cliffs, whereas the upper half, composed of limestone and shale, is easily eroded and therefore tends to form distinct benches, many of which are covered by talus. Eight lithologic units may be recognized in the Sawatch formation. These are, in ascending order, (1) the lower white quartzite, (2) the lower limy beds, (3) the upper white quartzite, (4) the purple quartzite, (5) the middle limy beds, (6) the lower shaly beds, (7) the upper limy beds, and (8) the upper shaly beds. The upper five units compose the beds called transition shales by Emmons ${ }^{10}$ and now known as the Peerless shale member, from exposures on the northwest slope of Peerless Mountain, about 6 miles south-southwest of Leadville.

For convenience of mapping, the top of the Sawatch formation was drawn in the field a foot or two above the uppermost limestone containing red casts, ${ }^{11}$ where there is a fairly distinct change in lithology from thin bedded shale and limestone to thicker bedded limestone. This dividing line includes the upper two units of the Peerless member with the overlying Manitou limestone, as shown in the table on page 8 .

At the base of the formation is a conglomerate, 8 to 12 inches thick, in which quartz pebbles of various sizes, but few exceeding an inch in diameter, are enclosed in a matrix of fine-grained white quartzite. This grades upward through several feet of quartzite and quartzite conglomerate into fine-grained white quartzite. Bedding planes are

\footnotetext{
10 Emmons, S. F., Irving, J. D., and Loughlin, G. F., op. cit. (Prof. Paper 148), p. 25.

11 Emmons, S. F., op. cit. (Mon. 12), p. 59 and pl. 5. Emmons, S. F., Irving, J. D., and Loughlin, G. F., op. cit. (Prof. Paper 148), p. 26 and pl. 36, $B$.
} 
6 inches to 3 feet apart. A few layers in the lower white-quartzite zone have a calcareous cement; where fresh they are almost indistinguishable in appearance from the pure quartzite, but they weather brownish and sandy. The lower limy beds consist of thin-bedded fine-grained quartzite, sandy limestone, shale, and, rarely, dense limestone. These rocks are overlain by fine-grained white quartzite resembling that of the lower quartzite.

Above the upper white quartzite is an easily recognized marker. It consists of fine-grained, slightly conglomeratic quartzite that weathers purplish to blackish. Small angular quartz pebbles, seen only upon close inspection, commonly reveal cross-bedding. This purple quartzite everywhere has a sharp contact with the underlying white quartzite but at places grades upward through intercalated limestone and purple quartzite into the overlying strata. Hence it is included in the Peerless shale member in spite of its siliceous composition. The relations suggest that there may have been a slight hiatus before its deposition.

The predominant rock in the middle limy beds is slightly sandy crystalline dolomitic limestone, whereas that in the overlying shaly beds is siliceous indurated shale, but limestone and shale are interbedded in both. Bedding planes are rather closely spaced throughout, and the lower shaly beds are flaggy. The color of the limestones, where fresh, ranges from white to brownish or greenish gray; the socalled "red casts" 12 are not confined to a single bed but in most places are present in several limestones in the upper 10 feet of the unit. The shales weather to green platy or fissile fragments, but on a fresh surface some are light-colored and others are dark.

In the northern part of the area the entire formation was mapped as a unit. In the southern part, however, the quartzites of the four lowermost zones were mapped as a unit, whereas the uppermost two zones were grouped with the "White limestone."

Fossils collected from the lower shaly beds of the Peerless member were identified by Edwin Kirk, of the United States Geological Survey, as being Upper Cambrian. Fossils that Cooper later collected from the upper shaly beds and the upper limy beds immediately underlying the Manitou are also of Upper Cambrian age, and therefore the United States Geological Survey now includes these strata in the Peerless shale member of the Sawatch quartzite.

\section{MANTTOU LIMESTONE (LOWER ORDOVICLAN)}

The Manitou limestone in this region consists of thin-bedded white and medium-blue, mostly crystalline dolomitic limestone that weathers light gray, develops siliceous ribbing, and breaks to slabby frag-

12 Emmons, S. F., Irving, J. D., and Loughlin, G. F., op. cit., pl. 36, B.

$156659-41-2$ 
ments. Locally it is slightly shaly at the top. It is equivalent to the Manitou limestone to the southeast.

In the field the upper two lithologic units of the underlying Peerless shale member of the Sawatch quartzite, as that member is now defined by the United States Geological Survey, were mapped with the Manitou limestone, because of lack of definite boundaries, although the Manitou limestone is unlike the two units at the top of the Peerless member. A diagnostic feature is the presence of thin siliceous bands that on a weathered surface project out as a pronounced ribbing, mainly parallel to the bedding. Most of the ribs are less than one-sixteenth of an inch thick, but in the upper part of the formation a few are as much as 1 inch thick. The limestone is predominantly pale bluish gray, but some is white; it weathers gray or white. A few beds have dense texture, but most of them consist of medium-grained crystalline rock. The two upper units of the Peerless member are described in the table on page 8.

\section{CHAFFEE FORMATION (UPPER DEVONIAN)}

Parting quartzite member.-In 1886 Emmons ${ }^{13}$ used the name "Parting quartzite" as a descriptive term denoting its stratigraphic position between two thick limestones in the Leadville district. It now ranks as the lower member of the Chaffee formation, as is explained by Kirk $^{14}$ in his description of the Devonian rocks in central Colorado. An erosional unconformity without discordance in dip separates it from the underlying Manitou limestone.

Where not eroded, the Parting quartzite probably is present throughout the London fault region. Its lithology and thickness are not constant, owing to differences in composition and the amount of material deposited. ${ }^{15}$ Where thick it consists of nearly pure quartzite, but where thin it is very limy. In general it consists of brownishgray gritty quartzite, limy quartzite, or sandy limestone; most beds are conglomeratic and cross-bedded, but a few are even-grained. At places it contains a few shale partings.

Dyer dolomite member.-The name "Blue limestone" was applied by Emmons $^{16}$ to all the strata lying between the Parting quartzite and the Weber (?) formation. These strata may be divided into three lithologic units-a lower limestone, a middle quartzite, and an upper limestone. The lower limestone, which is of Devonian age, has been named the Dyer dolomite by Behre. ${ }^{17}$ It is now treated as the upper member of the Chaffee formation in the Mosquito Range. The upper

\footnotetext{
13 Emmons, S. F., op. cit. (Mon. 12), p. 61.

14 Kirk, Edwin, The Devonian of Colorado: Am. Jour. Sci., 5th ser., vol. 22, pp. 227-228, 1931.

15 Singewald, Q. D., Depositional features of the "Parting" quartzite near Alma, Colo.: Am. Jour. Sci., 5th ser., vol. 22, pp. 404-413, 1931.

to Emmons, S. F., op. cit., pp. $63-66$.

17 Behre, C. H., Jr., The Weston Pass mining district, Lake and Park Counties, Colo.: Colorado Sci. Soc. Proc., vol. 13, no. 3, p. 60, 1932.
} 
two lithologic units, which are of Mississippian age, constitute the Leadville limestone as redefined by Kirk ${ }^{18}$ in 1931.

At many places in the Alma district it was impossible to locate the contact between the Dyer dolomite and the Leadville limestone closely, and they were therefore mapped together. In the region to the south, however, they were mapped separately.

The Dyer dolomite member consists of thin to moderately thick, well-bedded, mostly dense-textured dolomitic limestone of either creamy-white or dark-blue color; layers of one color alternate with those of the other. The rock weathers to very smooth, "soft-looking" surfaces whose color ranges from bluish gray to pale yellow. Siliceous ribs like those in the Manitou limestone are present in a few places. Locally the base is transitional with the Parting quartzite.

LEADVHLE LIMESTONE (MISSISSIPPLAN)

Above the Dyer dolomite member of the Chaffee formation is a sandy bed whose widespread occurrence was first noted by Behre, ${ }^{19}$ who states that-

it ranges from 2 to 12 feet in thickness and averages about 8 feet. $* * *$ The typical sandstone is white, with sugary texture and medium- to coarse-grained. * * * Its grains are held in a calcareous and siliceous matrix. In some places it approaches a quartzite in character, and in others it is little more than a limestone with numerous quartz grains. In parts of the Leadville district it seems to be represented by shaly instead of sandy layers.

North of Mosquito Creek in the Alma district the sandy bed is extremely lenticular and where present is so fine-grained as to resemble a chert. On Pennsylvania Mountain it is faintly conglomeratic but does not at all resemble the Parting quartzite. South of Pennsylvania Mountain it is persistent. Kirk states that a pronounced erosional unconformity exists below this sandy bed.

According to Behre, a conspicuous limestone breccia, 2 to 5 feet thick, generally overlies the sandy zone. The overlying strata consist of massive and rather obscurely bedded dark-blue to nearly black, dense to very fine-grained dolomitic limestone with a few beds of limestone breccia. A striking characteristic is the tendency toward intense shattering; this property has a marked influence on ore deposition, for it provides an otherwise nonporous limestone with channels of circulation so that large rock masses may be completely permeated. Chert nodules and streaks are common, and most of them are black but a few are light-colored. The weathered limestone has extremely pitted surfaces. A few beds weather light brown, but the color is usually dark blue, alternate bands often having slightly different shades. Throughout the limestone so-called "zebra rock"

18 Kirk, Edwin, op. cit., p. 229.

10 Behre, C. H., Jr., Revision of structure and stratigraphy in the Mosquito Range and the Leadville District, Colo.: Colorado Sci. Soc. Proc., vol. 12, pp. 38-41, 1929. 
is common. "Zebra rock" is limestone that has been recrystallized and partly replaced by veinlets of white dolomite so spaced as to give the rock a striped appearance. Patches of "zebra rock" have irregular shape and range from an inch to many feet in longest dimension.

\section{WEBER (?) FORMATION 20 (PENNSYLVANIAN)}

The Weber (?) formation rests upon the Leadville limestone, apparently with concordant dip, but is separated from it by an erosional unconformity. The strata constituting the Weber (?) formation consist of interbedded lenticular and, commonly, cross-bedded micaceous quartzite, sandstone, grit, arkose, conglomerate, sandy shale, and shale, with a few beds of limy shale and limestone. The presence of mica is a distinctive feature even in most of the limestones. Some strata contain marine fossils, but many have root and tree imprints that indicate a continental origin. As no two sections show the same sequence of beds, lithologic subdivision of the formation is impossible. The lower part is more shaly than the upper, but within the area mapped no definite boundary can be drawn between the lower part (Weber shales of early reports) and the upper part (Weber grits of early reports).

Arenaceous beds constitute most of the formation. In general, they increase in both abundance and coarseness of grain toward the top. Their color ranges from whitish to dark gray. Almost all are conglomeratic, more or less arkosic, and cross-bedded. The highly arkosic strata are rather friable on weathered surfaces; but the others are so firmly cemented as to be quartzitic. Pebbles of the conglomerate are predominantly quartz and subordinately feldspar, the amount of feldspar varying considerably from place to place and from bed to bed; a few pebbles consist of pre-Cambrian pegmatite, and fewer of schist.

The shales are colored dark gray to black, green, less commonly light gray or yellow, and rarely red. Weathered outcrops commonly have fissile structure. Most of the shale is sandy, probably having been deposited as silt, but other beds are clayey, and a few are limy. Some of the black shales, especially those near the base, are highly carbonaceous. The limestone of the Weber (?) formation is dark gray to black, has fine-grained texture, and weathers brown.

Throughout a large part of the area there occurs at or near the base a bed of yellow shale which has undergone considerable alteration. This is known locally among mining men as "cap rock" or "yellow porphyry."

${ }^{20}$ For an account of the paleontologic relations of the Weber (?) formation see Johnson, J. H., Paleozoic formations of the Mosquito Range, Colo.: U. S. Geol. Survey Prof. Paper 185-B, p. 27-43, 1934. 


\section{MAROON FORMATION (PERMIAN AND PENNGYLVANIAN?)}

The type locality for the Maroon formation is Maroon Creek, just north of the Anthracite-Crested Butte area. In the Tenmile and Breckenridge districts the name Maroon formation has in previous reports been applied to about 1,500 feet of strata overlying the Weber (?) formation, although these strata correspond to only a part of the thick section at the type locality. In making a resurvey of the Breckenridge district, Lovering ${ }^{21}$ found that the lower part of the beds previously called "Wyoming formation" in that region includes beds that appear properly to belong to the Maroon formation, and younger beds that belong to the Morrison formation. He therefore used the name Maroon to include all the beds above the Weber (?) formation and below the Morrison, which is now classified as Upper Jurassic. This paper follows Lovering's usage. The Morrison formation, however, is not present in the vicinity of the London fault zone.

The Maroon formation is widespread in the London fault zone south and east of Sheep Mountain and in adjoining parts of South Park. The lower part, which is transitional with the Weber (?) formation, is an interbedded series of arkose, arkose conglomerate, sandy shale, shale, and limestone. Shale and limestone are more abundant than in the upper part of the Weber (?) formation. The sandy layers, which are highly feldspathic, are commonly cross-bedded. Their prevailing color near the surface is dull red, owing to oxidation of iron in the matrix, but it usually changes at depth to greenish gray. The shales are dull red, gray, or black. The limestones are nondolomitic, have dense texture, weather drab to blue, and thus differ from the crystalline brownish-weathering dolomitic limestones of the Weber (?) formation.

The upper part of the formation consists of micaceous arkose, arkose conglomerate, and sandy shale with very little shale or limestone. The limestones are bluish, but the rest of the strata are brick red. Cross-bedding is common in the sandy layers.

\section{TERTIARY (P) IGNEOUS ROCKS}

\section{GENERAL FEATURES}

Intrusive igneous rocks of late Cretaceous or early Tertiary age are abundant in the northern part of the Mosquito Range, which lies within "the belt ${ }^{22}$ of $* * *$ intrusive porphyries" extending southwestward from Boulder County, in central Colorado. They occur as sills, dikes, and stocks, and in all these modes of occurrence they range in composition from quartz-bearing diorite to granite.

\footnotetext{
"1 Lovering, T. S., Geology and ore deposits of the Breckenridge district, Colo.: U. S. Geol. Survey Prof. Paper 176, pp. 4-5, 1934.

22 Spurr, J. E., and Garrey, G. H., Economic geology of the Georgetown quadrangle (together with the Empire district), Colorado, with general geology by S. H. Ball: U. S. Geol. Survey Prof. Paper 63, pp. 67-71, 1808.
} 
In the vicinity of the London fault zone only sills and dikes are exposed. The sills occur in all the sedimentary formations but, as in other parts of the range, have their greatest development in the basal part of the Weber (?) formation. The dikes are mainly confined to the pre-Cambrian rocks, yet some occur in the sedimentary rocks. In this area, as at Leadville, the sills and dikes consist of White porphyry, the Gray porphyry group, and a later white porphyry. The units distinguished by the writers are listed in table 3 .

TABLE 3.-Classification of the Tertiary (?) porphyries arranged according to their relative age

\begin{tabular}{|c|c|c|c|}
\hline & & Characteristic megascopic appearance & Diagnostic features \\
\hline \multicolumn{2}{|c|}{ Later white porphyry. } & $\begin{array}{l}\text { In places has sheeted structure; soft } \\
\text { and compact whitish-gray ground- } \\
\text { mass; rare to fairly numerous pheno- } \\
\text { crysts of feldspar, quartz, and dark } \\
\text { muscovite. }\end{array}$ & $\begin{array}{l}\text { Some varieties distinguish- } \\
\text { able from White por- } \\
\text { phyry by means of feld- } \\
\text { spar phenocrysts; other } \\
\text { varieties indistinguish- } \\
\text { able. }\end{array}$ \\
\hline \multirow{3}{*}{$\begin{array}{l}\text { Gray porphyry } \\
\text { group. }\end{array}$} & Lincoln porphyry. & $\begin{array}{l}\text { Medium-gray groundmass; numerous } \\
\text { medium-sized phenocrysts of plagio- } \\
\text { clase, quartz, and biotite, and scat- } \\
\text { tered pink rectangular orthoclase } \\
\text { crystals, half an inch to several } \\
\text { inches in length. }\end{array}$ & $\begin{array}{l}\text { Large pink orthoclase crys- } \\
\text { tals. }\end{array}$ \\
\hline & $\begin{array}{c}\text { Quartz monzonite } \\
\text { porphyry. }\end{array}$ & $\begin{array}{l}\text { Usually considerably altered; medium } \\
\text { greenish-gray groundmass; numer- } \\
\text { ous phenocrysts of plagioclase, horn- } \\
\text { blende, biotite, and quartz. }\end{array}$ & $\begin{array}{l}\text { Altered appearance, me- } \\
\text { dium-gray color, abun- } \\
\text { dance of visible quartz, } \\
\text { scarcity of hornblende. }\end{array}$ \\
\hline & $\begin{array}{c}\text { Monzonitic diorite } \\
\text { porphyry. }\end{array}$ & $\begin{array}{l}\text { Usually has fresh appearance; dark- } \\
\text { gray groundmass; numerous pheno- } \\
\text { crysts of plagioclase, hornblende, } \\
\text { biotite, and quartz. }\end{array}$ & $\begin{array}{l}\text { Fresh appearance, dark } \\
\text { color, abundance of horn- } \\
\text { blende, rare visible } \\
\text { quartz. }\end{array}$ \\
\hline \multicolumn{2}{|l|}{ White porphyry. } & $\begin{array}{l}\text { Soft and compact whitish-gray ground- } \\
\text { mass; extremely rare phenocrysts of } \\
\text { quartz and dark muscovite. }\end{array}$ & $\begin{array}{l}\text { White color; scarcity of } \\
\text { phenocrysts. }\end{array}$ \\
\hline
\end{tabular}

The known stocks in the Mosquito Range are at some distance from the London fault zone. The one in the upper part of Buckskin Gulch ${ }^{23}$ (see pls. 1 and 2) apparently was localized by the Cooper Gulch fault, for it lies in the line of probable northward extension of this fault. Likewise, the one at Breece Hill ${ }^{24}$ must have been localized by the faults with which it is associated. Two other intrusives that may be stocks, closely associated with large faults, are described in the Leadville professional paper. It is of interest that all the known stocks and a large proportion of the dikes in the Mosquito Range lie within a belt, not more than 3 miles wide, extending northeastward from Leadville to North Star Mountain, and that this belt, which doubtless is along the crest of an underlying batholith whose apices are the stocks, roughly follows the contact between a mass of Silver Plume granite and the Idaho Springs formation.

\footnotetext{
${ }^{23}$ Singewald, Q. D., Igneous history of the Buckskin Gulch stock, Colo.: Am. Jour. Sci., 5th ser., vol. 24, pp. 52-67, 1932.

24 Emmons, S. F., Irving, J. D., and Loughlin, G. F., op. cit. (Prof. Paper 148), p. 55.
} 
Owing to their light color, the white porphyries can often be recognized at a distance. The earlier of the white porphyries, which is older than the Gray porphyry group and equivalent to the White porphyry in the Leadville district, is termed the "White porphyry." A later white porphyry is clearly younger than the Gray porphyry group. The two white porphyries can be distinguished from each other with certainty only where their age relations can be determined. In general, however, feldspar phenocrysts are absent or exceedingly rare in the White porphyry but are fairly common in the later white porphyry; moreover, the White porphyry usually occurs as sills and the later white porphyry as dikes in the sedimentary rocks.

\section{WHITE PORPHYRY}

The White porphyry is widespread along and in the London fault zone. The detailed mapping north of Pennsylvania Mountain shows that an extensive sill occurs in the lower part of the Weber (?) formation throughout the area west of the London fault. This sill is cut at many places in the London mine.

In the typical White porphyry a few small to medium-sized quartz grains and dark muscovite flakes are sparsely scattered through a whitish-gray soft groundmass that appears homogeneous and dense to the naked eye. However, some facies contain no visible phenocrysts, and others have intensely altered white feldspar prisms in addition to quartz and muscovite. The fracture is very splintery. The rock weathers to flat fragments whose surfaces are commonly stained by limonite to a pale rusty-brown color and are coated with small dendritic films of black manganese oxide.

All specimens collected in the Alma district show intense hydrothermal alteration. Primary minerals of the groundmass, seen under the microscope, are orthoclase, very sodic plagioclase, and quartz. Usually they form a microgranular aggregate of anhedral grains whose diameter ranges from 0.001 to 0.1 millimeter but averages about 0.01 millimeter; rarely the texture is micropoikilitic, the feldspars being enclosed in rounded quartz grains averaging 0.1 millimeter in diameter or slightly larger. Abundant sericite and carbonate, the former predominating, are rather uniformly distributed impregnating or in intergrowths with the primary minerals. These secondary minerals were formed principally by replacement of feldspars and, to some extent, of quartz, but they may have been derived in part through alteration of former ferromagnesian constituents. Most of the sericite flakes are small, but a few, intergrown with clear secondary quartz, are relatively large.

Apatite, zircon, leucoxene, rutile, magnetite, and in some thin sections pyrite are scarce as accessory minerals. 
Phenocrysts are so sparsely distributed that they are absent or rare in the thin sections. Quartz is euhedral, subhedral, or rounded and embayed. Usually it is surrounded by a groundmass border whose quartz is in optic continuity with the phenocryst. Large matted aggregates of sericite, some of them containing numerous tiny leucoxene grains, are alteration products of former ferromagnesian minerals or feldspar. Likewise, large muscovite flakes having ragged outlines may have been derived through alteration of former biotite. The six-sided muscovite crystals probably originated under deuteric (pneumatolytic) conditions, as suggested by Loughlin. ${ }^{25}$

The intense sericite-carbonate type of alteration, described above, is regional and therefore must have taken place as an end phase of igneous activity at the time the porphyry was intruded, in a manner analogous to the end-phase alteration ${ }^{26}$ in other porphyries. Later, during the period of ore deposition, the rock adjoining the veins was still further altered by hydrothermal solutions. The local alteration at London Mountain is discussed with the mineralogy of the London mine.

\section{LATER WHITE PORPHYRY}

The later white porphyry apparently is not abundant in the London fault region. The rock is whitish gray and at places has sheeted structure. Its groundmass is like that of the White porphyry. Small to medium-sized phenocrysts of feldspar, quartz, and muscovite are fairly numerous in some phases and very scarce in others; they nowhere constitute more than 10 percent of the rock. Most of the feldspars are white, but some are pink. The rock fractures and weathers like the White porphyry.

Under the microscope the feldspar phenocrysts are seen to be both albite $\left(A b_{9} A n_{1}\right)$ and orthoclase, the former predominating. Both are altered to some extent, and some albite has been almost entirely replaced by sericite and carbonate. The groundmass which is microgranular, has a grain diameter in different specimens ranging from 0.01 to 0.05 millimeter. In all other respects, including the intense sericite-carbonate regional alteration, the rock closely resembles the White porphyry.

\section{GRAY PORPHYRY GROUP}

Rocks of the Gray porphyry group almost everywhere are darker and contain more phenocrysts than those of the white porphyries. Lithologically they may be divided into three main classes, which Patton ${ }^{27}$ designated diorite-porphyrite, quartz monzonite porphyry, and Lincoln porphyry. The last two names are retained. The term "porphyrite" has been discarded by the United States Geological Sur-

${ }^{25}$ Emmons, S. F., Irving, J. D., and Loughlin, G. F., op. cit., (Prof. Paper 148), p. 45.

${ }^{26}$ Singewald, Q. D., Alteration as an end phase of igneous intrusion in sills on Loveland Mountain, Park County, Colo.: Jour. Geology, vol. 40, pp. 16-29, 1932.

${ }_{27}$ Patton, H. B., Hoskin, A. J., and Butler, G. M., op. cit. (Colorado Geol. Survey Bull. 3), pp. 74-92. 
vey, and the local rocks to which it was applied prove to be near monzonite in composition, but as the term "diorite" is firmly established in local usage, the rocks are here called monzonitic diorite porphyry.

\section{MONZONITIC DIORITE PORPHYRY}

The monzonitic diorite porphyry is fairly widespread in the Alma district, but near the London fault zone north of Pennsylvania Mountain it is represented only by one dike. It probably is not common in the region south of Pennsylvania Mountain.

The rocks classed as monzonitic diorite porphyry may be distinguished by their dark gray color and by the abundance of hornblende and scarcity of quartz as phenocrysts. Usually they have a fresh appearance, but in places they are somewhat altered. In typical specimens profuse small to medium-sized phenocrysts of glassy plagioclase, shiny hornblende, scattered glistening biotite, and rarely quartz are embedded in a very dark greenish-gray dense groundmass. Many occurrences, especially the dikes, contain pre-Cambrian schist as scattered inclusions which reach several inches in maximum diameter. In weathering the rock loses its luster and its surfaces become stained brown by limonite.

As seen under the microscope, phenocrysts constitute from onefourth to one-third of the rock. They are, in their usual order of abundance, calcic andesine (close to $\mathrm{Ab}_{1} \mathrm{An}_{1}$ ), hornblende, biotite, and quartz. The accessory minerals commonly present are titaniferous magnetite, apatite, titanite, and zircon. Allanite was seen in one thin section. The finely microcrystalline groundmass consists of sodic plagioclase, less abundant orthoclase, quartz, hornblende, and small amounts of biotite. Much of the hornblende and a little of the plagioclase have anhedral prismatic outlines, but the rest of the grains are irregular. Alteration, produced by hydrothermal solutions as an end phase ${ }^{28}$ of the intrusion, took place in all masses of the rock but was less intense than in any other porphyry in the district. The secondary minerals, named in their usual order of abundance, are sericite, chlorite, white carbonate, epidote, leucoxene, and, locally, brown-weathering iron carbonate, albite $\left(\mathrm{Ab}_{9} \mathrm{An}_{1}\right)$, clinozoisite, rutile, quartz, and magnetite.

\section{QUARTZ MONZONITE PORPHYRY}

All the rocks of porphyritic texture that contain considerable amounts of visible plagioclase, quartz, and dark minerals and that do not contain large orthoclase crystals are classified as quartz monzonite porphyry. Their composition ranges from quartz monzonite to granodiorite. They were not intruded simultaneously, yet neither on the basis of composition nor on that of relative age can they be subdivided

${ }^{28}$ Singewald, Q. D., Alteration as an end phase of Igneous intrusion in sills on Loveland Mountain, Park County, Colo.: Jour. Geology, vol. 40, pp. 16-29, 1932. 
into units that are recognizable consistently in the field. They include rocks that Cross originally described, in the Leadville monograph, ${ }^{29}$ as porphyrite (division A), Mosquito porphyry, "green porphyry," and Sacramento porphyrite. Their representatives in the Leadville district are the Evans Gulch porphyry, the Mount Zion porphyry, and the Johnson Gulch porphyry in part. Quartz monzonite porphyry is more widely distributed and abundant in the London fault zone than any other porphyry. Most of the occurrences are ordinary sills or dikes, but that in the vicinity of Mount Evans is a thick laccolithic sill.

Owing to differences in texture, orginal composition, and the nature and extent of alteration, the appearance of the quartz monzonite porphyry differs considerably in different occurrences. The color of the least-altered rock is medium greenish gray, but highly altered or weathered exposures may be green, brown, light gray, or nearly white. In places the porphyritic texture is obscured as a result of the alteration. Numerous phenocrysts of feldspar, quartz, and what appear to be altered biotite and hornblende are embedded in a dense groundmass; rarely they have subparallel arrangement. In some varieties, locally called bird's-eye porphyry, feldspar and quartz phenocrysts are unusually large and conspicuous, ${ }^{30}$ the largest grains attaining a diameter of 1.0 centimeter; in others the phenocrysts are small and inconspicuous. The relative abundance of quartz phenocrysts varies. Near mineralized fissures, as in the London mine, this rock may be intensely sericitized and so much bleached that it resembles the white porphyries; however, the outlines of former phenocrysts, especially biotite, can be recognized upon close inspection, and the rock identified by their abundance.

Phenocrysts in the freshest specimens seen under the microscope are calcic andesine (close to $\mathrm{Ab}_{55} \mathrm{An}_{45}$ ), quartz, and biotite. Orthoclase is generally absent. In highly altered specimens the biotite is completely replaced and the plagioclase has a composition close to $A b_{9} A n_{1}$. Originally hornblende was a local minor constituent. Accessory minerals are titaniferous magnetite, apatite, zircon, titanite, and sporadic allanite. The groundmass before being altered was composed of sodic plagioclase, quartz, orthoclase, and a little biotite, and it has either a microgranular or a micropoikilitic fabric. With uncrossed nicols both fabrics appear the same, but between crossed nicols, in the micropoikilitic variety, nearby grains prove to consist of rounded aggregates of quartz and perhaps orthoclase as much as 0.5 millimeter in diameter which extinguish as a unit and enclose unoriented grains and microlites of the other minerals.

End-phase alteration usually has been intense, but less intense than in the white porphyries. The minerals that were formed during the

39 Emmons, S. F., op. cit. (Mon. 12), pp. 327-328, 334-338, 341-344.

${ }^{30}$ See Patton, H. B., Hoskin, A. J., and Butler, G. M., op. cit., pl. 12, A. 
deuteric and hydrothermal stages of intrusion include sericite, chlorite, white carbonate, and leucoxene; in addition, albite, fibrous green biotite, iron carbonate, epidote, clinozoisite, pyrite, rutile, and quartz are present in many specimens. These alteration minerals were introduced progressively ${ }^{31}$ in a sequence that may be divided into four stages. Albite and fibrous green biotite represent the first stage, and sericite, penninite, epidote, clinozoisite, leucoxene, rutile, and pyrite the second stage. The third stage is represented by more sericite, iron carbonate, and white carbonate, which replaced not only the original minerals but also epidote and penninite of the second stage. Introduction of still more white carbonate and a very small amount of quartz completed the process. The relative intensity of each stage determined the final composition of the rock, which varies from place to place. Undoubtedly the regional alteration in this and the other porphyries was accomplished by interaction of the early minerals with, first, magmaresiduum and then, at progressively lower temperatures, hot solutions derived in place or at shallow depth. The changes are analogous to but more widely distributed than the later alteration produced by the ore solutions in rock adjoining the veins. The factors that determine the nature of the changes produced by hydrothermal solutions acting on igneous rocks have been discussed by one of the writers ${ }^{32}$ in another paper.

\section{IINCOLN PORPHYRY}

Cross used the name "Lincoln porphyry," in the Leadville monograph, ${ }^{33}$ to designate the type of rock that crops out on the summit of Mount Lincoln. It is perhaps the most distinctive of the porphyries occurring in the belt of Tertiary (?) intrusives in central Colorado, and it has been widely correlated with rocks in many districts. It does not occur in the London fault zone, but it is widely distributed elsewhere in the Mosquito Range. In addition to forming normal sills and dikes, it tends to form laccolithic sills, near the base of the Weber (?) formation, which crosscut some of the overlying strata.

The most distinctive feature of the Lincoln porphyry is the presence of large, well-formed pink orthoclase crystals, whose length usually averages about 1 inch yet at places is as much as 4 inches. Their abundance varies, even in the same igneous body, but nowhere exceeds 10 percent of the rock by volume. They enclose smaller grains of biotite, quartz, and, less commonly, plagioclase. At some places large phenocrysts of quartz, not more than 1 inch in length, occur in addition to orthoclase. The remainder of the rock resembles the quartz monzonite porphyry and consists of small and medium-sized

31 Singewald, Q. D., op. cit. (Jour. Geology, vol. 40), pp. 23-25.

${ }^{32}$ Butler, B. S., Influence of the replaced rock on replacement minerals associated with ore deposits: Econ. Geology, vol. 27, pp. 1-24, 1932.

${ }^{33}$ Emmons, S. F., op. cit. (Mon. 12), pp. 328-330. 
phenocrysts of plagioclase, quartz, and biotite abundantly distributed in a light- to medium-gray, slightly greenish, dense groundmass. Originally, hornblende was probably a minor constituent at places. Where intensely altered the rock is bleached to a very light gray. Weathered surfaces are either light gray or rusty brown.

In many occurrences normal Lincoln porphyry grades rather abruptly near the margin into a facies that contains no large orthoclase crystals, very little quartz, and plagioclase crystals that are smaller than in the type rock. Moreover, this marginal facies is everywhere more intensely altered than the rest of the rock. The marginal facies is thought to be derived from early portions of the intruding magma that solidified before the arrival of later portions bearing the large intratelluric crystals. A concentration of large crystals in late portions of the magma could have been accomplished by more rapid movement of magma than of crystals, owing to a slight tendency toward crystal settling, during their upward migration. from the underlying reservoir.

Large orthoclase crystals seldom are seen under the microscope except in specially prepared thin sections. They are almost unaltered, yet appear somewhat cloudy. They contain unoriented inclusions of the other phenocrysts, especially biotite, and some contain graphically intergrown quartz. The Lincoln porphyry has a little more quartz and orthoclase in its groundmass and shows slightly less intense regional hydrothermal alteration than the quartz monzonite porphyry, but except for these differences and the presence of the large orthoclase crystals in the Lincoln porphyry, the two rocks are microscopically alike.

\section{STRUCTURE}

\section{REGIONAL STRUCTURE}

The regional dip of the stratified rocks in the Mosquito Range is eastward, away from the Sawatch uplift, but this dip is modified by folding and faulting. The most conspicuous folds are long and narrow and are associated with the major reverse faults. Each fault and fold may be considered to form a composite structure in which the early movement produced a fold, whereas the later movement produced a fault that was accompanied by additional drag of the beds along the fault. Folding of the more ordinary type is inconspicuous, as may be seen from plate 3 , and is represented by variations in strike and dip that produce structural terraces and plunging anticlinal or synclinal noses. Economically, the most important of these features are the terrace shown by the spacing of structure contours across Mount Bross and Mount Lincoln and the plunging anticline shown by the bend in structure contours of the same area.

The major faults on the east side of the Mosquito Range are shown on plates 1 and 3. The largest is the London fault, which, at least at 
London Mountain, is a reverse fault dipping steeply to the east. Associated with it is the London or Sheep Mountain anticline. The Cooper Gulch fault, likewise reverse, dips much less steeply and has smaller throw than the London fault; a small fold is associated with it. The Sherman fault, which is accompanied by a pronounced fold, is probably a reverse fault with east dip, though it is nowhere exposed, either at the surface or in mine workings. All available evidence indicates that most of the movement along the major faults took place prior to ore deposition, but that slight movements continued during and after ore deposition.

Minor faults, some auxiliary to major faults and others independent of them, are too abundant to be shown on small-scale maps, but a particularly large one is shown on plate 3 . Nevertheless they are of economic importance, as virtually all the ore bodies of the district are in or adjacent to minor faults.

Some additional explanation of the structure contours of plate 3 is necessary. The contours between the eastward-dipping London fault and the London syncline on Pennsylvania Mountain are drawn a little west of their true position; otherwise they would overlap the contours on beds east of the fault. Farther south no attempt has been made to sketch contours between the London fault and the syncline, because of the inadequacy of data. For the same reason, neither the surface nor the subsurface syncline west of the Sherman fault is shown. The intersection of the Cooper Gulch fault with the horizon that is contoured would be west of its surface trace as shown on the map.

\section{LONDON FAULT}

The London fault ranks next to the Mosquito fault as the second longest in the Mosquito Range. It has been traced southeastward from the Mosquito fault for more than 20 miles. It is associated with an asymmetric anticline whose steep west limb, which nowhere exceeds 2,000 feet in width, constitutes a disturbed belt in which the rocks have been sharply folded from their normal attitude and broken by innumerable auxiliary faults.

The fault, whose name is derived from London Mountain, was first described in the Leadville monograph, in 1886, by Emmons. $\mathrm{He}$ recognized its large displacement and its close association with the folds at Sheep Mountain and elsewhere. It was not recognized as a reverse fault, however, until nearly 30 years later, when Moore ${ }^{34}$ and Patton ${ }^{35}$ had the opportunity to study it in the underground workings of the London mine.

Except in the main gulches, the position of the trace of the London fault can be determined rather closely at most places by means of

84 Moore, C. J., op. cit., pp. 417-422.

ss Patton, H. B., Hoskin, A. J., and Butler, G. M., op. cit., pp. 102-114. 
exposures and prospect pits on each side. On account of a mantle of unconsolidated materials, however, outcrops of the fault are rare. One outcrop is on Sheep Mountain, between altitudes of 11,300 and 12,200 feet. There the west wall is greatly shattered porphyry, and the east wall alternately Parting quartzite and Dyer dolomite, for both the Dyer and the Leadville are irregularly thinned by shearing and stretching in the fault. From west to east the shear zone consists of about 5 feet of clay gouge containing crushed fragments of porphyry; 50 feet of coarse breccia composed of limestone, porphyry, and clay gouge; and 75 feet of irregularly silicified, broken limestone and limestone breccia. An outcrop of coarse silicified breccia composed chiefly of Weber (?) quartzite forms a small but conspicuous butte at the top of the north side of Pennsylvania Mountain and extends 500 feet vertically down the slope. The silicified breccia is flanked by and grades into unsilicified breccia, containing less quartzite, which is poorly exposed. A similar but less conspicuous outcrop of fault breccia occurs at the top of the south side of Pennsylvania Mountain. In places the width of the shear zone at Pennsylvania Mountain exceeds 100 feet. On London Mountain, just south of the point where the fault crosses the crest, fine-grained quartzite or chert crops out in the fault shear zone for a lateral distance of several hundred feet. At still another locality, on the south slope of a ridge that forms the divide between the two branches of Sacramento Creek, virtually no breccia exists, and so the exact position of the fault cannot be determined, in spite of excellent exposures of nearly vertical Weber (?) strata for more than 1,000 feet across the west limb of the fold. At all outcrops the fault has a steep dip, but neither the exact amount nor the direction can be determined.

Underground mine workings cut the London fault at several places. On London Mountain Paleozoic sedimentary rocks and intruded porphyry sills to the west are separated from pre-Cambrian rocks to the east by a shear zone 40 to 100 feet wide. Within the shear zone there are layers of highly crushed rock that alternate with thinner layers of nearly pure gouge. Locally crushed pre-Cambrian rocks occur next to the footwall. Slickensides reveal innumerable planes of slipping. The dip of the fault, as shown by observation and by projection in cross sections, ranges from $60^{\circ}$ to $80^{\circ}$ to the east. In the Berlin tunnel, which crosses the fault diagonally on the south side of Pennsylvania Mountain, the rocks are largely concealed by timber, yet it can be determined that the shear zone, 30 to 40 feet wide, contains much heavy gouge and that the Weber (?) rocks west of the fault and the pre-Cambrian rocks east of the fault are intensely shattered.

A significant structural feature is the regional southeasterly slope of the sedimentary strata along the fault, due primarily to divergence 
between the trend of the fault and the strike of the beds. The slope is not uniform, however, as may be seen from the structure contours of plate 3. In the anticline east of the fault the pitch north of Pennsylvania Mountain is unknown, because the sedimentary strata there have been entirely eroded. Across Pennsylvania Mountain the axis pitches rather steeply toward the north fork of Sacramento Creek, where it abruptly flattens. It continues with southeast pitch to a broad saddle at the south fork of Sacramento Creek, then rises very gently to a structural high on Sheep Mountain, beyond which it again pitches steeply southeast. In addition, there are local variations in pitch, some of which are suggested by bends in the structure contours.

The pitch of the axis of the syncline west of the fault, although complicated somewhat by faulting, also varies. It is moderate to the southeast from the crest of the range to New York Mountain, steep from that point to the crest of London Mountain, and thence gentle as far as Pennsylvania Mountain, where it again steepens. In this interval, moreover, the curve in the contours midway between the portals of the South London and London Extension mines suggests a local flattening. Southeast of Pennsylvania Mountain altitudes at the top of the Leadville limestone west of the fault are very uncertain. The most probable interpretation in the absence of subsurface data, however, is that the axis remains about level, at an altitude of about 9,000 feet, as far south as Sheep Mountain. Surface dips in the Weber (?) formation suggest a structural saddle approximately beneath the Mudsill mine, with a very slight northwest pitch from that point to Sheep Mountain, but owing to undeterminable variations in thickness of porphyry sills near the base of the Weber (?), it is impossible to determine how closely dips on beds overlying the porphyries reflect the structure of the pre-Pennsylvanian strata. Neither the subsurface position of the fault nor contours between the west wall of the fault and the syncline have been shown on plate 3 .

In addition to variations in the pitch of the anticlinal and synclinal axes, there are even more decided irregularities in the pitch of the intersection of the fault with the top of the Leadville limestone on each side. These irregularities are due chiefly to differences in the relative distance of the fault from the axes. For example, at the crest of London Mountain the fault is relatively far from the syncline, so that the dip, which becomes increasingly steep away from the axis, carries the top of the Leadville limestone to a high altitude before it is cut off by the fault. Farther south the fault is closer to the syncline, and so the Leadville limestone is cut off at a much lower altitude. Still farther south, toward South Mosquito Creek, the fault trends away from the synclinal axis, and the Leadville limestone again rises higher, in spite of the southeast pitch of 
the syncline itself. Analogous but less pronounced features occur east of the fault.

The best data concerning displacement are obtained from the north side of Pennsylvania Mountain, where the total apparent throwthe vertical component of the distance between the anticlinal and synclinal axes-on the top of the Leadville limestone is approximately 3,000 feet, of which about 1,400 feet is due to folding and 1,600 feet to actual displacement. Farther north the throw cannot be calculated, because the sedimentary strata have been entireiy eroded east of the fault. South of Pennsylvania Mountain the Weber (?) strata west of the fault include no recognizable beds whose stratigraphic distance above the Leadville limestone is known. By projecting the Leadville limestone underground on the basis of surface dips, with allowance for thinning of porphyries near the base of the Weber (?), the total apparent throw at Fourmile Gulch may be calculated as about 3,600 feet, though the limit of error may be about 1,000 feet. Outcrops on cliffs on each side of the gulch show that at least 800 feet of the apparent throw is due to folding and at least 1,000 feet to displacement. As the lower formations, where they disappear beneath the glacial drift in Fourmile Gulch, dip nearly parallel to the fault, only half of the total apparent throw was assigned to displacement in constructing a geologic cross section. (See pl. 2.) Between Fourmile Gulch and Pennsylvania Mountain the calculations are still more conjectural but suggest that the total apparent throw remains about the same as at Fourmile Gulch, and so the actual displacement probably remains nearly constant also. Subsurface data, however, are necessary for precise information. South of Fourmile Gulch the fault is cut by the Barcoe tunnel (see fig. 11). The displacement along the London fault doubtless had, in addition to the vertical component, a horizontal component parallel to the fault, but data are not available to calculate its magnitude.

A tremendous number of auxiliary faults, which render the structure exceedingly complicated in detail, undoubtedly occur on each side of the London fault throughout its length. Exposures are not good enough, however, to disclose more than a few of these auxiliary faults. Hence, an adequate study of them can be made only by detailed mapping of the extensive mine workings on the west side of the fault at London Mountain. There, the greater number of the auxiliary faults strike more or less parallel to the London fault but dip to the southwest; many, however; strike northwest and dip northeast, and many others are transverse. Some terminate against the London fault; others displace it. Movement on most of the auxiliary faults, even on many that displace the London fault, began contemporaneously with that on the London fault but was long continued. At several places on the surface moderately large trans- 


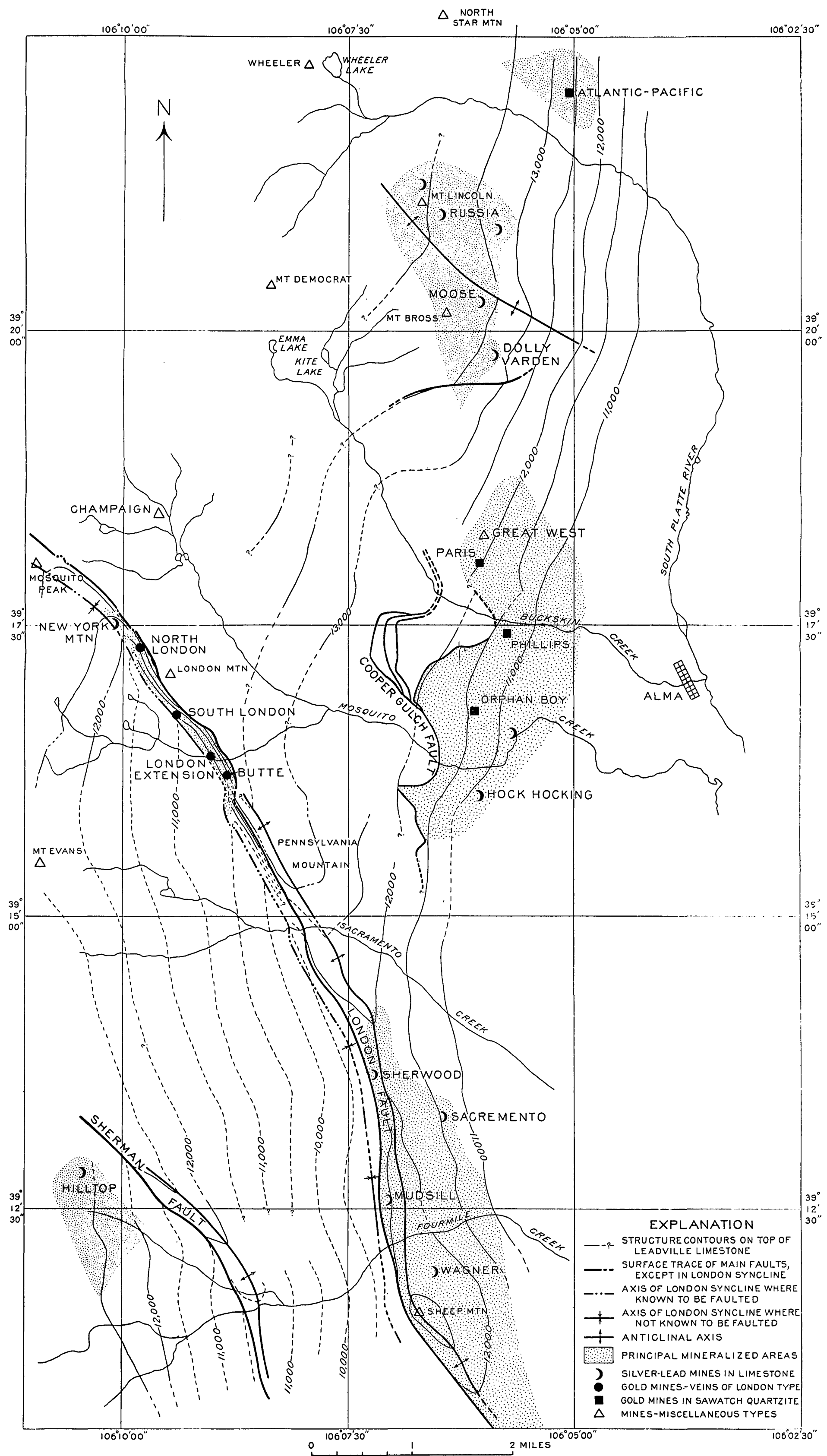

GENERALIZED STRUCTURE MAP OF AREA NEAR THE LONDON FAULT, SHOWING RELATION OF ORE DEPOSITS TO MAJOR STRUCTURE. 


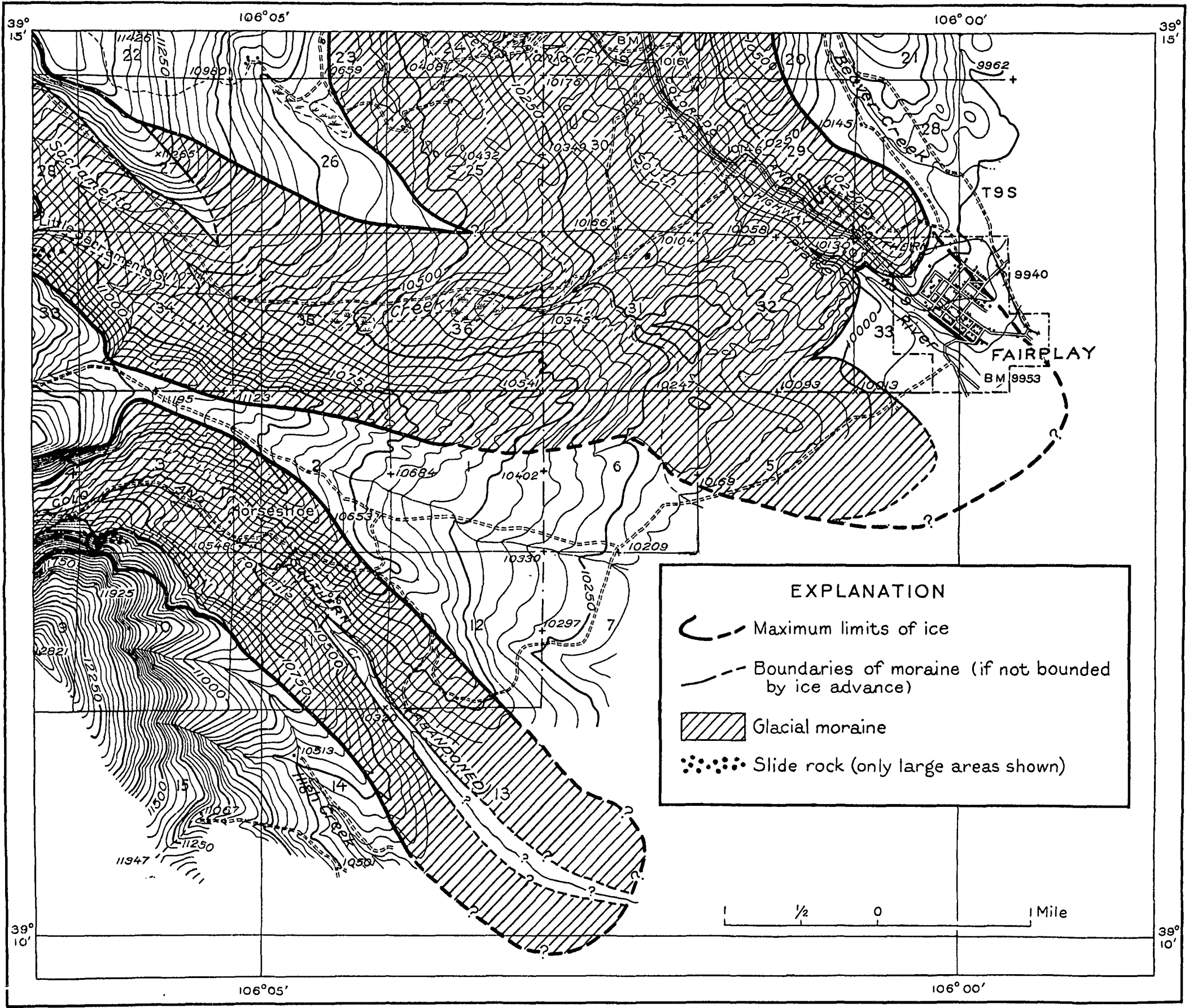

GLACIAL MAP OF AREA WEST OF FAIRPLAY.

By Q. D. Singewald. 
verse faults are suggested by apparent offset of the London fault for distances not exceeding 400 feet, yet none can be actually seen. Probably the most extensive belt of inferred transverse faulting occurs between the London-Butte mine and the center of Pennsylvania Mountain.

Structural data in addition to those discussed in the text may be gleaned from the cross sections of plate 2. In order to construct the sections from Pennsylvania Mountain southward, the London fault was assumed to dip steeply eastward, as at London Mountain, and the axial plane of the syncline was assumed to be parallel to the fault. Neither assumption, however, can be proved from surface data. Moreover, the dip of the Sherman fault and the position of the syncline west of it are not known.

\section{QUATERNARY GEOLOGY}

Economic importance.-Long-continued erosion preceuing Pleistocene glaciation developed a mature topography whose drainage pattern in general was the same as now, except that the valleys were comparatively shallow. Glacial erosion in the uplands and deposition in the lowlands greatly modified this topography at places, especially near the crest of the range and in the valleys. The changes have considerable economic importance, because nearly all oxidation and enrichment of the ore deposits is preglacial in age and therefore is related to the preglacial topography. The bottom of the oxidized zone is very irregular in detail, but at places it extends as deep as 1,000 feet below the preglacial surface. Loughlin ${ }^{36}$ states that the variations in depth below the preglacial surface were caused by variations in geologic structure, in the lithologic character of the country rock, and in the form and position of the ore bodies.

Areas affected.-The glacial geology of the Alma-Horseshoe district is shown on plate 4 . Plate 5 is a similar map of the area west of Fairplay. As shown by Capps, ${ }^{37}$ who studied both slopes of the Mosquito Range, there were at least two stages of Pleistocene glaciation, separated by a very long interglacial stage. As the early glaciers occupied essentially the same positions as the last one and as their effects were cumulative, these areas are the only ones in which the preglacial topography has been greatly eroded. Deposition took place (1) in the areas where glacial deposits are mapped by Capps and (2) in South Park, where a considerable thickness of alluvium collected from the glacial outwash.

Postglacial erosion has been slight, and the only noteworthy postglacial deposits are the talus accumulations at or near the base of high cliffs.

30 Emmons, S. F., Irving, J. D., and Loughlin, G. F., op. cit., p. 254.

37 Capps, S. R., Pleistocene geology of the Leadville quadrangle, Colo.: U. S. Geol. Survey Bull. 386, pp. 8-25, 80-89, and pl. 1, 1909.

$156659-40-3$ 


\section{ORE DEPOSITS}

\section{REGIONAL RELATIONS}

A brief statement concerning the distribution, character, geologic relations, and mode of origin of the principal ore deposits in the Alma district and a comparison of these deposits with those on the west side of the Mosquito Range will enable the reader to understand better the significance of the specific descriptions that follow, for the ore occurrences along the London fault constitute only a part of the larger group.

\section{DEPOSITS IN THE ALMA DISTRICT}

\section{DISTRIBUTION}

Well over 90 percent of all the production from the east side of the Mosquito Range has come from a northeasterly belt that roughly coincides with but extends somewhat south of the belt of dikes and stocks mentioned on page 16. Away from this belt the deposits in general decrease in both number and size, although valuable deposits have been found outside of it. At least 95 percent of the production within the belt has come from deposits restricted to rather well defined areas located where the northeasterly belt is crossed by major structural features trending north to northwest. As may be seen in plate 3, the deposits of London Mountain and New York Mountain occur on the footwall side and within a few hundred feet of the London fault. The mines from the Hock Hocking to the Great West are on the hanging-wall side and within 4,000 feet of the uppermost branch of the Cooper Gulch fault, close to the point where the branch dies out; the different positions of the ores with respect to these two reverse faults may be attributed to the large amount of clay gouge in the London fault and the very small amount in the Cooper Gulch fault, as is explained in the discussion of the origin of the deposits. The Dolly Varden, Moose, Russia, and other deposits are on a structural terrace, trending northward, that undoubtedly is part of the same tectonic unit as the Cooper Gulch fault, and their position on this terrace apparently was influenced by the anticlinal nose plunging southeastward between Mount Lincoln and Mount Bross. On the other hand, a relatively unimportant mineralized area at North Star Mountain, as well as numerous scattered small deposits, most of which are not shown on plate 3 , are not related to any major structural features trending north to northwest.

Although major structural features have controlled the regional distribution of the mineralization, the individual ore bodies without exception have been localized by premineral minor faults. As most of the minor faults die out within short distances, horizontally and 
vertically, large ore shoots are uncommon; yet within a mineralized area a series of discontinuous ore bodies, each along a different fissure, may continue for a considerable distance. The most continuous group of veins in the district is that along minor faults, auxiliary to the London fault, in the porphyry zone of the London mine.

\section{ClaSSIFICATION}

As measured by value of past production, the most important classes of ore bodies in the Alma district are (1) gold veins of the London type in or adjoining porphyry sills near the base of the Weber (?) formation, (2) silver-lead deposits in limestones, and (3) gold deposits in the quartzites of the Sawatch formation. Other classes exist but they are of minor economic importance. This classification reveals the significant fact that the gold ores are largely confined to siliceous rocks and the silver-lead ores to calcareous rocks.

\section{GOLD VEINS OF THE LONDON TYPE}

In the vicinity of London Mountain gold-bearing quartz veins containing subordinate amounts of pyrite, sphalerite, galena, and chalcopyrite occur principally along faults that dip southwestward at a slightly smaller angle than the dip of the strata, which are sharply upturned against the London fault. The stratigraphic position of most of the ore is in or adjoining porphyry sills near the base of the Weber (?) formation.

\section{SILVER-LEAD DEPOSITS IN IIMESTONES}

Most of the silver-lead production has come from ore bodies that have been formed by replacement of shattered beds close to minor faults in the Leadville limestone. A typical deposit of this type was described in an earlier paper. ${ }^{38}$ The most abundant hypogene gangue mineral is an iron-bearing dolomite (table 4) which at most mines is accompanied by considerable quantities of barite and a little quartz. Sphalerite and galena are abundant, pyrite is fairly common, and chalcopyrite and either tetrahedrite or freibergite occur in small amounts. Freibergite seems to account for most of the silver of the high-grade hypogene ores. The sphalerite is dark-colored in spite of its fairly low iron content. Almost all the deposits are partly oxidized and slightly enriched; a few contain noteworthy amounts of supergene native silver.

Less important commercially than the deposits replacing limestone beds but similar to them in mineralogy are replacement veins along minor faults in the Leadville and Manitou limestones.

88 Singewald, Q. D., and Butler, B. S., Preliminary report on the geology of Mount Lincoln and the Russia mine, Park County, Colo.: Colorado Sci. Soc. Proc., vol. 12, pp. 389-406, 1931. 
TABLE 4.-Analyses of gangue carbonates, Alma district, Colorado

\begin{tabular}{|c|c|c|c|c|c|c|c|}
\hline . & 1 & 2 & 3 & & 1 & 2 & 3 \\
\hline \multirow{2}{*}{$\begin{array}{l}\mathrm{H}_{2} \mathrm{O} \\
\mathrm{FeO} \\
\mathrm{MnO} \\
\mathrm{CaO} \\
\mathrm{MgO}\end{array}$} & \multirow{2}{*}{$\begin{array}{r}1.22 \\
1.87 \\
52.18 \\
.26\end{array}$} & \multirow{2}{*}{$\begin{array}{r}1.8 \\
.4 \\
26.7 \\
17.1\end{array}$} & \multirow{2}{*}{$\begin{array}{r}0,22 \\
2.12 \\
1.00 \\
29.90 \\
19.10\end{array}$} & \multirow[t]{2}{*}{$\begin{array}{l}\mathrm{CO}_{2} \\
\text { Insoluble in } \mathrm{HCl}\end{array}$} & $\begin{array}{l}43.02 \\
(1)\end{array}$ & $\begin{array}{r}41.8 \\
212.1\end{array}$ & $\begin{array}{r}45,34 \\
2.36\end{array}$ \\
\hline & & & & & 98.55 & 99.9 & 100.04 \\
\hline
\end{tabular}

1 Insoluble residue not weighed; examined under the microscope and found to be sericite, carbonaceous material, and quartz.

2 Examined under the microscope and found to be quartz.

1. London mine. R. E. Stevens, analyst.

2. Russia mine. J. J. Fahey, analyst.

3. Orphan Boy mine. J. G. Fairchild, analyst.

GOLD DEPOSITS IN THE QUARTZITES OF THE SAWATCH FORMATION

The group of mines extending from the Brownlow to the Paris and a few others yielded gold ore containing various amounts of silver from veins along minor faults in the quartzite beds of the Sawatch formation. The veins are productive only at certain favorable horizons in the middle and upper parts of these beds, where thin ore shoots have been formed by replacement of the wall rock for several feet from the fault. Beds containing considerable quantities of carbonate cement, which could be more easily attacked than the characteristic siliceous cement, have served to localize most of the shoots. This is probably true even at places where the ore occurs beneath a porphyry sill that may have acted as a dam to the solutions, for ore does not underlie all sills cut by the same fissure nor does it necessarily underlie the lowest sill.

The hypogene sulphide minerals, named in their order of abundance, are pyrite, sphalerite, galena, and chalcopyrite. There is a distinct tendency for pyrite, which is the oldest, to be segregated from the other three, although they all are intergrown at places. The gold is associated with the sphalerite, galena, and chalcopyrite. Dolomite (see table 4) containing small quantities of iron and manganese is the most abundant gangue mineral. It has healed cracks in the sulphide minerals in such a manner as to give the ore a brecciated appearance, and in many places it has extensively replaced the quartzite wall rock; large masses invariably contain numerous vugs. Quartz is abundant locally. Some of it formed late, as it coats vugs in the dolomite.

All the deposits are at least partly oxidized, and in some of the mines the ore has been thoroughly leached to a limonitic clay. This has caused the gold to be enriched by removal of other constituents, and it is doubtful whether many of the deposits could have been worked profitably if they had not been altered. However, as most of the veins are very narrow and unproductive except at the favorable horizons, it is unlikely that enough gold could have been derived from the material above the present ore shoots for them to have been notably enriched through addition of gold by descending waters. 


\section{MUTUAL RELATIONS OF THE CLASSES}

As all the deposits have the same age relations to faults and igneous intrusions (see fig. 2), there must have been but one period of ore deposition.

Silver-lead deposits were formed through marginal facies of mineralization with respect to both classes of gold deposits, but the two gold classes have not been mined in proximity, and their relations to each other are not known directly. Evidence presented on page 62 indicates that the silver-lead ores on New York Mountain are marginal to the gold veins of London Mountain. The silver-lead veins of the Hock Hocking mine and the unimportant replacement deposits at the

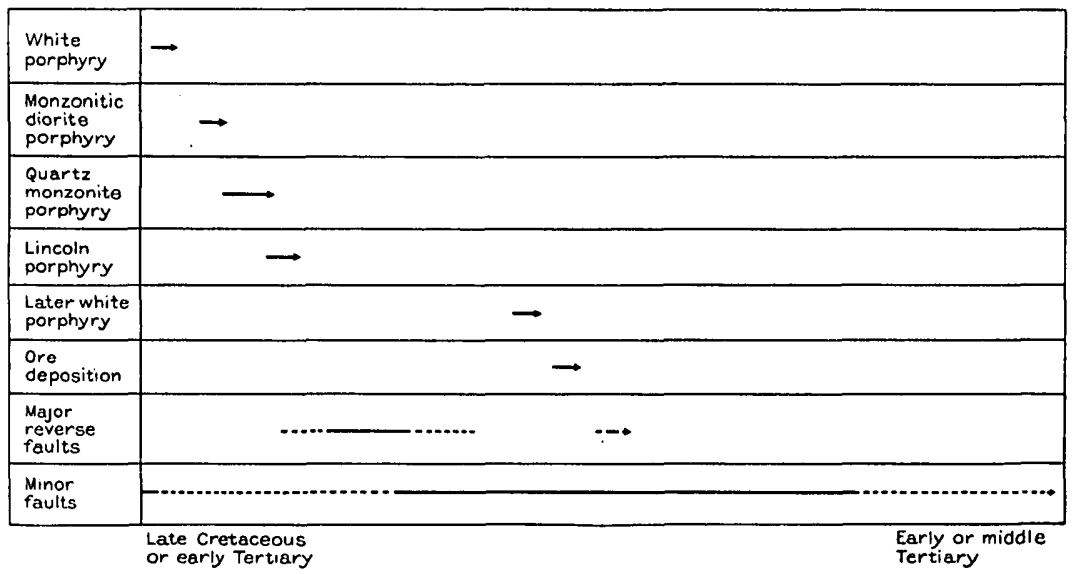

FIGURE 2.-Age of ore deposits in relation to faulting and igneous intrusion. Length and position of arrows indicate relative time.

Mosquito Gulch mine and on the Red Cross claims are farther from the Cooper Gulch fault than the gold veins in the Brownlow, Orphan Boy, Phillips, Paris, and other mines, and their positions favor the interpretation that the silver-lead ores are marginal; moreover, exploration work in the Hock Hocking mine has shown that the silverlead veins do not grade downward into gold ore where the fissures cut the quartzites. However, the silver-lead deposits that are definitely marginal to gold deposits exhibit effects of weaker mineralization than the typical replacement deposits in limestone in the Dolly Varden. Moose, and Russia mines, none of which are near any known gold deposits of importance. These relations as a whole, therefore, suggest that the large silver-lead deposits did not form directly above large gold deposits.

\section{ORE FACIES AT LFADVHLLE}

In describing the hypogene ores of the Leadville district, Loughlin ${ }^{39}$ pointed out the essentially zonal distribution of typical mesothermal (medium-temperature) deposits-including (1) veins and stockworks

3 Emmons, S. F., Irving, J. D., and Loughlin, G. F., op. cit., pp. 177-208. 
and (2) blanket ore bodies-around the hypothermal (high-temperature) or contact-metamorphic deposits in the Breece Hill area. Recently Behre ${ }^{40}$ described a more distant facies found outside of the main Leadville district.

Loughlin has kindly written the following summary of the zonal relations that he and Behre ${ }^{41}$ determined for the ores on the west side of the Mosquito Range:

The ores of the Leadville district, according to data in the Leadville report, may be grouped into four distinct zones and a possible fifth zone with respect to the Breece Hill stock. Deposits of the first or innermost zone, close by the stock, contain magnetite, specularite, and silicates. The magnetite especially contains interstitial manganosiderite, which began to form at the end of magnetite deposition and marks a transition into the second and commercially most important zone. This second zone, most extensively developed in the limestones west of the stock, contains large quantities of manganosiderite, which forms casings around the large replacement deposits of sulphides and is partly replaced by sulphides. As distance from the main feeding fissures increases, transition into the third zone is expressed by the disappearance of the manganosiderite casing and the appearance of quartz casings in their stead. The abundance and proportions of the sulphides, however, do not appreciably change, and the third zone is about as important commercially as the second zone. Pyrite is by far the dominant sulphide in both zones, iron-rich zinc blende (marmatite) is the next in abundance, galena is third, and chalcopyrite is very scarce. Silver ordinarily amounts to a few ounces to the ton, and gold is negligible, but locally the ore bodies have been reopened and enriched by small deposits containing bismuth and silver sulphides, chalcopyrite, and gold.

On the east side of the stock, where siliceous rocks (quartzite, "Weber grits," and porphyries) predominate, manganosiderite is not prominent, and the second zone is therefore not clearly defined except as a mere fringe to the magnetite deposits. The deposits are mostly quartz-sulphide veins that locally expand into replacement deposits where they cut limestones. They contain the same ore and gangue minerals as the replacement ores with quartz casings in the third zone, but their contents of chalcopyrite and gold are relatively high. These two minerals, although deposited later than the quartz, pyrite, and zinc blende, evidently prefer pyritic veins in siliceous rocks, regardless of their areal position in the zonal scheme. Some of these pyritic veins cut the magnetite deposits of the first or innermost zone and give the erroneous impression that gold occurs mainly in the high-temperature ore of the inner zone, whereas it really occurs in the moderate-temperature ore of the third zone.

Transition from the third to the fourth zone is marked by the appearance of abundant barite, which with quartz constitutes the principal gangue and in places is accompanied by such carbonates as ferruginous dolomite and rhodochrosite. Zinc blende in the fourth zone is relatively low in iron, and the ratio of galena to blende is probably higher than in the second and third zones; but so much of the ore mined has been partly or completely oxidized that this difference is not clearly defined. Tetrahedrite or freibergite and tennantite are also present, at least in small amount, but their relative proportions also have been obscured by oxidation. They account for a characteristically high silver

\footnotetext{
10 Behre, C. H., Jr., Distant facies of ore deposits at Leadville, Colo. [paper read before the Society of Economic Geologists, Dec. 30, 1831].

11 Behre, C. H., Jr., and Loughlin, G. F., Zoning of ore deposits in and adjoining the Leadville district, Colo.: Econ. Geology, vol. 29, pp. 215-254, 1934.
} 
content. The fourth zone may be regarded as ordinarily the outer or marginal zone of the well-defined area of ore deposition.

A fifth, still more remote zone, however, has also been tentatively recognized, in which neither barite nor quartz is present in noteworthy quantity and dolomite is the principal gangue mineral. The zinc blende and galena have essentially the same character and ratio as in the fourth zone, but the silver content is low. Deposits of this variety have been recognized only at Weston Pass and are too far from deposits of the fourth zone for their zonal relations to be more than tentatively recognized.

\section{RELATIONS OF THE ORES AT ALMA TO THOSE AT LEADVILLE}

The gold veins of the London type are similar in many respects to the "mixed siliceous sulphide" veins at Leadville and therefore may be classified with the typical mesothermal facies of the third zone.

The silver-lead deposits in the Alma district contain iron-bearing dolomite as the chief gangue constituent and small quantities of either tetrahedrite or freibergite as an ore mineral but in other respects are very similar to the ores of the marginal or fourth zone at Leadville.

The gold deposits in the quartzites of the Sawatch formation, however, cannot be readily classified with those of any of the described zones at Leadville. The small size and narrow stratigraphic range of the ore shoots and the presence of large quantities of dolomite, which has a low iron and very low manganese content, are features suggesting the marginal facies. On the other hand, the abundance of pyrite, the dark color of the sphalerite, and the absence of barite are suggestive of the typical mesothermal facies of the third zone. Therefore it seems probable that the deposits represent a variety of the mesothermal facies derived from a much smaller supply of ore solutions than the larger and more persistent veins at Leadville. It is possible that, owing to the small supply, the solutions cooled rather rapidly, so that before the mineralization ceased they had reached the temperature at which the iron- and manganesebearing dolomite precipitates; but it is also possible that the dolomite, which has healed cracks in the sulphide minerals, represents material deposited by solutions of fairly low temperature in reopened veins composed of earlier medium-temperature minerals.

\section{LOCAI CENTERS OF MINERALIZATION AT ALMA}

It is apparent from the foregoing statements that nearly all the important deposits in the Alma district are within elongated areas (see pl. 3) which are closely associated with major reverse faults of north to northwest trend that cross a northeasterly belt of general mineralization. The deposits in each of these areas show a zonal arrangement which suggests that each area contains a local center ${ }^{42}$ or focus of mineralization. Evidence is presented later in this

"For a more comprehensive discussion of this subject see Singewald, Q. D., and Butler, B. S., Suggestions for prospecting in the Alma district, Colo.: Colorado Sci. Soc. Proc., vol. 13, no. 4, pp. 110-114, 1933. 
paper to show that small silver-lead deposits in limestone constitute a facies marginal to the gold veins at London Mountain, the strongest local center in the district. The marginal relations of the small silver-lead deposits in the lower parts of Mosquito and Buckskin Gulches to the gold and gold-silver deposits of the Orphan Boy, Phillips, and Paris mines indicate the existence of a local center under the lower slope of Loveland Mountain, much weaker than that at London Mountain. The location and mineral composition of the important silver-lead deposits of the Dolly Varden, Moose, Russia, and other mines are consistent with the idea that these deposits are marginal to a center at the Buckskin Gulch stock. Except for some small magnetite deposits, of no commercial value, in the pre-Cambrian rocks near the stock, the central zones of this area are not represented, but this is doubtless because the beds favorable to ore deposition are now eroded in the vicinity of the stock.

A fourth, relatively unimportant center, which is not associated with a major reverse fault but which lies in the northeasterly belt of general mineralization may be under North Star Mountain, where, according to J. W. Vanderwilt, ${ }^{43}$ there are some irregular deposits containing magnetite, specularite, and pyrrhotite, and some veins composed of coarsely crystalline quartz, pyrite, and hübneriteminerals suggesting deposition at moderately high to high temperatures. The Jower-temperature types are not well represented around this center, although they may have been present in the sedimentary rocks that formerly overlay the area.

\section{ORIGIN OF ORES AT AIMA}

Loughlin ${ }^{44}$ has presented strong evidence in favor of an igneous origin for the ore deposits throughout the Mosquito Range. The absence of high-temperature minerals except in minor amounts near the Buckskin Gulch stock and at North Star Mountain and the presence of intermediate- and low-temperature minerals in the deposits of the Alma district suggest that the source of the ore-forming solutions lay at a considerable depth below the present surface. The source was too deep to be tapped by the minor faults along which the ore bodies are localized, for with few exceptions these faults die out within short distances; hence, the solutions must have worked their way toward the surface by ascending as far as possible along similar faults at depth, then breaking across to others. The ensuing mineralization would be scattered and unimportant except where the solutions were concentrated into trunk channels-long and deep zones in which fissures are closely spaced and connected-such as along the major reverse faults. A strong tendency to migrate vertically,

${ }^{43}$ Personal communication.

4 Emmons, S. F., Irving, J. D., and Loughlin, G. F., op. cit. (Prof. Paper 148), pp. 209-210. 
especially in the vicinity of low-angle faults, forced the solutions to the hanging-wall side as far above the reverse fault as they could find easily accessible openings, provided they did not encounter impervious clay gouge in the fault. The ore deposits formed under those conditions are scattered over an area extending for some distance away from the main fault. On the other hand, large quantities of impervious clay gouge, as along the London fault, served as a barrier to keep the solutions on the footwall side, so that the resulting ore deposits are concentrated close to the main fault. Under either condition the solutions could ascend with comparative ease until they reached plastic and impervious rocks, such as the shales in the lower part of the Weber (?) formation, in which the fissures were tight. At such a place they became temporarily stagnant or extended up the dip along the bedding, and ore deposition ensued before they ascended much farther. The physico-chemical action of the solutions must have been very similar to the action described by Loughlin ${ }^{45}$ for the Leadville district and by Behre ${ }^{46}$ for the outlying regions.

Although the main reason for the distribution of ore deposits along reverse faults is that the fault zones served as trunk channels, another factor may have contributed to some extent. In discussing the regional relations of the Tertiary (?) plutonic igneous rocks in central Colorado, Crawford ${ }^{47}$ pointed out that the major reverse faults are younger than most of the intrusive porphyries but older than the stocks. Several occurrences of plutonic rocks apparently were localized by the faults, a relation which the writers found to exist for the Buckskin Gulch stock ${ }^{48}$ in the Alma district. Hence, protuberances that have not been exposed by erosion may have formed along the faults below the surface, both along the crest and on the sides of the batholith whose existence is indicated by the dikes and stocks, and the principal centers of mineralization may be closely related to these protuberances.

\section{THE LONDON VEIN SYSTEM}

\section{LOCATION}

The London (including the London Extension, Soutb London, North London), American, London-Butte, and other properties of the London vein system are near the head of Mosquito Gulch, on London Mountain, and in South Mosquito Gulch. The London Extension and North London camps, on opposite sides of the mountain, are about 6 and 7 miles, respectively, from Alma Junction, which was the terminal of the Fairplay-Alma branch of the Colorado \&

\footnotetext{
is Emmons, S. F., Irving, J. D., and Loughlin, G. F., op. cit., pp. 210-219.

4 Behre, C. H., Jr., op. cit.

"Crawford, R. D., A contribution to the Igneous geology of central Colorado: Am. Jour. Sci., 5th ser., vol. 7, pp. 367-375, 1924.

4s Singewald, Q. D., Igneous history of the Buckskin Gulch stock, Colorado: Am. Jour. Sci., 5th ser., vol. 24, p. $55,1932$.
} 
Southern narrow-gage railway, now abandoned. The camps are connected with Alma Junction by a highway with moderate grades. Ore is hauled to the railway by both trucks and teams.

\section{LONDON MINE 48}

\section{HISTORY AND PRODUCTION}

Moore $^{50}$ gives the following statements regarding history and production:

In 1873 float and occasional outcrops of the London vein were discovered, but the mine was not definitely located and opened until 2 years later. From 1875 the London mine was worked almost continuously until 1911, when the force was reduced to a few men.

Mr. Gummer's records show the production from the London vein from 1895 to 1910 , inclusive, to have been 52,588 net tons, yielding $\$ 2,018,920.10$; thus the average net value was $\$ 38.46$ per ton after deducting haulage, freight, and treatment charges. This production may be credited approximately as follows: From 1895 to 1907 , inclusive, the stopes above the Vienna (North London) level yielded 17,355 tons, valued at $\$ 516,096$ net; from 1905 to 1910 , inclusive, the stopes between the South London and Vienna (North London) levels and the south winze (now the 4 th level on the Big raise) yielded 35,133 tons, valued at $\$ 1,502,824$. The mean assay of 2,000 tons was 2.895 ounces of gold, 2.585 ounces of silver, 4.13 percent of lead; the mean analysis derived from smelter returns was 4.13 percent of $\mathrm{Pb}, 2.66$ percent of $\mathrm{Zn}, 4.85$ percent of $\mathrm{Fe}, 6.11$ percent of $\mathrm{S}$, and 76.80 percent of $\mathrm{Si}$-total 94.55 percent.

The total gross production of the London mine until 1911, inclusive, was about $\$ 5,000,000$. About 90 percent of this came from the London vein, and most of the balance from the McDonald vein.

Charles W. Henderson, of the Bureau of Mines, has supplied the following table taken from the records of the Geological Survey and the Bureau of Mines showing the production from 1908 to 1931. Thus the total gross production to 1931 , inclusive, is nearly $\$ 8,000,000$.

TABLE 5.-Production of London mine, 1901-31

\begin{tabular}{|c|c|c|c|c|}
\hline , & $\begin{array}{c}\text { Gold } \\
\text { (ounces) }\end{array}$ & $\begin{array}{c}\text { Silver } \\
\text { (ounces) }\end{array}$ & $\begin{array}{c}\text { Lead } \\
\text { recovered } \\
\text { (pounds) }\end{array}$ & $\begin{array}{l}\text { Copper } \\
\text { recovered } \\
\text { (pounds) }\end{array}$ \\
\hline 1901 & $\begin{array}{r}7,717.60 \\
7,740.07 \\
8,018.20 \\
15,009.22 \\
16,961.39 \\
22,978.61 \\
18,580.16 \\
24,459.62 \\
10,536.28 \\
799.84 \\
1,944.76 \\
992.71 \\
1,629.24 \\
6,743.27\end{array}$ & $\begin{array}{r}7,016.00 \\
7,467.00 \\
138,428.00 \\
14,142.00 \\
15,527.00 \\
21,153.00 \\
18,580.00 \\
19,267.00 \\
10,063.00 \\
706.00 \\
1,711.00 \\
949.00 \\
1,445.00 \\
5,311.00\end{array}$ & $\begin{array}{r}433,277.00 \\
416,912.00 \\
762,000.00 \\
445,935.00 \\
447,674.00 \\
293,451.00 \\
21,015.00 \\
61,355.00 \\
34,826.00 \\
38,402.00 \\
, 180,367.00\end{array}$ & $\begin{array}{r} \\
39,362,00 \\
32,702.00 \\
2,599.00 \\
5,017.00 \\
2,004.00 \\
2,317.00 \\
13,765.00\end{array}$ \\
\hline
\end{tabular}

See footnotes at end of table.

${ }^{9}$ In describing the geology of the London mine use was made of a private report by the late Charles $\mathrm{J}$. Moore, and of information furnished by S. J. Gately and F'orbes Rickard.

${ }_{50}$ Moore, C. J., op. cit., pp. 415-427; and also a private report to the London Co., dated March 1912. 
TABLE 5.-Production of London mine, 1901-\$1-Continued

\begin{tabular}{|c|c|c|c|c|}
\hline & $\begin{array}{c}\text { Gold } \\
\text { (ounces) }\end{array}$ & $\begin{array}{c}\text { Silver } \\
\text { (ounces) }\end{array}$ & $\begin{array}{l}\text { Lead } \\
\text { recovered } \\
\text { (pounds) }\end{array}$ & $\begin{array}{l}\text { Copper } \\
\text { recovered } \\
\text { (pounds) }\end{array}$ \\
\hline 191610 & $\begin{array}{r}10,784.59 \\
5,153.38 \\
2,989.09 \\
5,958.45 \\
6,735.82 \\
1,907.23 \\
1,972.71 \\
486.00 \\
1,058.77 \\
1,354.31 \\
1,744.37 \\
1,842.17 \\
12,288.27 \\
9,848.57 \\
22,595.07 \\
32,443.30\end{array}$ & $\begin{array}{r}10,039.00 \\
5,678.00 \\
3,301.00 \\
5,383.00 \\
6,579.00 \\
1,501.00 \\
1,298.00 \\
271.00 \\
1,490.00 \\
832.00 \\
1,079.00 \\
917.00 \\
4,995.00 \\
5,786.00 \\
11,712.00 \\
13,698.00\end{array}$ & $\begin{array}{r}320,545.00 \\
212,716.00 \\
132,642.00 \\
172,856.00 \\
176,014.00 \\
40,304.00 \\
39,422.00 \\
7,746.00 \\
34,520.00 \\
37,016.00 \\
42,400.00 \\
22,809.00 \\
129,931.00 \\
141,300.00 \\
2388,607.00 \\
2845,683.00\end{array}$ & $\begin{array}{r}19,033.00 \\
10,013.00 \\
7,359.00 \\
12,144.00 \\
8,894.00 \\
4,085.00 \\
3,135.00 \\
521.00 \\
255.00 \\
1,150.00 \\
137.00 \\
278.00 \\
750.00 \\
\\
\end{array}$ \\
\hline Total 1901-31 & $263,273.07$ & $237,178.00$ & 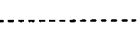 & $\ldots$ \\
\hline
\end{tabular}

1 Estimated.

2 Gross.

\section{GEOLOGIC MAP}

The underground map of the London mine (pls. 6-8) shows the detailed geology in all the workings accessible in 1931. Everywhere except in part of the North London level, where information was taken from a map prepared by Frank A. Aicher, the geology is indicated as it was mapped by the writers. Of the small workings included on the same map with the London, the Havighorst tunnel was mapped by the writers, although use was made of a map by $\mathrm{Mr}$. Aicher. The geology of the Ophir and Mosher workings was mapped by the writers and plotted on base maps furnished by the owners. The geologic map of the American mine was made by Mr. Aicher, who kindly permitted its publication.

\section{ROCKS}

Pre-Cambrian rocks.-The lower or Big London tunnel cuts preCambrian granite, injection gneiss, schist, and pegmatite on the east side of the London fault. (See fig. 3.) At a few other places workings that extend to the fault from the west side cut pre-Cambrian rocks in the fault zone.

Paleozoic sedimentary rocks.-The sedimentary rocks are eroded from the east side of the London fault north of Pennsylvania Mountain. In the immediate vicinity of the mine the oldest rocks exposed on the surface west of the fault belong to the Manitou limestone. The mine workings cut the Leadville limestone and the lower part of the Weber (?) formation.

Tertiary (?) igneous rocks.-Sills of White porphyry and quartz monzonite porphyry are exposed in the vicinity of the mine and are cut by the mine workings. Most of these are in the Weber (?) formation, but others are found locally at lower horizons. Away from 
the veins both porphyries exhibit their characteristic end-phase hydrothermal alteration. In the vicinity of the veins, however, the porphyries show still more intense hydrothermal alteration, so that determination of the type of rock is sometimes difficult. Nevertheless, fairly numerous outlines of former phenocrysts in the quartz monzo-

\begin{tabular}{|c|c|c|}
\hline & TYPE OF ROCK & THICKNESS \\
\hline 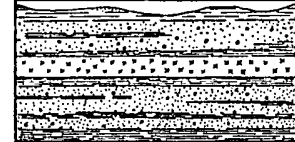 & $\begin{array}{l}\text { Weber (?) formation, with several } \\
\text { quartz monzonite porphyry sills }\end{array}$ & $700^{\prime} \pm$ \\
\hline 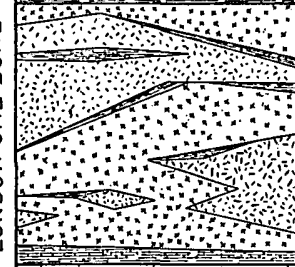 & $\begin{array}{l}\text { "PORPHYRY ZONE" } \\
\text { Interfingerings sills of white porphyry } \\
\text { and quartz monzonite porphyry, with } \\
\text { lenses of Weber, (?) formation. Almost } \\
\text { everywhere a 10'to } 20 \text { 'layer of Weber (?) } \\
\text { shale, quartzite, and locally limestone } \\
\text { occurs at the base }\end{array}$ & $175^{\prime}-275^{\prime}$ \\
\hline 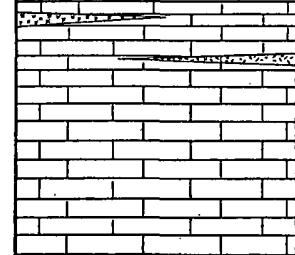 & $\begin{array}{l}\text { Leadville limestone and Dyer dolomite } \\
\text { member of Chaffee formation, contain- } \\
\text { ing local sills of porphyry }\end{array}$ & $240^{\prime} \pm$ \\
\hline 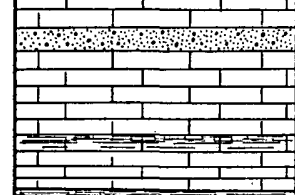 & $\begin{array}{l}\text { Partinǵ quartzite member of } \\
\text { Chaffee formation } \\
\text { Manitou limestone and upper part of } \\
\text { Peerless shale member of Sawatch } \\
\text { quartzite; possibly containing por- } \\
\text { phyry sills }\end{array}$ & $120^{\prime} \pm$ \\
\hline की & $\begin{array}{l}\text { Sawatch quartzite (including lower } \\
\text { part of Peerless shale member) }\end{array}$ & $135^{\prime} \pm$ \\
\hline (1) P & Pre-Cambrian & \\
\hline
\end{tabular}

FIGURE 3.-Generalized columnar section at London Mountain, Alma district, Colorado.

nite porphyry usually serve to distinguish it from the White porphyry, in which phenocrysts are exceedingly rare.

Most of the ore is associated with two contiguous sills-hereafter for convenience called the "porphyry zone"-one of White porphyry and the other of quartz monzonite porphyry, that in places seem to interfinger; they are very close to the base of the Weber (?) formation and contain included layers and lenses of the Weber (?). Other sills higher in the Weber (?) formation have no associated ore.

"Yellow porphyry."-What locally has sometimes been called "yellow porphyry" is altered shale and therefore is mapped as a rock of Weber (?) formation. At a few places surfaces of the white por- 
phyry are stained pale yellow and to a-slight extent resemble the yellow shale.

"Black graphitic" shale.-Along many fissures the fault gouge contains very black, highly carbonaceous shale from the lower part of the Weber (?) formation. The "graphitic" substance was probably derived from original carbonaceous material whose percentage of fixed carbon has been increased by alteration. At many places the shale was included in the porphyry sills when they were intruded.

STRUCTURE

London fault.-The major structural feature in the vicinity of the mine is the London fault. This is a reverse fault, dipping steeply eastward, in wbich the pre-Cambrian rocks to the east have been pushed over the sedimentary series to the west of the fault. However, the attitude of the fault does not remain constant across London Mountain. The angle of dip, which ranges from $60^{\circ}$ to nearly vertical, changes considerably within short distances, as may be seen

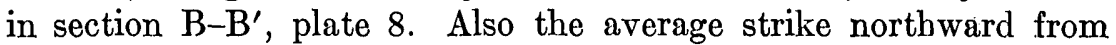
South Mosquito Gulch is N. $30^{\circ}$ W. for about 2,000 feet, then N. $50^{\circ}$ W. to a point just north of the American shaft, and then N. $30^{\circ} \mathrm{W}$. again to the north end of London Mountain. Nearly all the ore that has been discovered lies north of the first bend, though whether this fact has any significance cannot be determined until the region to the south has been more adequately prospected. On Pennsylvania Mountain, where some of the Cambrian quartzite remains east of the fault; the total apparent displacement may be estimated as about 3,000 feet. The London fault has been well exposed in several places in the London mine-namely, in the lower tunnel and in the third level from the Big raise. (See pl. 7.) At these places it is a crushed zone; about 40 feet wide, in which highly brecciated rock alternates with soft clay gouge. The western edge of the fault, however, is reached at several other localities in the mine.

The London fault must have existed at the time of ore deposition, for otherwise the deposits of London Mountain and New York Mountain would not be restricted to the narrow folded and fractured zone adjoining it. Hence the fault may be regarded as essentially of premineral age, but in the Havighorst Tunnel the occurrence along the London fault of ore that is only slightly brecciated, as compared with the intensely crushed rock, proves that there was a small amount of postmineral movement also.

Syncline west of London fault.-The rocks west of the London fault form an asymmetric syncline. On the west limb of this syncline the strata have their rather gentle regional dip, slightly south of east. On the east limb they are sharply turned up against the London fault and dip steeply to the southwest except where the fault crosses the 
crest of London Mountain, where they are slightly overturned. The syncline is doubtless broken by faults trending with the axis of the fold.

Minor faults whose strike is nearly parallel with that of the London fault.-In the footwall country rock of the London fault are innumerable minor auxiliary faults which render the detailed structure exceedingly complex. Many of them have random directions, but most of the larger ones may be classified into two main groups-(1) faults whose strike is nearly parallel with that of the London fault and (2) transverse faults.

The first group, comprising most of the minor faults of the London fault zone, are abundant close to the London fault but in general become less numerous toward the syncline on the west and, so far as is known, do not extend beyond the synclinal axis. Nearly all are sinuous, and their strikes differ, but none diverge more than $30^{\circ}$ from the strike of the London fault. However, they dip at all angles ranging from a few degrees to the soutbwest through vertical to a few degrees to the northeast. Thus they form an intersecting network.

The most abundant of the faults in this group dip southwestward, parallel with or at a slightly smaller angle than the dip of the strata. They dip steeply close to the London fault and moderately farther away. In many places they are at the contact of two types of rocks, as between white porphyry and quartz monzonite porphyry, between a porphyry sill and a sedimentary rock, or between different sedimentary beds. However, they do not necessarily persist at such a horizon either along the strike or along the dip, but may cut from the contact to a course encirely within a rock unit, in this manner reaching successively higher horizons away from the London fault. In their upward extension some of these faults turn into the London fault and therefore do not crop out at the surface. Those that reach the present surface west of the London fault probably also terminated against it at a bigher level, now removed by erosion. Moore reports that some of these faults, like the strata, are overturned and therefore dip steeply eastward in the bighest stopes of the North London workings. Neither the amount nor the direction of displacement on the faults could be observed. Their occurrence only in the zone in which the strata have been turned up against the London fault, their progressive decrease in abundance within this zone away from the fault, and their termination against the London fault prove that they are no younger than the London fault and strongly suggest that they are auxiliary to it and were formed at the same time. Moreover, they were formed before the period of ore deposition, because unbrecciated veins, including most of the ore, as well as veins that are too small or too low grade to be mined, occur in them at many places. However, at a few places, especially in the faults along the contact between two 
types of rock, they contain brecciated ore, showing that there also was postmineral movement on some of them. The so-called West London fault appears to be one of these at the contact between the porphyry zone and the overlying Weber (?) rocks.

Next in abundance are faults that dip northeastward at angles ranging from $35^{\circ}$ to nearly vertical. All whose direction of movement could be ascertained are reverse. The throw of few exceeds 50 feet but in the largest is nearly 200 feet. (See pl. 8, section D-D'.) Their relations to the ore and to the London fault suggest that these faults originated before ore deposition but that most of their displacement was caused by postmineral movement. The premineral age of at least some of them is proved by the occurrence in them of ore (see pl. 8, sections $\mathrm{C}-\mathrm{C}^{\prime}-\mathrm{C}^{\prime \prime}, \mathrm{D}-\mathrm{D}^{\prime}, \mathrm{F}-\mathrm{F}^{\prime}$, and $\mathrm{G}-\mathrm{G}^{\prime}$ ) that either is not brecciated or is in a position that precludes its derivation by drag from southwestward dipping veins, as, for example, at the south end of the North London level, where a vein dipping northeast grades downward into a small replacement ore body in the top part of the Leadville limestone. On the other hand, at many places reverse faults dipping northeastward and containing "drag ore" displace veins dipping southwestward as much as they do the sedimentary strata, thus indicating that essentially all the movement occurred after the veins had formed. Significant relations were found along the large fault which strikes $\mathrm{N}$. $10^{\circ}-15^{\circ} \mathrm{W}$. and dips $75^{\circ}-85^{\circ} \mathrm{NE}$. and which terminates the McDonald vein southward successively on the 400foot, 300 -foot, and 200-foot levels of the Big raise. (See pl. 8, sections $\mathrm{C}-\mathrm{C}^{\prime}-\mathrm{C}^{\prime \prime}$ and $\mathrm{D}-\mathrm{D}^{\prime}$.) At many places this fault contains highly brecciated ore that clearly has been "dragged" by postmineral movement, but at other places unbrecciated ore occurs along its footwall. These relations and the fact that others of the faults contain ore which, although brecciated, is in larger qauntities than can be reasonably accounted for by "drag," favor the interpretation that the faults originated before mineralization but had most of their displacement after mineralization, rather than the alternate hypothesis that some are premineral in age and others, having the same range in dip, are postmineral. At the top of raise 203 of the Extension workings, the only place in the mine where the London fault is exposed at one of the northeastward-dipping reverse faults, the London fault is offset by the other, which shows clear evidence of postmineral movement. (See fig. 4.)

Reverse faults dipping northeast are more abundant in the workings connected with the Big raise and on the South London and North London levels than elsewhere in the mine. (See pl. 8, sections $\mathrm{C}-\mathrm{C}^{\prime}-\mathrm{C}^{\prime \prime}, \mathrm{D}-\mathrm{D}^{\prime}, \mathrm{E}-\mathrm{E}^{\prime}, \mathrm{F}-\mathrm{F}^{\prime}$, and $\mathrm{G}-\mathrm{G}^{\prime}$.) Many of these may be branches, diverging northward and upward, of the large fault that terminates the McDonald vein on the second, third, and fourth levels 
of the Big raise, for in the stopes between these levels there are many small reverse faults, dipping $40^{\circ}-70^{\circ} \mathrm{NE}$., all of which offset the McDonald vein but terminate against the large fault in a manner suggesting that they are auxiliary fractures. Toward the south the large fault doubtless bends and joins the London fault where that fault changes its strike in the vicinity of the American shaft.

Ore has been found principally along the faults that dip at slightly smaller angles than the strata, but to some extent along other faults
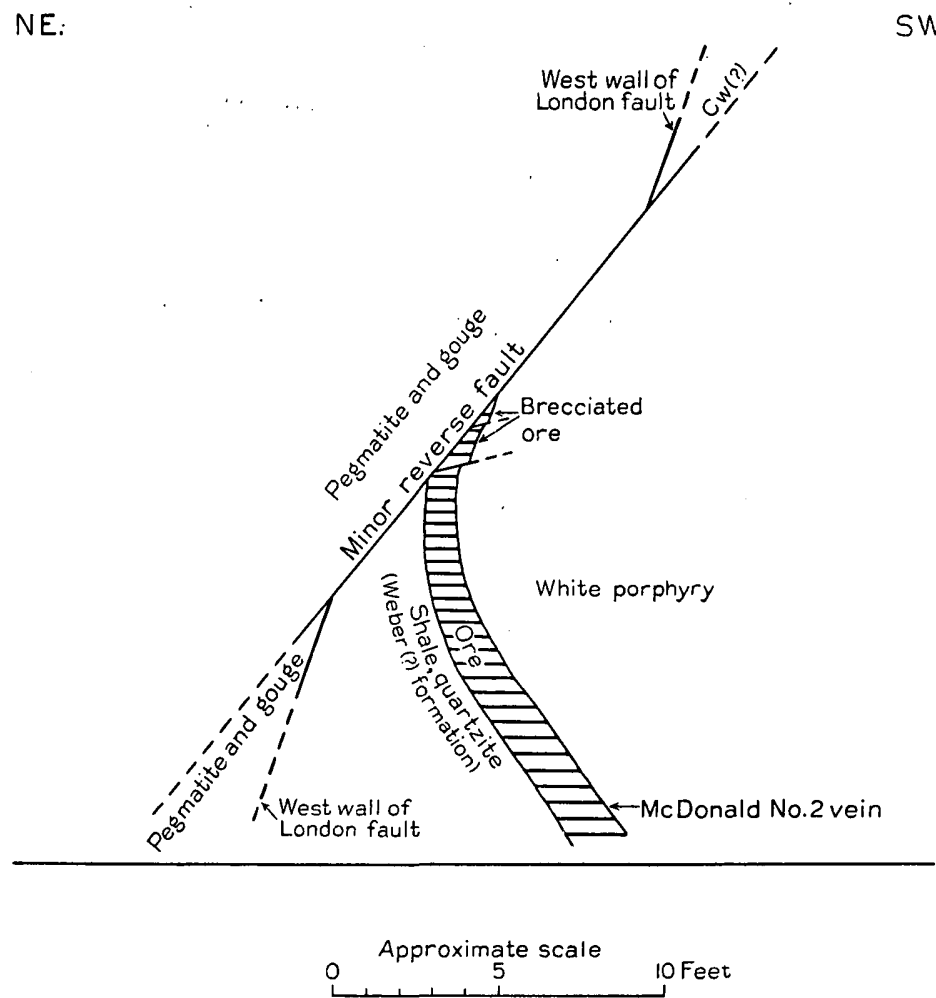

Figure 4.-Sketch showing relation between London fault, McDonald No. 2 vein, and a minor reverse fault at the top of raise 203, London Extension mine, Alma district, Colorado.

of the group whose strikes are nearly parallel with that of the London fault or along faults having random directions. At numerous places where a fault has porphyry on both walls the fissure contains black "graphite" or yellow shale, or even quartzite, of the Weber (?) formation. This material normally ranges from a few inches to 2 feet in thickness, yet may be thicker. At most places the shale was included in the porphyry at the time of intrusion. Because of their planes of easy slipping, the included shale masses determined the position of many faults. Elsewhere the shale was probably "dragged in." In addition, the faults contain brecciated or crushed material derived from the walls. 
Transverse minor faults.-The important transverse faults may be divided into three subgroups. One group strike N. $5^{\circ}-35^{\circ} \mathrm{E}$. and dip from $40^{\circ}$ to nearly vertical, either northwestward or southeastward. Another group strike N. $50^{\circ}-70^{\circ} \mathrm{E}$. and dip steeply to the southeast. The third group strike N. $55^{\circ}-85^{\circ} \mathrm{W}$. and dip at moderate angles, either southwest or northeast. The horizontal shift on them ranges from a few feet to 120 feet. All are normal faults that displace the London fault, the veins, and the northeastward-dipping reverse faults. Although many of the transverse faults are probably postmineral, some are mineralized and therefore must have been initiated before ore deposition.

Summary of folding and faulting.-The main events in the tectonic history of London Mountain, as inferred from the preceding paragraphs and from the section on regional structure, may be summarized as follows: In early Tertiary time stresses acting in a S. $60^{\circ} \pm \mathrm{W}$. direction developed a long, narrow asymmetric anticline with an axial plane dipping steeply to the northeast, and this anticline may be localized along an ancient line of weakness developed by faulting during the pre-Cambrian era. As the stresses increased the rocks broke along a plane that dips steeply to the northeast but does not coincide with the axial plane of the anticline. Faulting then ensued until there was a total apparent displacement of nearly 2,500 feet, the rocks on the east side being moved relatively up. As a result of the grinding action along the surfaces of slipping, considerable quantities of clay gouge formed within the shear zone of the main fault. At the same time stresses caused by drag in the adjoining rocks were relieved by further folding and by development of innumerable minor faults that strike nearly parallel with the main fault but dip at all angles both toward and away from the main fault. These auxiliary faults have small displacements and therefore do not contain much clay gouge. Thus, at the end of the period of intense deformation the shear zone of the main fault was nearly impermeable, but the adjoining rocks were cut by innumerable intersecting minor faults that were relatively permeable. Moreover, the minor faults were most abundant close to the main fault. There then ensued a period of ore deposition. The structural conditions at this time are depicted diagrammatically in figures 5 and 6.

After mineralization renewed movement took place along the main fault and also along many of the auxiliary faults. At this time the planes of the minor faults that dip to the northeast were extended across the main fault, which they displaced. Still later, most of the transverse faults developed.

Slickensides along many of the minor faults show that the latest movement was nearly horizontal. 


\section{OCCURRENCE OF ORE}

General features.-Almost the entire production of the London mine has come from veins that lie entirely within fault fissures having southwest dips, but a little ore has been mined from veins having northeast dips. In a few places veins in or adjoining the Leadville limestone formed replacement deposits in the limestone.

Owing to the complexity of the structure there is some uncertainty as to the identification of the veins throughout the mine; for example, whether veins labeled London, McDonald, etc., originally were formed along continuous fissures or along discontinuous ones at nearly the same stratigraphic positions. According to Moore, at one place in the northern part of the mine the London vein was stoped continuously for a distance of 1,850 feet horizontally, to a height ranging from

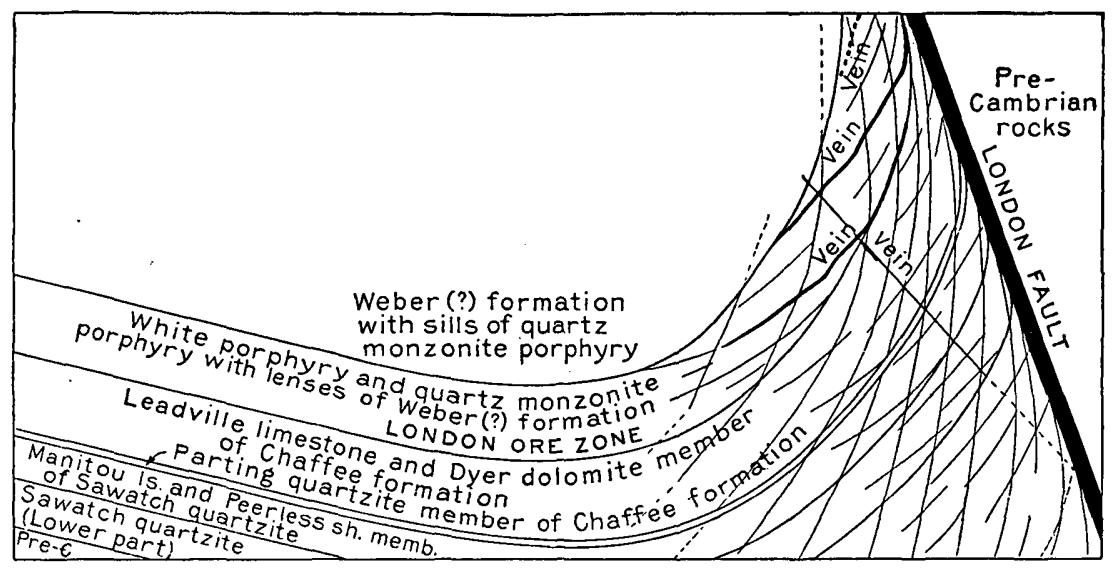

o

SOO FEET

FlaURE 5.-Idealized section at London mine showing faults and ore bodies before period of postmineral faulting.

150 to 650 feet. In the present workings, however, none of the stopes show such continuity, chiefly because they are broken by numerous postmineral faults.

Available reports indicate that; in general, the average tenor of the ore increased progressively from the north end of the mine to the workings north of raise 8 of the Extension level.

London vein.-The London or "Main" vein has yielded most of the production from the North London and South London levels. The principal ore shoot, so far as is indicated by the stope maps, terminates downward along a line pitching gently to the south, which is indicated on Moore's map as the intersection of the London vein and the West London fault. The writers have not been able to examine the bottom of the shoot anywhere except on the 4th level of the Big raise, and there the change seems to come where the vein passes from the "porphyry zone" to the Weber (?) formation; however, at places the vein must 


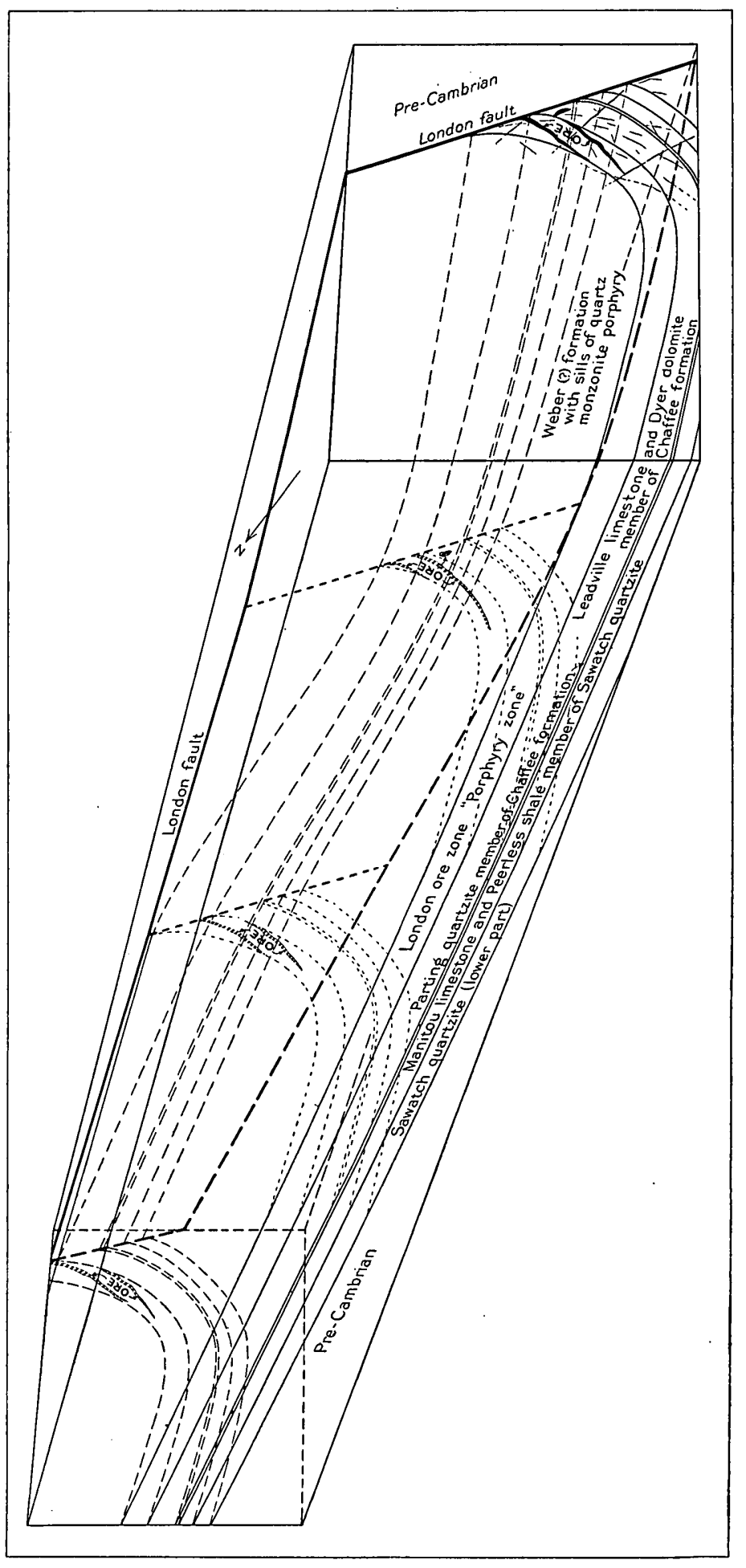

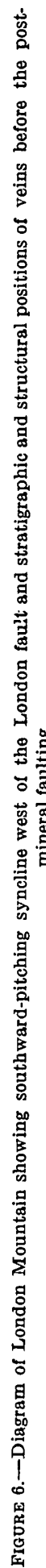


certainly be cut off by postmineral faults. Between the North London and South London levels the vein has an average dip of $65^{\circ}$, which apparently is slightly less than the dip of the strata. Above the North London level the dip steepens, and close to the top of the stopes, where, according to Moore, it coincides with a contact between Leadville limestone and porphyry, it is slightly overturned. None of these stopes are accessible, and they do not reach the surface. Reports indicate that their upward termination may be due to the presence of impermeable crushed shale in the fissure.

What is called the London vein in the Extension workings has nowhere been found to be extensive enough or rich enough to be developed.

McDonald vein.-The McDonald vein, originally called the "contact" vein, is east of the London vein, and the two are roughly parallel. In the higher workings it is at or very close to the upper contact of the Leadville limestone. Below the South London level, however, the dip of the McDonald vein is a little less than the dip of the contact, so the vein occupies approximately the same stratigraphic position that the London vein does above the South London level.

The occurrence of ore in the McDonald vein is essentially the same as in the London vein. The most productive portions have been below the South London level in the vicinity of the Big raise and in the vicinity of raises 6 and 8 of the Extension level (including the American mine). At the latter locality the vein terminates upward against the London fault, although small patches of slightly brecciated ore were found in the London fault up to the Havighorst level; the downward termination has not yet been reached. Numerous transverse fissures in the area, some of them slightly mineralized, may have permitted access of ore-forming solutions to the veins. Immediately south of the Big raise the ore dies out downward, where the vein flattens markedly as it extends farther from the London fault toward the synclinal axis to the west. The upward termination of the ore at this locality is marked by stopes above the South London level that are now inaccessible. According to Moore, the McDonald vein yielded rich ore locally in the older workings above the South London level but was unproductive in the central portion, where the London vein was most productive. Since 1933 small amounts of ore whose zinc content is slightly higher than the average, have been produced from the nearly vertical London and McDonald veins in the reopened Middle tunnel, above the Blanchard level, by the West London Mines Co., lessees. The McDonald vein at this locality is in a fault that displaces the beds in the south wall horizontally for about 30 feet eastward.

The southward termination of ore in the McDonald vein has not yet been located, but the southernmost ore body so far discovered was 
opened in 1933. It extends 300 feet southward from a point 400 feet south of raise 8 and 200 feet above the Extension level.

Other ore bodies.- On the North London level and elsewhere in the mine veins that are not persistent have locally yielded rich ore. Most of them dip to the southwest, but in several places (see pl. 8, sections $\mathrm{C}-\mathrm{C}^{\prime}-\mathrm{C}^{\prime \prime}, \mathrm{D}-\mathrm{D}^{\prime}, \mathrm{F}-\mathrm{F}^{\prime}$, and $\mathrm{G}-\mathrm{G}^{\prime}$ ) the veins dip eastward. At other places the workings have cut mineralized fissures which, although essentially like the productive fissures, are not profitable where opened.

Significant quantities of ore have been mined from the Leadville limestone at three localities-(1) near the south end of the North London workings, (2) in the "daylight stopes" near the south end of the South London workings, and (3) in and adjacent to the American mine. In the North London the ore was along a fissure dipping $55^{\circ}-60^{\circ} \mathrm{NE}$. and replaced the limestone to a maximum distance of about 20 feet from the fissure. The ore body has been mined for 600 feet along the strike through a maximum vertical range of 200 feet, though the bulk of the ore was just below the top of the Leadville limestone. The relations of this ore body to the overlying McDonald vein are shown on plate 8 , section $F-F^{\prime}$. South of the section the London fault cuts off both the limestone ore body and the McDonald vein but contains brecciated ore that has been mined for a horizontal distance of 50 to 60 feet.

The ore shoot in limestone in and adjoining the American mine also is a replacement body along a fissure dipping to the east. The dip is $50^{\circ}$ at the London fault but flattens to $30^{\circ}$ above and westward from the London fault. The bulk of the ore was mined immediately below the top of the Leadville limestone. At one locality the ore has broken through the rocks overlying the Lieadville limestone to the McDonald No. 1 vein. As in the North London workings, the upper contact of the Leadville limestone steepens but is not displaced where joined by the eastward-dipping fissure. However, locally the fissure contains a strong breccia of various rocks including preCambian. This conflicting evidence as to the amount of movement on the eastward-dipping fissure could be reconciled by assuming nearly horizontal movement of a block bounded by the London fault, the eastward-dipping fissure, and the limestone-shale contact.

The ore in the limestone at both the above-mentioned localities is like that in the veins of the "porphyry zone" except that it is richer in the sulphide minerals and poorer in gold. Nothing is known regarding the ore or its occurrence in the "daylight stopes."

Relations of veins to enclosing rocks.-More than 90 percent of the output has come from two veins, the London vein and the McDonald vein, which may be along discontinuous fissures at nearly the same stratigraphic positions. These veins dip a little more gently than the enclosing rocks and therefore pass downward to stratigraphically 
higher horizons. In general, the large ore shoots on each vein are restricted to approximately the same horizons, within or along the contacts of the contiguous sills of quartz monzonite porphyry and White porphyry that are very close to the base of the Weber (?) formation. Where the veins pass from these porphyries into the underlying rocks they locally contain ore to the upper part of the Leadville limestone. But where they pass from these porphyries into the overlying rocks - the Weber (?) formation and other porphyry sills higher in the Weber (?)-they are barren. These conditions would indicate that the distribution of the ore depends more on stratigraphic position than on a particular fissure, although at the favorable horizons the ore is confined to continuous and permeable fissures. The conditions above are illustrated in figures 5 and 6 .

In spite of the relatively small quantity of ore so far produced in the Leadville limestone, the upper part of this formation must be considered as of some promise in view of the ore occurrences described in the preceding section.

\section{GENERAL APPEARANCE OF ORE}

The characteristic mineralogic and textural features of the hypogene ore remain essentially the same throughout the London vein system. The mineralogy is relatively simple, and variations as to detail are the result of variations in the proportions of the same minerals rather than the presence of different minerals. The predominant constituent is a slightly glassy variety of milky quartz, occurring in grains that range in size from microcrystalline to coarse but nowhere exceed 3.0 centimeters in length. Aggregates of the large grains commonly exhibit a poorly developed comb structure. Pyrite, dark sphalerite, galena, and chalcopyrite occur in varying proportions, but their usual order of abundance is as named. Normally the sulphide minerals are common but subordinate constituents, yet all gradations exist from ore in which they are almost as abundant as quartz to nearly pure quartz. They form minute veinlets, small clusters, and large irregular-shaped masses that are usually interstitial to the large quartz grains but intimately associated with the small ones. Some of the sulphide masses are so oriented as to give the ore a rudely banded aspect or to accentuate the comb structure, but this is somewhat obscured by other masses that are unoriented. At some places all the sulphide minerals are intimately intergrown, but elsewhere pyrite occurs apart from the other three. Insignificant amounts of calcite (table 3) normally occur in widely spaced, very narrow veinlets which transect quartz and the sulphide minerals. Locally but rarely calcite is an abundant constituent.

Free gold, which is readily seen in the pockets of exceptionally rich ore, occurs as flakes having ragged outlines and as tiny veinlets. 
It is most common in or near small masses of intergrown sphalerite, galena, and chalcopyrite, though it may be distributed within any of the sulphide minerals, at the contact of a sulphide mineral with quartz, or within quartz. However, in the bulk of the ore gold is not visible to the naked eye. The gold content seems to be associated with sphalerite, galena, and chalcopyrite, for where the vein consists solely of quartz, or of quartz and pyrite, it is almost invariably not workable.

Traces of other hypogene minerals doubtless exist in places, but none was seen in any specimens available to the writers.

In addition to the above-named minerals, the ore contains included fragments, thin layers, and filaments of either shale or porphyry, or of both. The filaments and thin layers are oriented approximately parallel with the walls of the vein and therefore tend to accentuate the banded aspect. Moreover, such layers constitute planes along which the ore easily breaks with very smooth surfaces. The quantity of included rock varies greatly from place to place but in general decreases as the tenor of the ore increases.

Near the surface the sulphides were largely oxidized, but there was no opportunity to study this ore underground. So far as could be seen from the dumps there was nothing unusual in the character of the oxidation and no very notable enrichment during the process.

\section{DETAILED MINERALOGY OF HYPOGENE ORE}

Minerals in altered wall rock.-In and immediately adjoining the veins both porphyries are exceedingly altered. They essentially retain their original texture but consist solely of quartz, sericite, and insignificant amounts of apatite or other accessory minerals. The quartz and sericite in part are preexisting magmatic or end-phase minerals and in part are products formed by the replacement of the other minerals during the period of local alteration associated with ore deposition. A short distance from the veins carbonate is associated with the quartz and sericite. Still farther away the rock grades into normal porphyry which shows only the end-phase alteration that is common to the porphyry as a whole.

The shales of the Weber (?) formation, in addition to being considerably mashed from the faulting, are recrystallized. The yellow shale in the fissures consists of a sericite mat which encloses small rounded masses of dark carbonaceous material and angular quartz grains (pl. 9); also it is penetrated by sericite veinlets. The black "graphitic" shale consists of opaque carbonaceous material which encloses irregular-shaped masses of matted sericite, or sericite and carbonate, and some pyrite.

The quartzites of the Weber (?) formation have been slightly sericitized, but they are relatively unaltered. Likewise, the Leadville 
limestone shows almost no alteration where it was seen adjoining veins.

The wall-rock alteration preceded the deposition of the veins, for early vein quartz transects the altered rocks.

Gangue minerals.-Quartz is the predominant gangue mineral, but it is accompanied by subordinate amounts of sericite, a little calcite (the only carbonate present in sufficient quantities to be determined), and insignificant amounts of carbonaceous material. Sericite, carbonaceous material, and a little of the quartz are residual from included rock fragments. Calcite and most of the quartz were introduced in solution.

Two distinct varieties of quartz can be recognized in all thin sections (pl. 10, $A, B$ ). One variety, which constitutes most of the vein, is coarse- to medium-grained and has typical vein-quartz structure. The other variety is fine-grained to microcrystalline; it may be alone or intergrown with sericite. The quartz-sericite intergrowths are recrystallized fragments of porphyry in which sericite is somewhat less abundant and quartz grains are slightly larger than originally. Brecciation, solution, and reprecipitation of the coarser quartz account for at least part of the fine-grained and microcrystalline quartz that is not intergrown with sericite, as shown by gradations from incipient veinlets of microcrystalline quartz transecting several differently oriented grains of coarser quartz (see pl. 10, $A$ ), to small shear zones composed of microcrystalline quartz containing brecciated remnants of coarser quartz (see pl. 11, $A, B$ ). The sulphide minerals in general are localized in areas of fine-grained and.microcrystalline quartz, or sericite and quartz; on the other hand, veinlets of microcrystalline quartz at places transect all sulphide minerals. Hence, after precipitation of the coarse- to medium-grained quartz, the fine-grained to microcrystalline quartz formed during a long period that began before and lasted until after precipitation of the sulphide minerals; however, the ore solutions probably introduced appreciable quantities of silica only at the time the coarse- to medium-grained quartz was being precipitated.

The earliest calcite formed contemporaneously with the latest quartz, for in some veinlets the two are intimately intergrown. Most of the calcite, however, occurs in veinlets that transect all other hypogene minerals.

That early vein quartz formed principally as a fissure filling is attested (1) megascopically by the fact that the veins are within fault fissures, do not merge into the adjoining wall rock, and almost nowhere are frozen to the walls, and (2) microscopically by the fact that small veinlets, whose entire width is seen in a single thin section, generally have rather sharply defined boundaries (see pl. 12, A), uniform width over short distances, and walls that match; moreover, 


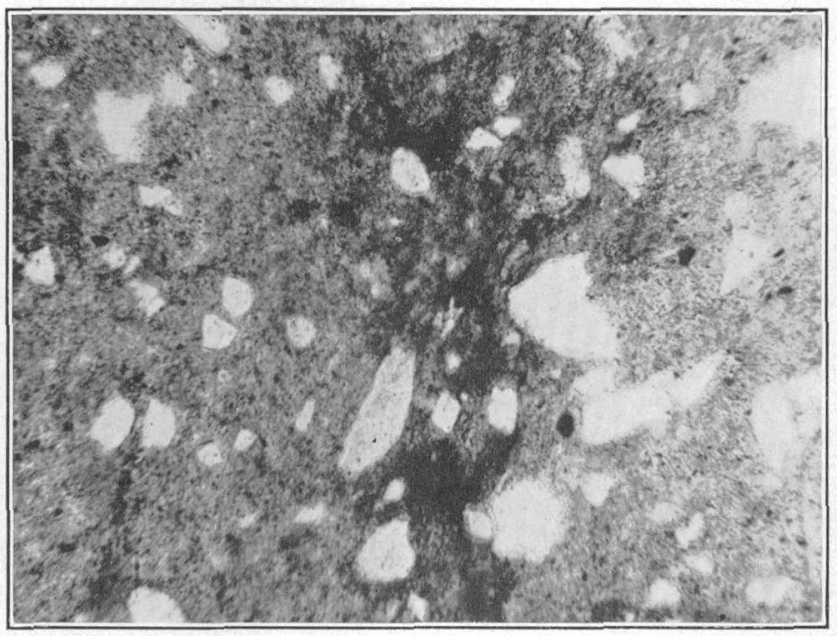

PHOTOMICROGRAPH OF YELLOW WEBER (?) SHALE ("YELLOW PORPHYRY").

Consists of matted sericite enclosing angular quartz grains as well as specks and masses of carhonaceous material. Thin section. Uncrossed nicols. X 100. 


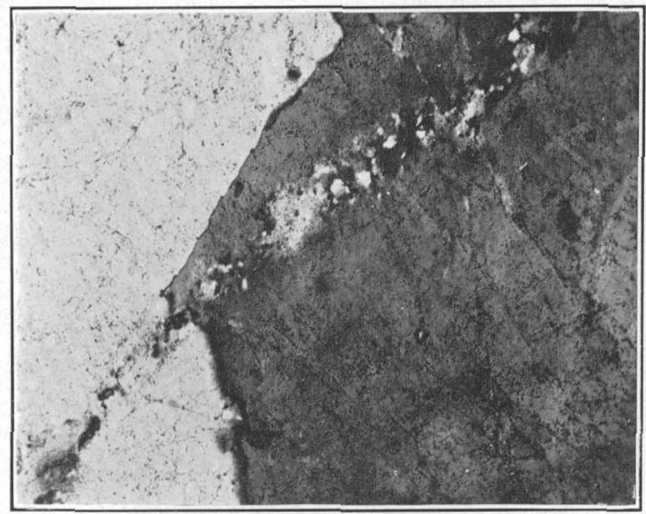

A. INCIPIENT VEINLET OF MICROCRYSTALLINE QUARTZ TRANSECTING TWO DIFFER. ENTLY ORIENTED GRAINS OF COARSE VEIN QUARTZ.

Thin section. Crossed nicols. $\times 100$.

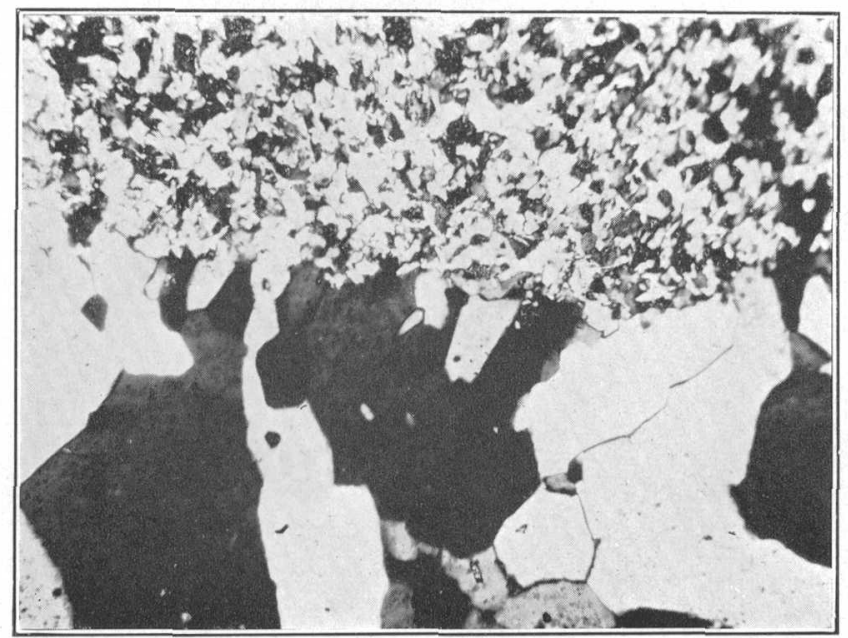

B. CONTACT OF QUARTZ VEINLET THAT FORMED ESSENTIALLY AS A FISSURE FILLING IN WHITE PORPHYRY COMPOSED OF QUARTZ AND SERICITE.

Thin section. Crossed nicols. $\times 67$.

PHOTOMICROGRAPHS OF ORE AND GANGUE FROM LONDON VEIN. 


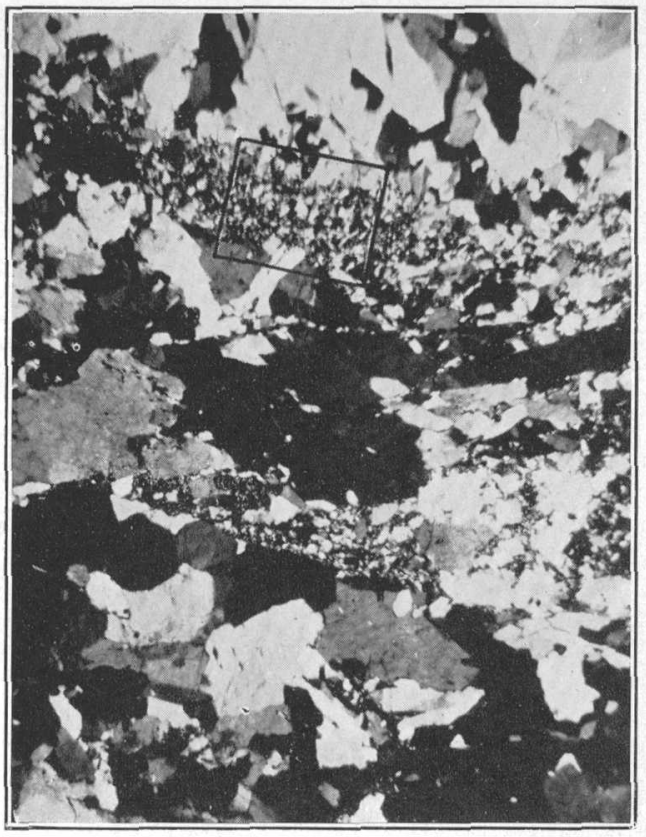

A. MEDIUM-GRAINED AND COARSE VEIN QUARTZ TRANSECTED BY SMALL SHEAR ZONE COMPOSED OF MICROCRYSTALLINE QUARTZ AND FRAGMENTS OF VEIN QUARTZ.

Thin section. Crossed nicols. $\times 18$.

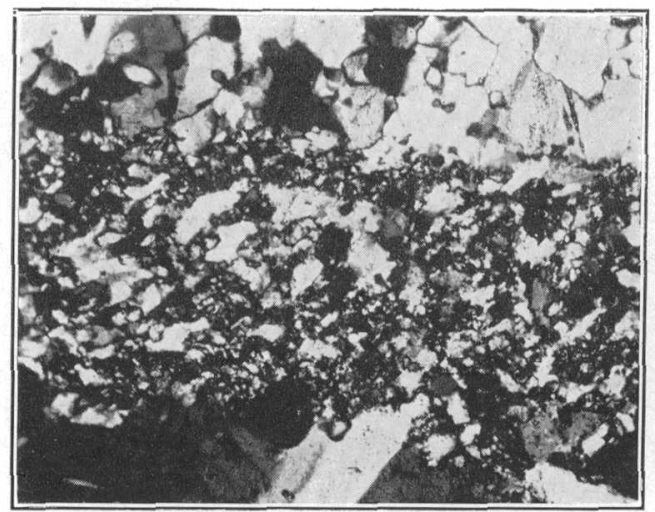

B. UPPER CENTRAL PART OF $A$.

Thin section. Crossed nicols. $\times 100$.

PHOTOMICROGRAPHS OF ORE AND GANGUE FROM LONDON VEIN. 


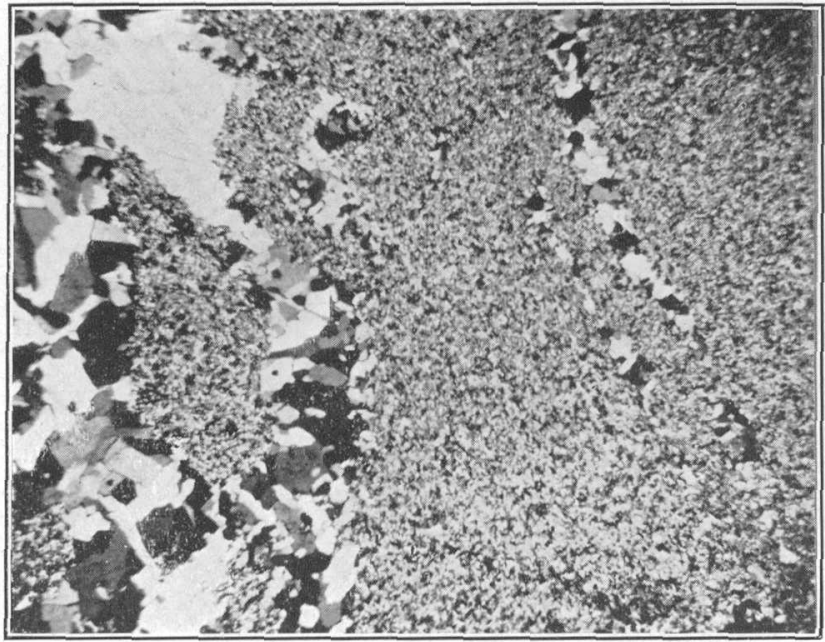

A. FRAGMENT OF WHITE PORPHYRY ENCLOSED BETWEEN TWO BRANCHES OF A QUARTZ VEINLET.

Porphyry composed of quartz and sericite. Thin section. Crossed nicols. $\times 19$.

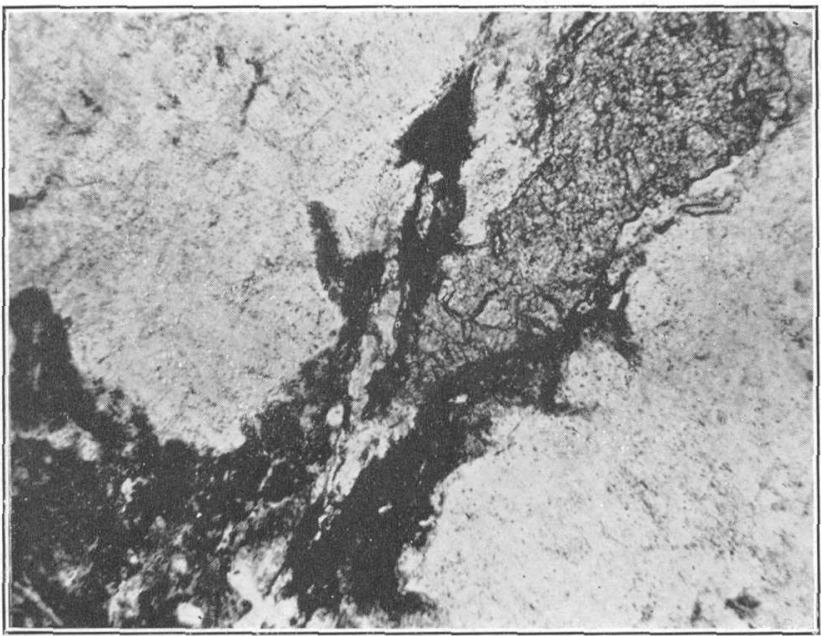

B. SHALE FRAGMENT CORRODED BY VEIN QUARTZ; BOTH SHALE AND VEIN QUARTZ CORRODED BY CALCITE.

Vein quartz, white; calcite, gray, high relief; shale fragment, composed of sericite and carbonaceous material, black. Thin section. Uncrossed nicols. $\times 100$.

PHOTOMICROGRAPHS OF ORE AND GANGUE FROM LONDON VEIN. 


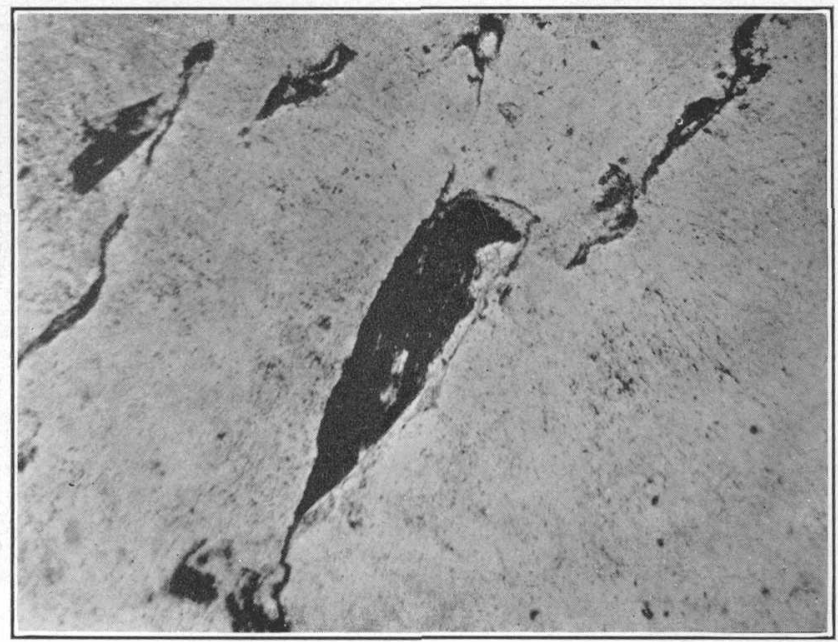

A. SHALE FRAGMENTS IN VEIN QUARTZ. Streaks of carbonaceous material extend from shale into vein quartz. Thin section. Uncrossed nicole.

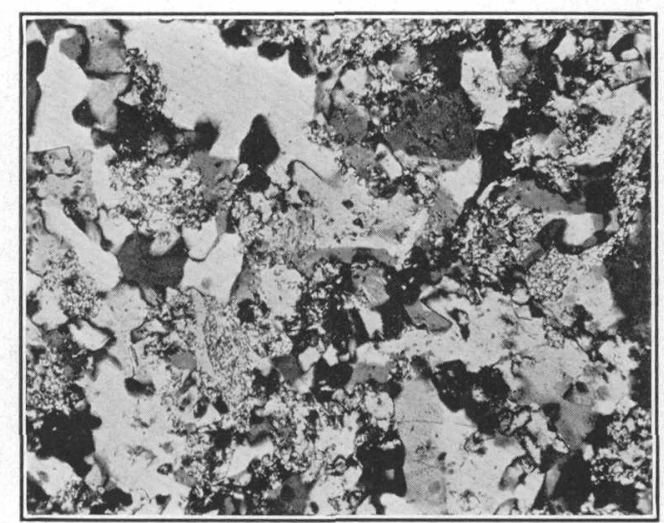

B. VEIN QUARTZ CONTAINING ABUNDANT TINY FRAGMENTS OF PARTLY ASSIMILATED PORPHYRY.

Most of the vein quartz is recrystallized rock quartz. Sericite has been subtracted from the recrystallized portions. Thin section. Crossed nicols. $\times 97$. 


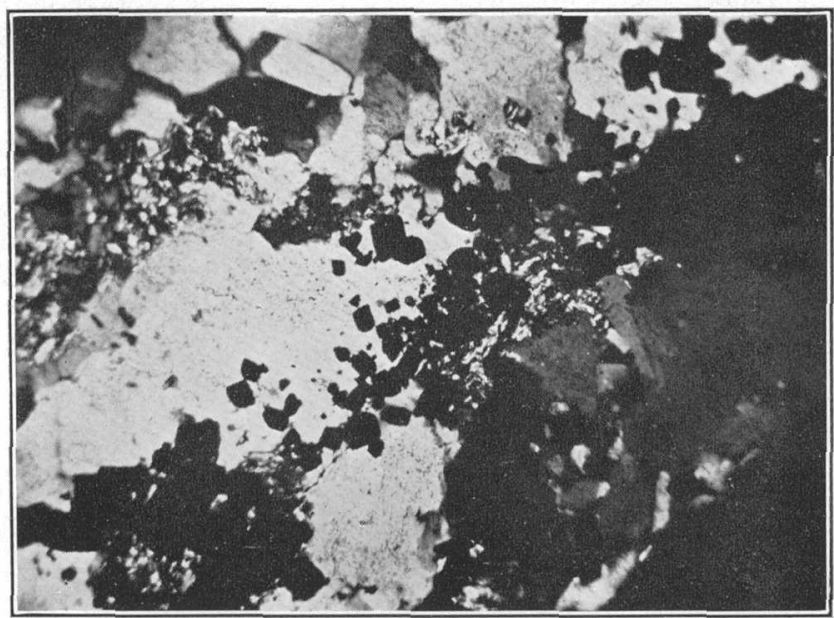

A. PYRITE LOCALIZED IN AREAS OF FINE-GRAINED AND MICROCRYSTALLINE QUARTZ (ALONE OR INTERGROWN WITH SERICITE) WHICH ARE INTERSTITIAL TO COARSER VEIN QUARTZ.

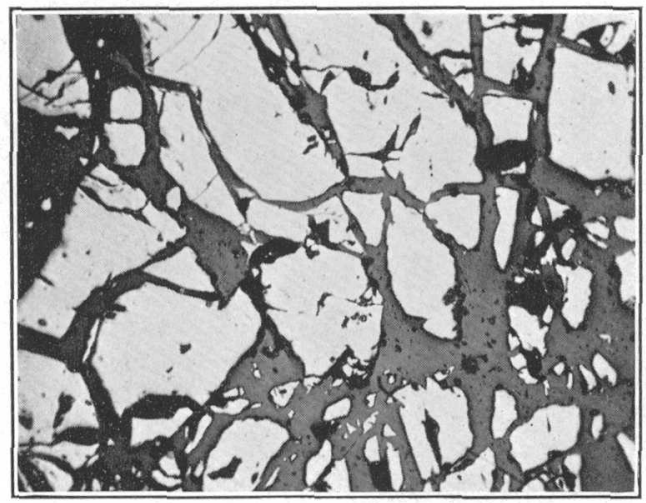

B. SPHALERITE HEALING FRACTURES IN PYRITE.

The sphalerite formed principally as a fissure filling but replaced pyrite to some extent. Polished section. $\mathrm{C}$ (blue-violet) and $\mathbf{H}$ (blue) filters. $\times 100$.

PHOTOMICROGRAPHS OF ORE AND GANGUE FROM LONDON VEIN. 


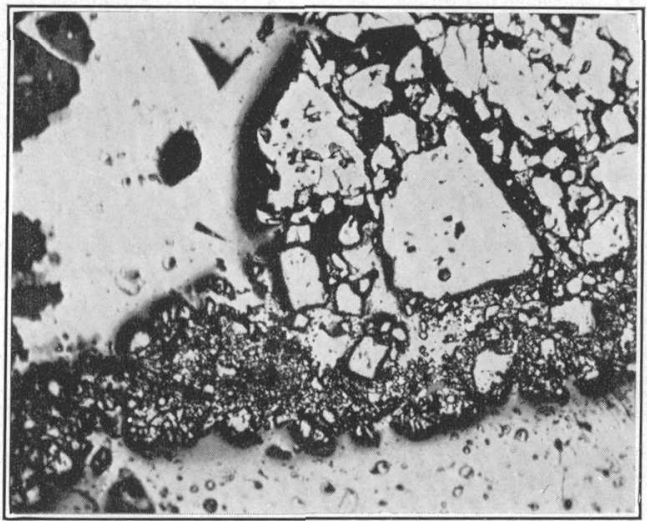

A. SHEAR ZONE CONTAINING HIGHLY GRANULATED PYRITE ADJOINING AND EXTEND. ING FROM PYRITE THAT IS SLIGHTLY BRECCIATED.

Pyrite, white, high relief; galena, white; chalcopyrite, whitish gray; sphalerite, dark gray. Polished section. $\mathrm{C}$ (blue -violet) and $\mathrm{H}$ (blue) filters. $\times 100$.

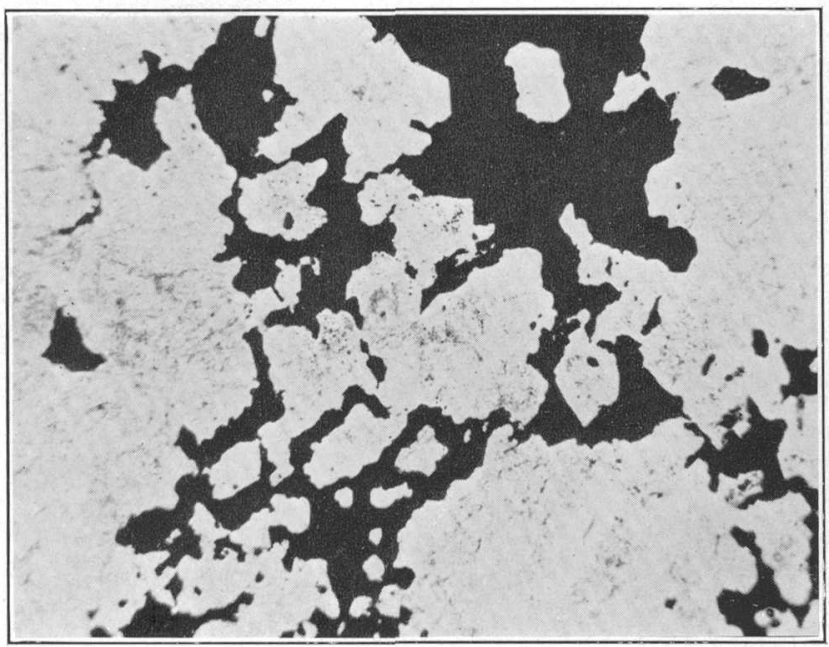

B. GALENA INTERSTITIAL TO AND ENCLOSING GRAINS OF VEIN QUARTZ.

Thin section. Uncrossed nicols. $\times 85$.

PHOTOMICROGRAPHS OF ORE AND GANGUE FROM LONDON VEIN. 

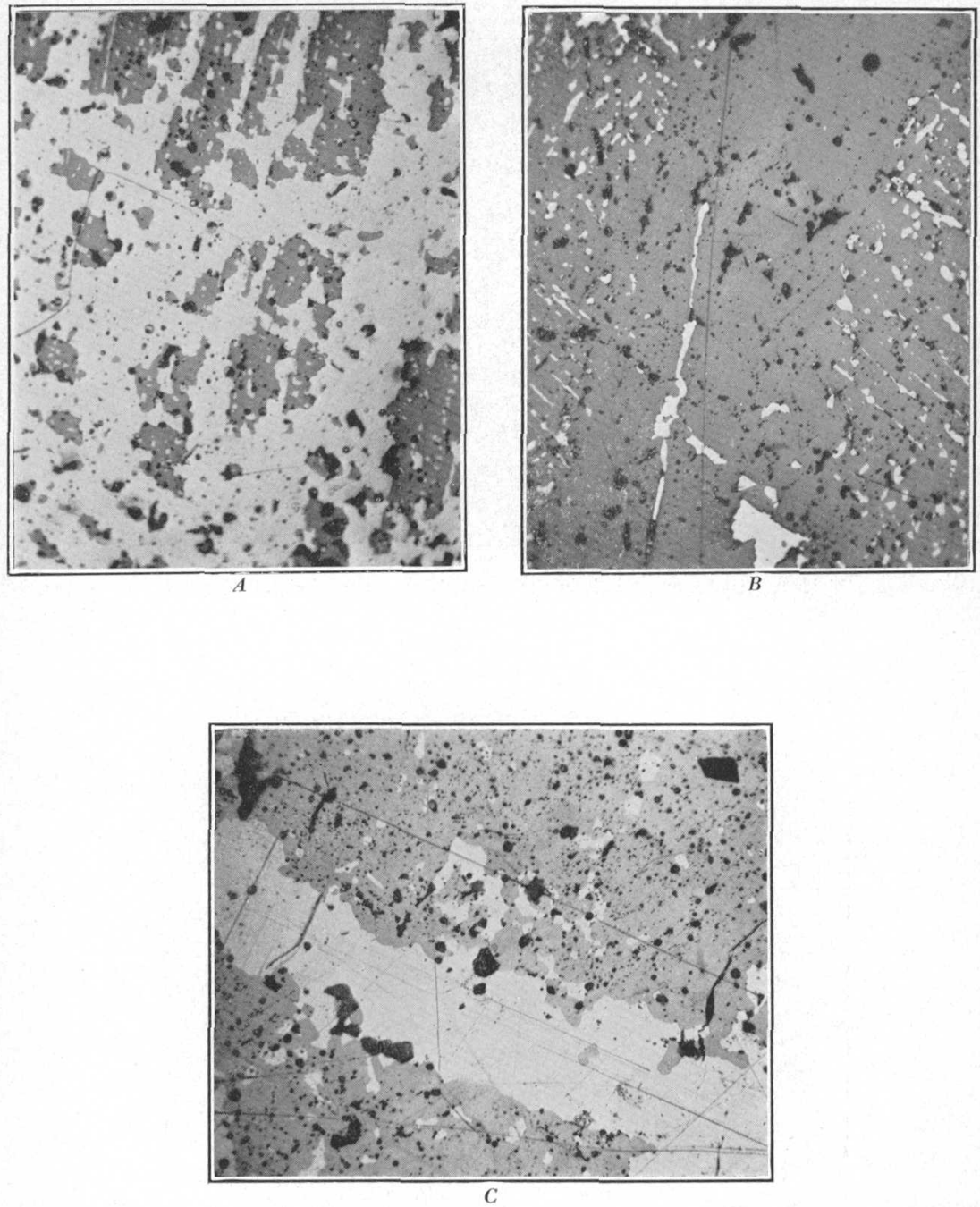

$A$. Sphalerite extensively replaced by chalcopyrite. Orientation of chalcopyrite blebs shows that several sphalerite areas have same crystallographic orientation and are fragments of a single original grain. $B$. Phantom veinlet of sphalerite that is free of chalcopyrite blebs, in sphalerite that contains blebs of the type formed by replacement. This relation indicates that sphalerite and chalcopyrite slightly overlap in age. Galena grains and veinlet are in the sphalerite that is free of chalcopyrite. $C$. Veinletlike tongue of galena in chalcopyrite. Galena, white; chalcopyrite, light gray.

\section{PHOTOMICROGRAPHS OF ORE AND GANGUE FROM LONDON VEIN.}

Polished sections. C (blue-violet) and $\mathrm{H}$ (blue) filters. $\times 100$. 

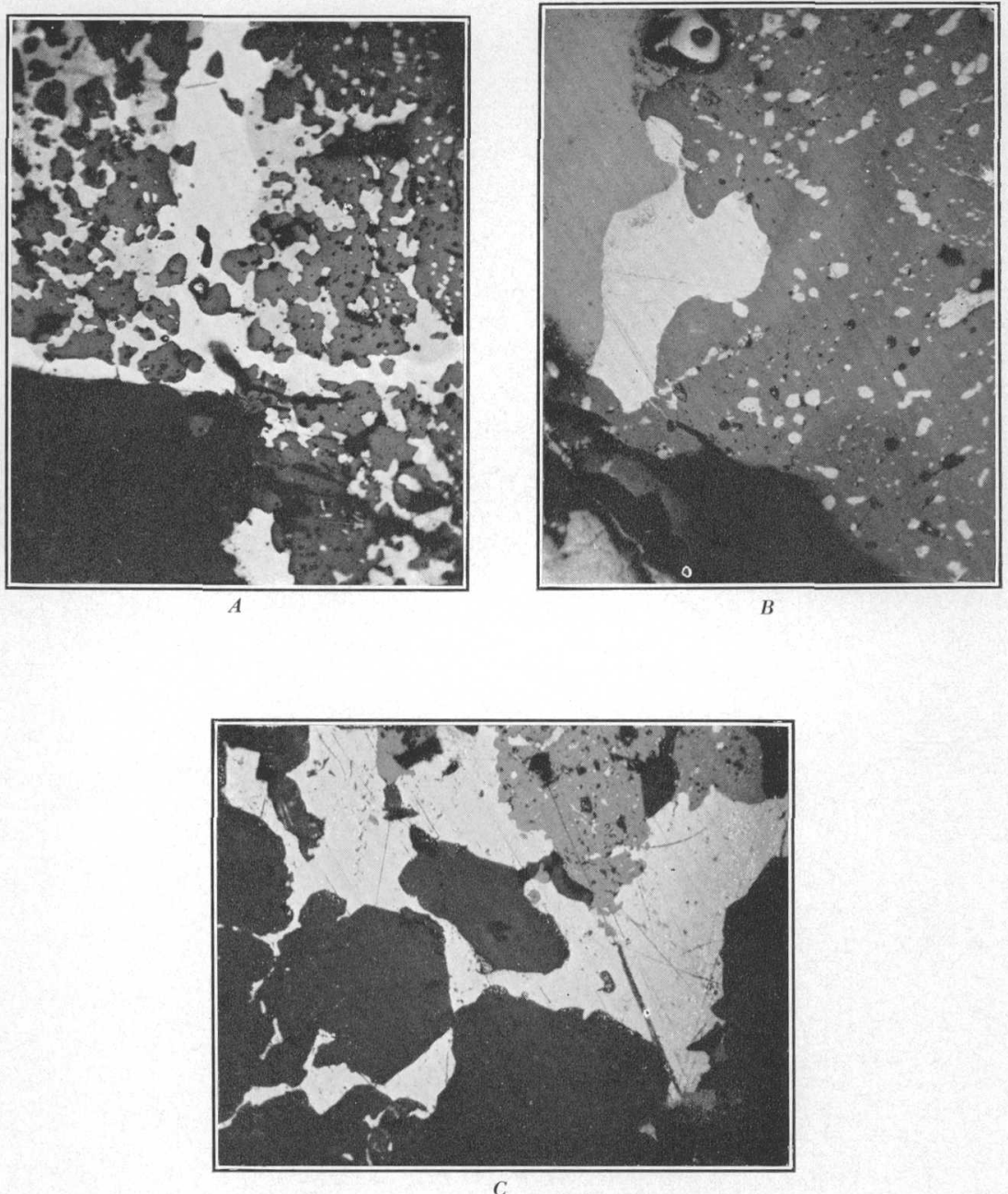

A. Galena veinlets transecting chalcopyrite that has partly replaced sphalerite. Galena, white; chalcopyrite, whitish-gray; sphalerite, dark gray; quartz (and pits), black. C (blue-violet) and $H$ (blue) filters. B. Gold at contact of galena and sphalerite. The sphalerite contains chalcopyrite blebs that probably formed by exsolution. Gold, white; chalcopyrite, whitish-gray blebs in sphalerite; galena, light gray; sphalerite, medium gray; pyrite, light gray, high relief. A (orange-red) filter. C. Gold at contact of sphalerite and quartz. Gold veinlets extend into quartz interstitial to the coarse vein quartz. Gold, white; chalcopyrite, whitishgray blebs in sphalerite; sphalerite, medium gray; quartz, very dark gray. C (blue-violet) and $\mathrm{H}$ (blue) filters.

PHOTOMICROGRAPHS OF ORE AND GANGUE FROM LONDON VEIN.

Polished sections. $\times 100$ 。 
in one thin section of quartz monzonite porphyry in which an original quartz phenocryst touches a quartz veinlet, the groundmass border of the phenocryst is displaced by the veinlet. Nevertheless, a subordinate part of the early vein quartz was derived by interaction between the ore solutions and rock fragments that, as is illustrated on a small scale by plate $12, A$, were enclosed in vein quartz formed by fissure filling. Some of the included rock fragments were not appreciably affected by the ore solutions, but others underwent a replacementlike transformation during which the rock quartz was recrystallized to vein quartz, while sericite and carbonaceous material were removed. Evidence of such interaction is fairly widespread. Some of the included fragments of both shale and porphyry have their boundaries corroded by the vein quartz, as shown in plate $12, B$. Moreover, many of the corroded porphyry fragments are surrounded by vein quartz that is impregnated with sericite whose abundance decreases away from the fragment, and a few of the shale fragments contain streaks of carbonaceous material that extend without interruption into the adjoining vein quartz (see pl. 13, $A$ ), although the carbonaceous material in most of the shale fragments ends abruptly at their margins. Further evidence of interaction is shown by some of the quartz veinlets which have transitional boundaries with porphyry wall rocks or contain irregular-shaped areas of quartz and sericite (see pl. 13, B) that may or may not extend across the entire veinlet or that open out into chambered areas that could not be fissure fillings. Even the much more numerous quartz veinlets that formed principally as fissure fillings with essentially sharp boundaries really merge into the enclosing porphyry wall rock through a transition zone that is about one two-hundredth of the thickness of the veinlet.

When the coarse- and medium-grained quartz ceased to be precipitated, the veins had become relatively impermeable. They were reopened, however, as a result of brecciation, presumably caused by a tendency for continued movement along the faults. Innumerable cracks and minor shear zones developed in the quartz and in the smaller of the porphyry fragments. Fine-grained and microcrystalline quartz, which, at least for the most part, was derived from the earlier vein quartz or from unassimilated porphyry, first formed in these new openings, but pyrite, the earliest sulphide mineral, was precipitated before the veins again became sealed. Then followed other stages of brecciation, each followed in turn by renewed deposition.

Sulphide minerals.-Pyrite, the oldest sulphide mineral, is widespread as grains that tend to be subhedral cubes. At some places the grains are closely spaced or interlocking, so as to form bands and irregular-shaped aggregates, which are oriented parallel with the vein walls. Elsewhere the grains are isolated. Examination of thin 
sections shows that in general pyrite is associated with the microcrystalline quartz (see pl. 14, $A$ ), so it must have been localized in openings that developed after deposition of the early vein quartz. This relation is unmistakably seen at one place where a line of disconnected pyrite grains, associated with a veinlet of early quartz in porphyry, starts in a small quartz-sericite area within the veinlet, passes to the contact of the veinlet with the wall rock, enters the wall rock, returns to the contact, and eventually reaches a shear zone within the veinlet. Almost everywhere the pyrite itself is transected in all directions by veinlets of gangue minerals or of sulphide minerals, or both, that obviously formed along fractures resulting from brecciation. (See pl. 14,B.) The extent of the fracturing differs, even in a single specimen, but on the whole is moderate; nevertheless, local zones of highly granulated pyrite extend across some polished sections. (See pl. 15, A.) Most of the fractures have been healed by gangue, yet a considerable number contain one or more of the other sulphide minerals, alone or intergrown with gangue, and native gold is present in a few. The contacts indicate that at most places all the later sulphide minerals replaced pyrite to a small extent, but all gradations may be observed from pyrite that is extensively corroded and embayed to pyrite that is transected by veinlets that have matched walls and show no sign of replacement. These relations prove that brecciation in the veins occurred before deposition of pyrite and again after deposition of pyrite but before deposition of the other sulphide minerals.

Sphalerite, galena, and chalcopyrite are distributed in a manner suggesting that they formed almost contemporaneously. They occur singly or, more commonly, intergrown in masses that differ greatly in size and shape. The smallest occurrences are minute stringers interstitial to and partly or wholly enclosing quartz (see pl. 15, $B$ ) and commonly extending outward from the margins of larger grains. The largest masses, which may extend continuously across a polished section, have exceedingly uneven boundaries but usually are elongated approximately parallel with the pyritic bands. The intermediate-sized grains and aggregates have no characteristic shape or orientation, but almost all have very uneven boundaries.

The sphalerite, galena, and chalcopyrite may or may not be associated with pyrite. These relations and the abundance of quartz veinlets in brecciated pyrite suggest that during or after the period of postpyrite brecciation many of the openings were sealed by quartz. The remaining openings, whose location was entirely unrelated to the position of pyrite, carried the solutions from which sphalerite, chalcopyrite, and galena were precipitated. The gradations in occurrence and size from small interstitial stringers through masses of moderate size containing included quartz grains to larger masses 
free of inclusions suggest that the sulphide masses grew by replacing shattered quartz.

Although the postpyrite sulphide minerals are closely associated in occurrence and age, their boundary relations (see pls. 16, $A, B, C$, $17, A$ ) show that they formed in sequence-sphalerite, chalcopyrite, galena. The early age of sphalerite with respect to the other two is shown at many places. It is transected by veinlets of chalcopyrite and of galena. Also, commonly it is corroded and dissected by chalcopyrite and galena, and in places closely spaced grains of highly dissected sphalerite with a common crystallographic orientation are enclosed in chalcopyrite or galena. Positive proof as to the relative ages of chalcopyrite and galena is seldom found, in spite of the fact that these two minerals are intimately associated, even in small veinlets and blebs. Nevertheless, the earlier age of chalcopyrite is established with reasonable certainty by the observations that follow. At one place a chalcopyrite veinlet in sphalerite is transected by a galena veinlet, and at many places tongues of galena extend into chalcopyrite and seem to corrode it. Also, small irregular-shaped masses of galena are common at chalcopyrite-sphalerite contacts, suggesting that these contacts served to localize some of the galena. Furthermore, blebs and masses of chalcopyrite enclosed in galena are commonly located close to grain boundaries and appear to be "islands" separated from the "mainland," some of them only by a very narrow veinlet, whereas blebs and masses of galena in chalcopyrite show no such relations.

In contrast to the sphalerite in replacement deposits in limestones (p. 60), the sphalerite in the veins has a high iron content and is impregnated with an abundance of chalcopyrite blebs. Some blebs, which are tiny and have random distribution, were probably formed by ex-solution, but others undoubtedly were formed by replacement. Those formed by replacement are distributed along crystallographic directions, but they may be (1) without definite shape, (2) slightly elongated in the direction of their alinement, or (3) so elongated that many adjoining blebs coalesce. Gradations may be observed between all three varieties and also between the third variety and true veinlets whose replacement origin is certain. Rarely, grains or phantom veinlets of sphalerite containing no chalcopyrite blebs are seen (pl. 16, B).

Gold.-Native gold occurs in small grains with smoothly curved margins or in short, hackly stringers some of which form networks. Although not localized with any particular mineral, it is almost always found associated with or in the vicinity of small masses of one of the three late sulphide minerals. Most commonly it is located along grain boundaries-between two sulphide minerals (see pl. 17, $B$ ), between a sulphide mineral and quartz (see pl. 17, $C$ ), or between two 
quartz grains (see pl. 17,C). Less commonly it is intergrown with microcrystalline quartz in minute veinlets that transect other quartz. Rarely, it is wholly enclosed in one of the sulphide minerals or has healed cracks in pyrite. From these relations it may be concluded that native gold belongs to the same general period of deposition as sphalerite, chalcopyrite, and galena but is younger than all of them. The gold stringers probably formed by filling fractures, but the more or less equidimensional grains could have attained their shape only by replacing the adjoining minerals, which commonly are sphalerite, chalcopyrite, or galena.

Summary of paragenesis.-The relations above set forth, mostly determined through a study of thin sections and polished sections, indicate that the following sequence of events, shown in figure 7 , occurred during the period of ore deposition.

1. Wall-rock alteration that was exceedingly intense in the fissures and progressively less intense to a distance of several hundred feet from the fissures. This alteration was accomplished through replacement by hydrothermal solutions that were depositing quartz and sericite in and immediately adjoining the fissures and quartz, sericite, and carbonate farther away.

2. Deposition of large quantities of coarse- to medium-grained vein quartz, by fissure filling accompanied by a subordinate amount of recrystallization of rock quartz and subtraction of a little sericite and carbonaceous material.

3. Moderate brecciation of the vein material.

4. Solution and reprecipitation of quartz already in the veins, accompanied by the subtraction of a little sericite and possibly by the addition of minor amounts of quartz. The quartz of this stage is fine-grained to microcrystalline.

5. Deposition of pyrite.

6. Slight brecciation of the vein material, accompanied or followed by deposition of fine-grained to microcrystalline quartz, derived largely in place.

7. Deposition of sphalerite, chalcopyrite, and galena in the sequence named.

8. Deposition of gold, possibly preceded by slight brecciation.

9. Slight brecciation.

10. Deposition of fine-grained to microcrystalline quartz, derived largely in place, accompanied by deposition of minor amounts of calcite.

11. Slight brecciation.

12. Deposition of most of the calcite.

SUPERGENE ALTERATION

The writers could obtain very little information concerning the supergene alteration, for ore in the present workings is unaltered, and 


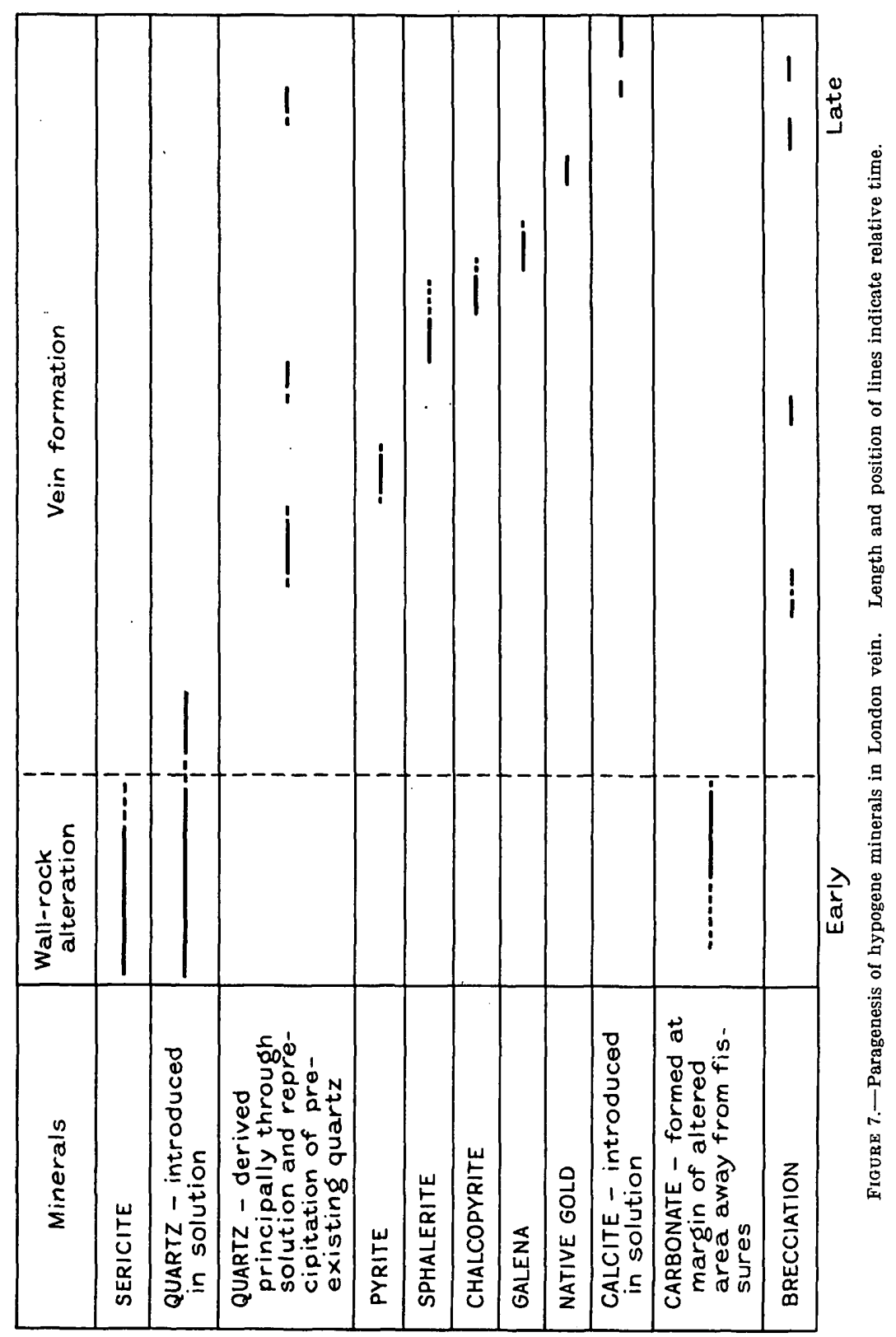


the partly oxidized ore that occurred at places in the upper parts of the North London workings was extracted years ago. The only specimens now available had to be obtained from dumps or from lean, unworked portions of the veins.

Limonite, ranging in color from pale yellow to dark brown, is the most abundant and widespread product of oxidation. It was derived from pyrite and chalcopyrite. It is most common along pyritic bands but also is distributed throughout the rock as a stain. In the pyritic bands it occurs as pseudomorphs or as earthy masses.

Minor amounts of malachite and azurite are fairly widespread, and anglesite, identified by C. S. Ross, was seen in one polished section. Other minerals probably existed in the ores. Where intensely leached the ore is somewhat porous. There is no evidence to suggest that gold was appreciably enriched.

\section{OTHER MENES OF THE LONDON VEIN SYSTEM}

\section{AMERICAN MINE}

The American is a small mine, opened in 1931, on one of the claims in the London vein system at London Mountain. It has produced more than $\$ 2,000,000$ in gold ore similar to the ore in the London mine. The location of the shaft with respect to the London mine, as surveyed by G. F. Galloway, and a geologic map of the American workings are included in plates 6 and 7 . The most recent workings have not been mapped, but they are mostly stopes on the McDonald No. 2 vein, north of the stopes in the London mine near raises 6 and 8 of the Extension level. The replacement ore body in limestone along an eastward-dipping fissure has been described on page 47 .

\section{HAVIGHORST TUNNEL}

The portal of the Havighorst tunnel is about 1,200 feet south of the South London portal. The mine workings and the underground geology are shown on the map of the London mine, plates 6 and 7 . The Havighorst tunnel has had no production but is of interest because patches of brecciated quartz-sulphide vein material were encountered in it on the west side of the London fault, and small stringers of unbrecciated vein material extend for several feet westward in fractures away from the fault. However, the vein material apparently does not extend to any distance above the tunnel level, for none was encountered in the raise close to the American shaft. Thus, these patches and stringers must represent the upward termination of the "London" vein (here not productive), which meets the London fault a few feet below the tunnel level, as shown in section $\mathrm{B}-\mathrm{B}^{\prime}$, plate 8 . Apparently, when the ore-forming solutions that deposited the London vein encountered the London fault, they deposited small quantities of vein material in the westernmost shear plane of the fault and in 
fractures extending from the fault but were prevented from ascending more than a few feet along the London fault by the large amount of impermeable clay gouge. Later, postmineral movement brecciated the vein material that was in the London fault. The location of another vein in the Havighorst tunnel that has no commercial importance is shown in plate 7 .

\section{OPHIR MINE}

The mine workings of the Ophir mine, as surveyed by G. F. Galloway, and the underground geology, including the Ophir tunnel and the Ophir shaft, are shown on the London mine map, plates 6 and 7. No veins of importance were encountered.

\section{MOSHER TUNNEL}

The Mosher tunnel likewise is included on the London mine map, plates 6 and 7 . The writers made a Brunton compass and pace traverse of the mine workings to use as a base for mapping the underground geology. This tunnel is of interest because it is on the west limb of the syncline west of the London fault. The only ore deposits encountered consisted of several narrow quartz-sulphide veinlets.

\section{LONDON-BUTTE MINE}

The London-Butte mine, formerly the Butte mine, is on the south side of South Mosquito Creek. It is the southernmost of the mine workings that cut the rocks at favorable stratigraphic borizons close to the London fault. Frank A. Aicher has kindly permitted publication of his geologic map of the underground workings. (See pls. 18 and 19.) The mine has had a small production from goldbearing quartz-sulphide ore like that in the London mine, but the vicinity has not been adequately prospected.

The locations of the known veins are shown in plates 19 and 20 . On the first level commercial ore was encountered at only one place, where the winze was sunk. On the second level the vein was stoped along a horizontal distance of 130 feet. The top of the ore shoot, which extended to the first level at only the one place mentioned, has a southerly pitch. To the north the ore shoot is cut off by the A fault, and north of the fault the mineralization was too weak for profitable mining. The vein has been named the McDonald because of its similarity in stratigraphic position to the McDonald vein in the London Extension workings, but there is no assurance that the two were once continuous.

\section{DEPOSITS IN LONDON FAUIT ZONE NORTHWEST OF LONDON MOUNTAIN}

There are many small mine workings in the area near the London fault between London Mountain and the crest of the Mosquito Range. No mineralization of importance has taken place east of the fault 
except at the Champaign mine and in the Coney workings, both of which seem to be related to large minor faults in the northeasterly belt of general mineralization rather than to the more distant London fault. As all the underground workings are caved or filled with ice, only dumps and surface exposures could be examined. The knowledge concerning mineralization obtained in this manner has been supplemented by information supplied by Mr. Frank A. Aicher and other persons. For convenience, the area is divided into three parts, each of which is discussed separately.

\section{AREA BETWEEN LONDON MOUNTAIN AND NEW YORK MOUNTANN}

\section{EXTENT OF PROSPECTING}

The area between London Mountain and New York Mountain, because of its transitional character, is discussed separately from the rest of the London vein system. Exposures are poor, but the many small pits and prospects, some of which are on quartz veins of the London type, afford evidence of extensive prospecting. Nevertheless, according to available information, valuable ore came only from the Hard-to-Beat mine. Most of the prospects are located in the narrow belt of Leadville limestone that is exposed immediately west of the London fault, and only a few in the basal part of the Weber (?) formation or the porphyry sills. From this it might be concluded that the most favorable horizons have been the least exhaustively prospected; however, the porphyry sills have been eroded where they originally were close to the London fault, so there is no assurance that veins, even if they once existed in the sills, extended away from the fault downward as far as the present surface. The most extensive of the mine workings in the area are the Venture shaft, the Hard-toBeat mine, and the Oliver Twist tunnel.

\section{VENTURE SHAFT}

The Venture shaft is 800 feet west of the former North London boarding house. It was sunk on a steep incline, toward the southwest, along a quartz vein of the London type. A former superintendent of the London mine who directed the work told Mr. Aicher that the shaft is 240 feet deep, the vein has a maximum width of 2.0 feet, and both walls are in Gray (quartz monzonite) porphyry. No part of the vein was rich enough in gold to yield ore worth shipping.

\section{HARD-TO-BEAT MINE}

The Hard-to-Beat is a small mine 1,400 feet northwest of the former North London boarding house. No records of its production are available, but the total, chiefly in gold, must have been small. The principal workings are at the surface in a highly oxidized irregularshaped ore body in a quartzite of the Weber (?) formation, 25 feet above the base, as is shown on Aicher's cross section of the Oliver 


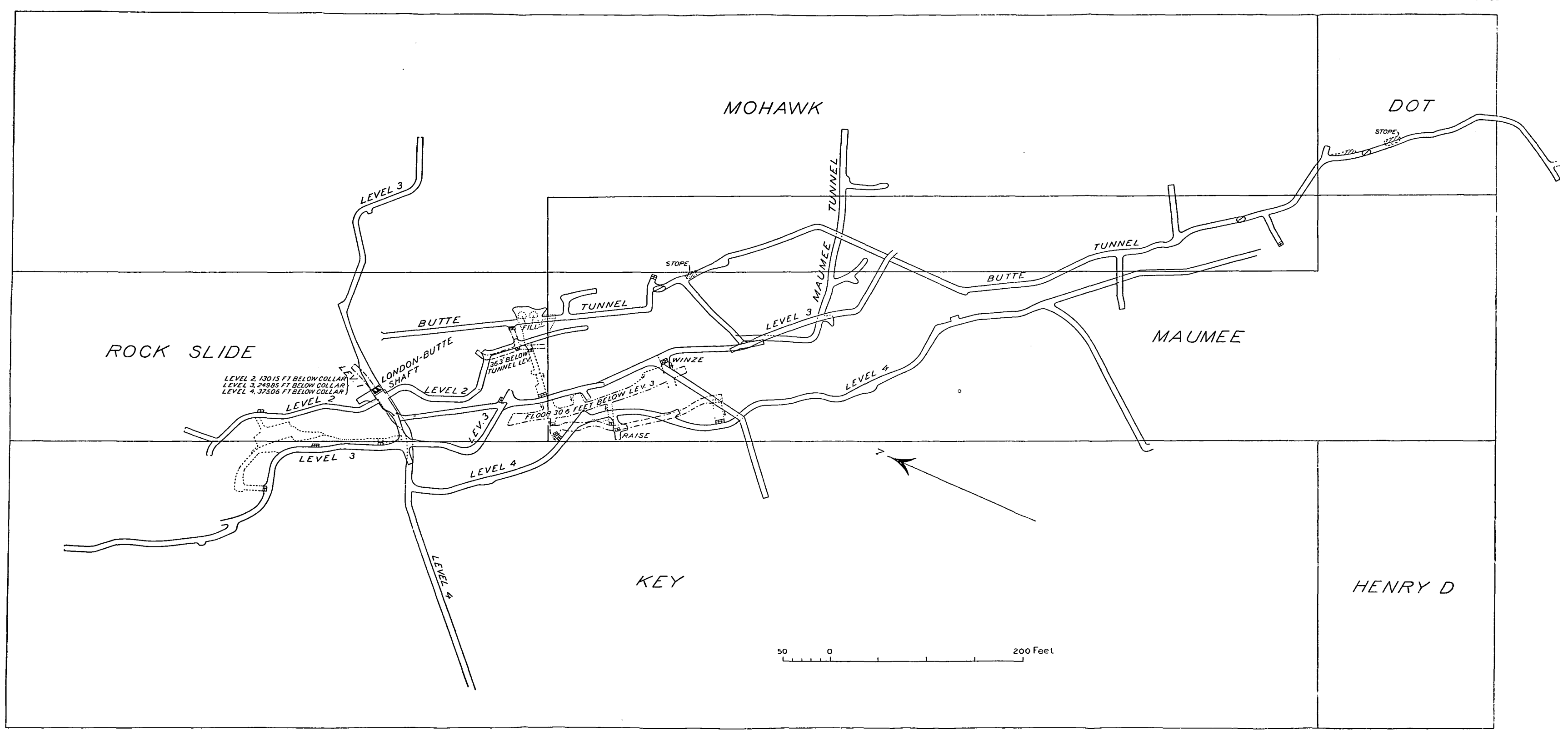




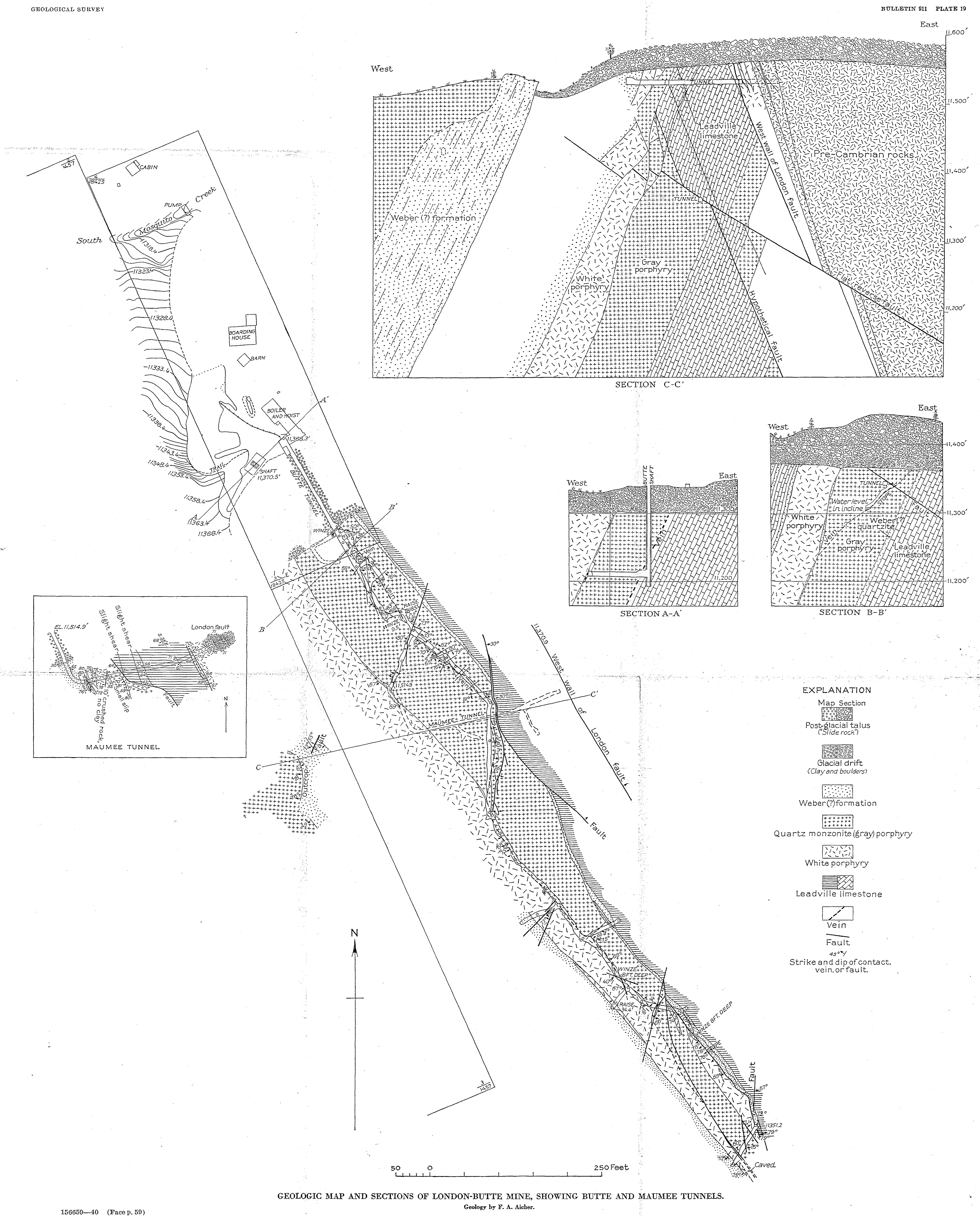


Twist tunnel (pl. 21). Lean ore seen on the dump consists of spongy quartz and subordinate limonite in partly replaced quartzite. In appearance it closely resembles the ore from some of the gold deposits in the Sawatch quartzite. Thus, the appearance and stratigraphic position of the ore are different from those of the Hard-to-Beat vein of the North London mine, whose name was derived from the Hard-toBeat mine. 'In addition to the surface workings, a short tunnel starting at the top of the Leadville limestone and extending almost due west in the Weber (?) formation encountered several curved and branching veinlets of ore composed of quartz, considerable quantities of carbonate, and subordinate amounts of the simple sulphide minerals. At places small pockets of considerably oxidized ore were especially rich in gold.

\section{OLIVER TWIST TUNNEL}

The Oliver Twist tunnel, which is the most extensive of the mine workings, was driven in order to prospect at depth for gold veins of the London type. The portal is 900 feet northeast of the Hard-toBeat mine and 1,300 feet north of the former North London boarding house. The tunnel starts in pre-Cambrian rocks on the east side of the London fault, crosses the fault, and extends some 1,000 feet through the sedimentary rocks and porphyry sills on the west side. The workings were inaccessible for several years prior to the summer of 1932 . Mr. Frank A. Aicher has kindly permitted publication of his geologic map and cross section made in 1924, to which have been added the newer workings mapped by the writers in 1932. (See pl. 21.) This map shows two quartz-sulphide veins, neither of which was workable. One occurs in a sill of quartz monzonite porphyry in the Leadville limestone on the west side of the London fault, and the other in the pre-Cambrian granite. In addition evidence of slight mineralization of the replacement type was encountered at the top of the Leadville limestone in the raise 1,700 feet from the portal.

\section{NEW YORK MOUNTAN}

New York Mountain is a small hill, indicated on the topographic map by a closed contour, 3,400 feet southeast of Mosquito Peak. An escarpment bounds it on the northeast, but the slopes are gentle in other directions. Beds just below the top of the Leadville limestone crop out at the peak and form virtually a dip slope to the southwest.

The entire output from New York Mountain has consisted of silverlead ore occurring as replacement deposits in the Leadville limestone. To judge from the extent of the workings, between 100 and 300 tons has been mined, mostly from a single stope directly beneath the peak. Weakly mineralized rock of the same type as the ore is fairly widespread. Unproductive quartz veins of the London type are said to

$156850-40-5$ 
bave been cut in the Finnerty tunnel and the Little Newton shaft, on the northeast slope of the mountain.

Sphalerite, less abundant galena, and minor amounts of pyrite and chalcopyrite are the only sulphide minerals identified megascopically in specimens collected from mine dumps and from surface exposures, but others may have existed in the ore. These minerals form isolated irregular-shaped or somewhat rounded clusters that range in size from mere specks to masses having a diameter of nearly 2 inches. Unreplaced Leadville limestone is the chief gangue constituent in all specimens, but its relative abundance varies greatly. An iron-bearing dolomite is usually about as abundant as the sulphide minerals; it forms small vuggy masses, some of which surround the sulphide clusters. Calcite occurs locally. Quartz is rare where sulphide minerals are abundant, but local areas of silicified limestone are found in the general vicinity of the ore. Small amounts of travertine and limonite are sufficiently widespread to suggest that the ores were slightly oxidized.

Microscopic examination of a polished section from one of the specimens reveals, in addition to the minerals seen megascopically, small amounts of a "gray copper" mineral (tetrahedrite, tennantite, or freibergite), with insignificant amounts of a supergene lead mineral (anglesite?) and covellite. The sequence-pyrite (oldest), sphalerite, "gray copper," galena-is indicated by the grain boundaries; the relative age of the chalcopyrite could not be determined, although it probably followed sphalerite. Veinlets of sphalerite healing cracks in a few pyrite grains show that slight brecciation intervened between the periods of deposition of these two minerals. All or nearly all of the white dolomite was formed after the galena. In spite of its rather dark megascopic color, the sphalerite is a variety low in iron, and it is free of chalcopyrite blebs.

Although the available specimens came only from material having no commercial value, they yield sufficient information to indicate that the ore bodies on New York Mountain were very similar in type to those at the Russia mine, described in a previous paper. ${ }^{51}$ However, on New York Mountain the ore bodies are smaller and less numerous, barite is absent, and the Leadville limestone is less silicified-facts all of which indicate less intense mineralization than at the Russia mine.

\section{AREA NORTHWEST OF NEW YORK MOUNTAIN}

Much of the surface in the vicinity of the London fault northwest of New York Mountain is covered with talus, and there are very few mine workings. Ore is said to have come from several workings near U. S. L. M. Little Corrine, but nothing definite is known regarding

51 Singewald, Q. D., and Butler, B. S., Preliminary report on the geology of Mount Lincoln and the Russia mine, Park County, Colo.: Colorado Sci. Soc. Proc., vol. 12, no. 12, pp. 400-406, 1931. 
the mineralogy or extent of the ore bodies. The Oxide tunnels, on the southeast spur of Mosquito Peak, are in the upper part of the Leadville limestone. They encountered some mineralized rock but apparently produced little or no ore. None of the other formations have been prospected. Except for a small, possibly faulted inlier adjoining the London fault slightly north of east of Mosquito Peak, the Weber (?) formation and its intruded porphyry sills crop out too far from the London fault to contain quartz veins of the London type.

\section{CONCLUSIONS REGARDING DEPOSITS IN LONDON FAULT ZONE NORTH OF PENNSTLVANIA MOUNTAIN}

All the ore deposits in the London fault zone north of Pennsylvania Mountain are restricted to the west side within a few hundred feet of the main fault. This restriction is due to the large amount of clay gouge that acted as a barrier to solutions ascending in permeable fissures in the footwall.

The lateral changes observed in the type and intensity of mineralization were caused by variations in three different geologic factors(1) the distance from the site of strongest mineralization, (2) the local structure - that is, the steepness with which the strata dip away from the London fault, and (3) the nature of the wall rock. To evaluate the relative importance of each factor adequately would require observation of its influence under conditions in which the other two remained constant, which obviously is impossible. Nevertheless, the data permit certain inferences that have practical applications.

London Mountain was an area of intense mineralization of the typical mesothermal type, resulting from an abundant supply of ore solutions, as is proved by the extent and richness of the ore. The relatively hard and brittle rocks from the top of the "porphyry zone" at the base of the Weber (?) formation to the pre-Cambrian rocks in the west wall of the London fault were very much fractured by the folding that preceded and accompanied the reverse faulting, which provided a permeable zone extending for several hundred feet from the fault (see figs. 5 and 6); on the other hand, in the weak rocks of the Weber (?) formation above the "porphyry zone" fissures were less abundant and were filled with gouge, so that these rocks remained impermeable. Hence, the permeable zone was bounded upward by the impermeable Weber (?) formation and eastward by the impermeable gouge of the London fault. The meeting of the two impermeable layers formed an inverted trough pitching gently to the southeast. In the "porphyry zone," and probably in the other brittle rocks, the bending of the beds opened fissures that strike nearly parallel with the strata but dip a little more gently. Ore solutions, rising along the fractured zone under the London fault, were stopped 
by the inverted trough of impermeable material and tended to migrate up the pitch along the open fissures in the "porphyry zone," thereby forming the London veins. (See figs. 5 and 6.) Good ore has been mined to a maximum distance of 600 feet west of the fault, but none has been found west of the area of pronounced folding, although it is possible that some of the solutions at places leaked out to form deposits in fissures farther west. If such deposits exist, they are probably at the top of the Leadville limestone; for where the dip is gentle no open fissures nearly parallel with the dip are likely to exist in the porphyry sills.

Farther north on New York Mountain the formations dip gently away from the London fault, so most of the ore probably formed in the upper part of the Leadville limestone. If this is true, then the small size and extent of the ore bodies indicate weak mineralization, implying that New York Mountain is about on the margin of the mineralized area. This inference is substantiated by the absence of any known ore for some distance to the northwest. It is likewise substantiated by the mineralogy of the ore-namely, the abundance of iron-bearing dolomite, the low iron content of the sphalerite, and the scarcity of pyrite and chalcopyrite, all of which are characteristic of a lower-temperature, more marginal type of mineralization than that of London Mountain.

Thus it seems that London Mountain was a center of mineralization which extended with diminished intensity as far north as New York Mountain. The available data are not specific enough to determine with certainty the location of the exact center of strongest mineralization, but the tenor of the ores in the London mine suggests that it is somewhere south of the Big raise. Moreover, it seems probable that the ore solutions migrated for some distance up the pitch of the fold, but there are no data to determine at what place they ascended through the sedimentary series. The southern limit of the mineralized area must be determined through future prospecting. The southward pitch of the folded rocks and the tendency of the ore solutions to migrate upward may have produced a more rapid decrease in the intensity of mineralization away from the center toward the south than toward the north. The changes here referred to apply to the London Mountain area as a whole and not to variations in the size and tenor of the veins caused by local variations in permeability.

The interpretation given above implies that other ore deposits in the London fault zone are associated with centers of mineralization other than the one at London Mountain. The deposits near the crest of the range probably are related to a center located somewhere between the crest of the range and the Mosquito fault but now largely obliterated by erosion. 


\section{REGION SOUTH OF PENNSTLVANIA MOUNTAIN}

\section{EXTENT OF KNOWN MENERAMIZATION}

Associated with the doubly plunging anticline at Sheep Mountain is an area of mineralization (see pl. 3) extending from the saddle at the south fork of Sacramento Creek to a point nearly 2 miles southeast of Sheep Mountain. Eastward the area extends a mile from the London fault. Apparently after ore solutions once leaked through the fault gouge, they tended to migrate upward and outward into the hanging-wall country rock as far as fissures were available, and so the resulting deposits are neither as restricted in distribution nor as large as those at London Mountain. Moreover, the area is south of the main northeasterly belt of mineralization in the Mosquito Range. All the productive mines are north of the high point on the axis-in other words, on the gentle north limb rather than the steep south limb. The ores are silver-lead replacement deposits in limestone, a type characteristic of the marginal mineralization in areas containing gold deposits.

No mineralization of any consequence whatever has been revealed by prospecting along the west side of the fault, but this is not surprising, for the rocks cropping out at the surface are stratigraphically far above the Leadville limestone and do not contain ore anywhere in the Mosquito Range. Hence the apparent barrenness of this area does not preclude the existence of ore at depth in the strata at or below the base of the Weber (?) formation.

\section{SACREMENTO MINE}

The Sacremento mine is at an altitude of about 11,250 feet on the north side of Spring Creek, a small tributary to Sacramento Creek. It is 8 miles by road from Fairplay, the nearest shipping point for ore. The road is now almost impassable for automobiles over the 3 miles nearest the mine.

Information concerning the history and production of this mine is derived from several superintendent's reports written between 1880 and 1886 and from the mine map (fig. 8). The reports and the map were furnished by the present owner, Miss Ada Dwelle, of Denver, to whom the writers are greatly indebted. The deposit was discovered in October 1878. The owners worked it until 1882, when the gross output amounted to about $\$ 175,000$. After 1882 lessees worked the mine for several years, but the output was small. Production came from a single stope at the west end of the mine. Toward the southeast the ore terminated abruptly against a fault trending $\mathrm{N} .30^{\circ} \pm \mathrm{E}$., but toward the north and west it graded into weakly mineralized limestone. The ore assayed about 10 percent in lead, 0.75 ounces to the ton in gold, and more than $\$ 200$ to the ton in silver. 
The Leadville limestone, the basal part of the Weber (?) formation, and a thick sill of quartz monzonite porphyry 30 feet above the base of the Weber (?) crop out in the immediate vicinity of the mine. These rocks dip nearly due east at an angle of about $15^{\circ}$. The ore body was a replacement deposit in the Leadville limestone, cose to the top. Its shape and position, as shown in figure 9, suggelst that replacement extended up the dip from the fault reported to be encountered in the underground workings. Hence the fault must be

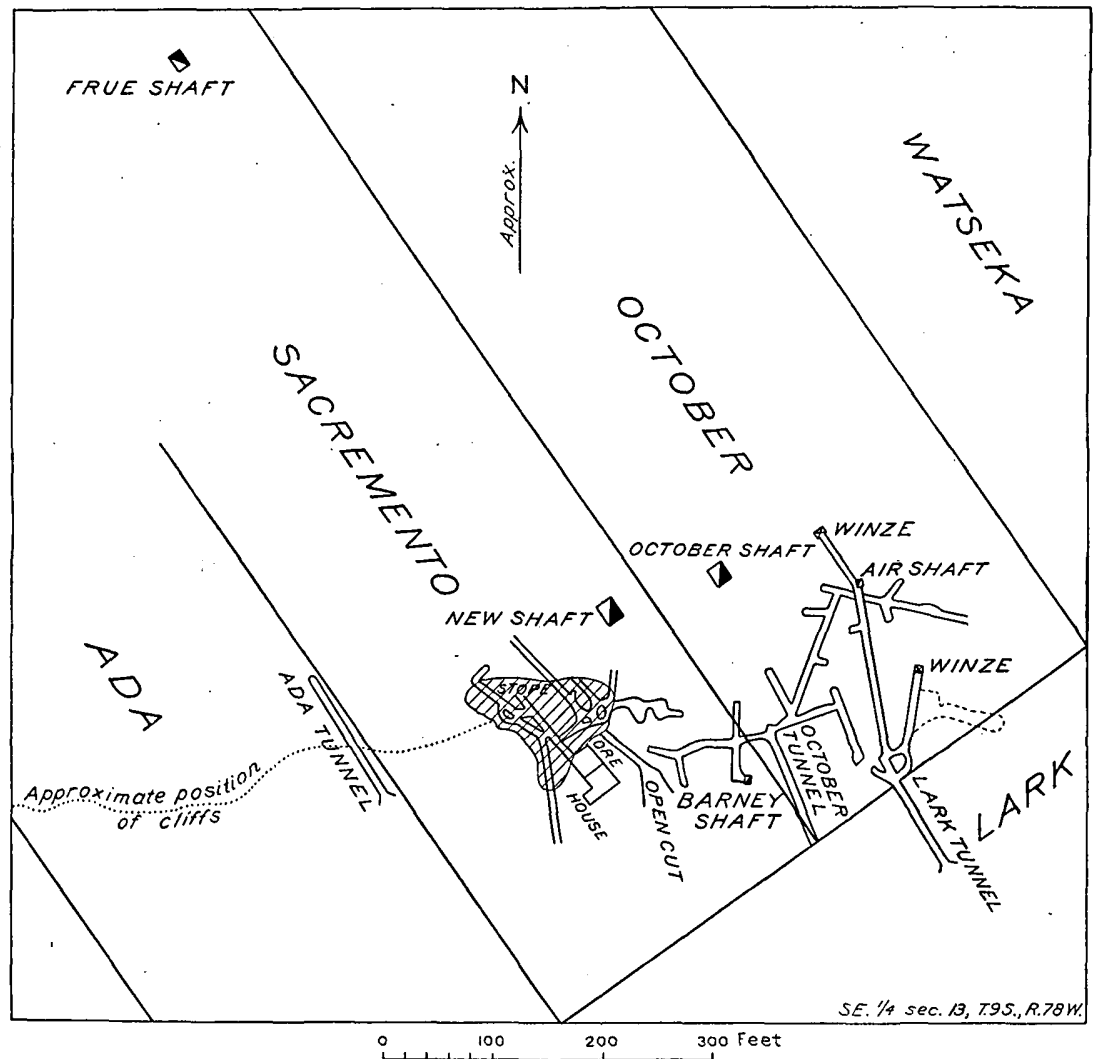

FigURE 8.--Sketch map of Sacremento mine. Made by “J. W. P.," superintendent, February 5, 1881.

of premineral age, and this would account for the absence of ore on its downthrown southeast side.

The chief gangue constituents, determined from an examination of dumps, were unreplaced Leadville limestone, white iron-bearing dolomite, barite, and jasperoid. Quartz was a very minor constituent. One of the shafts encountered large quantities of aragonite, which doubtless is supergene. Specks of galena in a few specimens and pyrite in one thin section were the only sulphide minerals seen, but it is safe to assume that simple base-metal sulphides predominated. The ore was partly oxidized, and several statements in the super- 
intendent's reports lead to the inference that supergene silver minerals were present.

The comparatively small size of the ore body, the large quantity of barite, and the scarcity of quartz are features suggesting that the deposit was formed by weak solutions at a long distance from their source. Consequently, no large bodies of ore are likely to be found in the immediate vicinity of the mine, but small bodies that extend

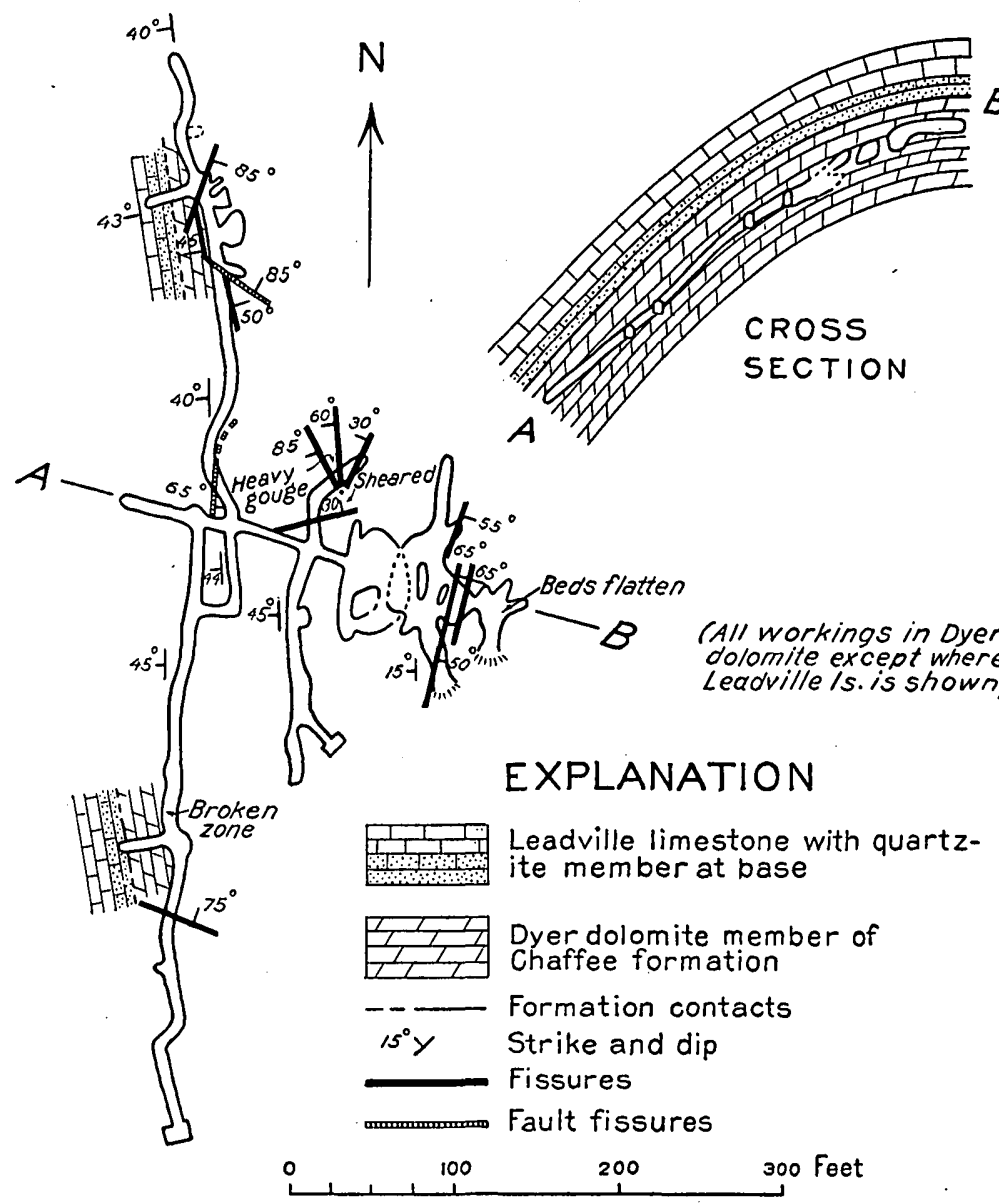

FIGURE 9.-Geologic map and section of Mudsill mine.

up the dip from faults may exist in the Leadville limestone where the Weber (?) formation or the quartz monzonite porphyry crop out.

\section{MUDSTLL MINE}

The Mudsill mine, which is reported to have had a gross production of somewhat more than $\$ 60,000$, is at the top of the cliffs north of Fourmile Creek. (See fig. 9.) A wagon road extending from the mine to the head of Spring Creek and then down Spring Creek joins the road from the Sacremento mine to Fairplay. Stopes in small 
replacement bodies of partly oxidized ore dip with the strata, at an average of $50^{\circ} \mathrm{SW}$., between the axis of the anticline and the London fault. The ore was immediately below a silicified (jasperoid) bed, 15 feet below the top of the Dyer dolomite.

No ore specimens were seen. On the dumps of small prospects nearby, however, were found white dolomite, limonite, galena, barite, calcite, kaolinite (?), small quantities of azurite and malachite, and traces of manganese oxide stain. The barite is much less abundant than at the Sacremento mine. Polished sections of galena specimens contain cerusite, anglesite, sphalerite, pyrite, and a few grains of tennantite, chalcopyrite, and luzonite.

\section{SHERWOOD MINE}

The Sherwood mine (see fig. 10), on the south side of Little Sacramento Creek, is reported to have produced nearly $\$ 50,000$. An almost impassable wagon road extends from the mine to the junction of the two forks of Sacramento Creek; thence an automobile road extends to Fairplay. The ore bodies probably were replacement veins at or close to the top of the Leadville limestone, where the strata dip steeply to the southwest near the London fault. Iron bearing dolomite and subordinate quartz were the chief gangue minerals, in addition to unreplaced limestone. Galena, pyrite, brown sphalerite, subordinate "gray copper," limonite, tennantite, and argentite, accompanied by limonite, covellite, and other supergene minerals were seen in specimens on the dump.

\section{WAGNER MINE}

The Wagner mine, at the top of the cliffs on the north side of Sheep Mountain, produced decidedly less than the Sherwood. Small replacement ore bodies were found in the middle part of the Dyer dolomite that dips $15^{\circ} \mathrm{NE}$. The gangue consisted mainly of unreplaced limestone, iron-bearing dolomite, barite, and jasperoid. Galena, light-colored sphalerite, and some supergene minerals were seen in specimens on the dump. In addition, polished sections reveal minor amounts of pyrite, tennantite, and argentite.

\section{BARCOE TUNNEL}

The Barcoe tunnel, located on the northeast face of Sheep Mountain, was recently driven to explore the west side of the London fault. No promising indications were found, and work was abandoned in the fall of 1937. As these were the only accessible underground workings adjacent to the fault south of Big Sacramento Creek, a geologic map of the tunnel (fig. 11) has been included to illustrate details of structure in this portion of the area.

\section{OTHER MANES AND PROSPECTS}

An abundance of prospect pits, shafts, and tunnels indicates widespread mineralization in the Sheep Mountain area. The greater 
number, however, have been unproductive, and only the four mines above described have yielded important quantities of ore. The mineralogy is known only in part from material now found on the dumps.

Iron-bearing dolomite is the most abundant and widespread gangue

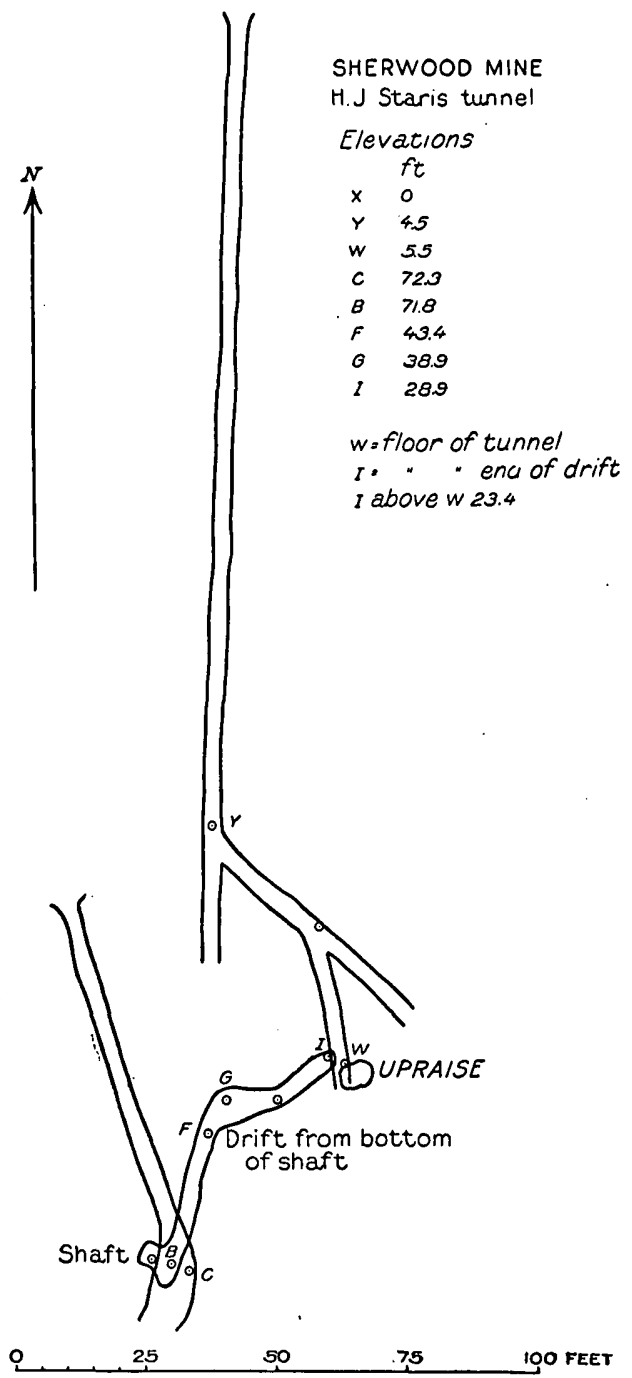

Fradre 10.-Map of Sherwood mine. Furnished by G. F. Galloway.

mineral. Barite is abundant in most prospects on Sheep Mountain and in those near the Sacremento mine, and it is moderately abundant at several places east and northeast of the Sherwood mine; on the other hand, it is absent within a triangle whose one side is along the London fault, whose base is about 2,000 feet long at",the Sherwood mine, and whose apex is the Mudsill mine. Thus, the greatest deposition of barite took place on and just beyond the margins of the productive 


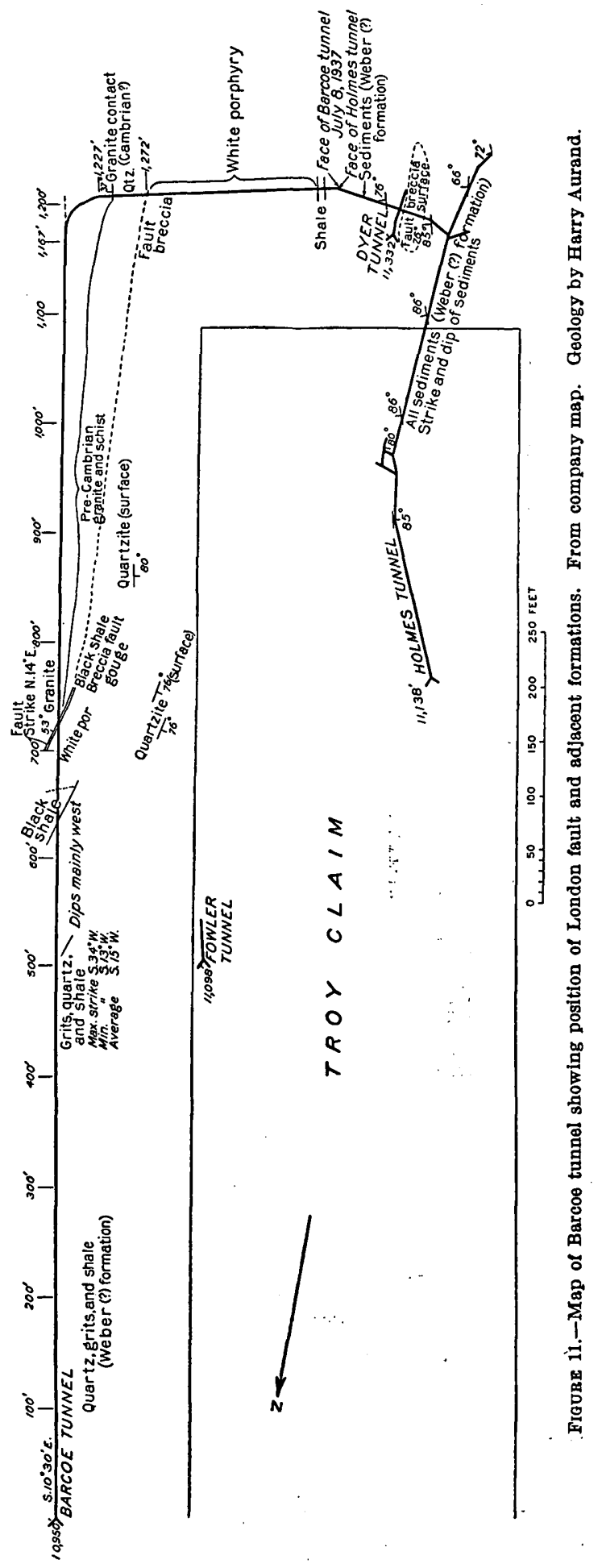


belt. Jasperoid is abundant near the London fault from the Mudsill mine to a point nearly a mile south of Sheep Mountain peak and occurs to at least some extent in nearly all the prospects; thus, its distribution is independent of the distribution of barite and of silver. Coarsergrained quartz is a sparse mineral at many localities.

As virtually all the ore bodies have been partly oxidized, information concerning the original sulphides is meager. Residual specks or masses of galena are very widespread. Sphalerite, on the other hand, though probably an abundant original constituent, was found at few places. The very light-colored variety is confined to the outermost zones. Pyrite and chalcopyrite were subordinate constituents, for neither they nor limonite are abundant except at a very few places. Pyrite seems to have been a little more abundant in the northern part of the area than elsewhere. "Gray copper" (tennantite), which apparently was widespread as a subordinate constituent, probably carried most of the silver in the productive deposits, though minor amounts of argentite are fairly widespread.

\section{CONCLUSIONS REGARDING REGION SOUTH OF PENNGYLVANIA MOUNTANN}

In spite of much prospecting in the area of widespread mineralization east of the London fault, in the vicinity of Sheep Mountain, no large mines and only a few of any commercial importance have been developed. As the mineralogy is characteristic of that in marginal deposits of certain areas farther north, the ore solutions must have been weak and distant from their source. Perhaps the most conspicuous evidence of zoning within the area is furnished by the distribution of barite, which is very abundant in a roughly semicircular belt that widens to the south. Inside of this belt and along its inner margin are several productive deposits containing silver. On the other hand, outside of the barite belt and along its outer margins, the deposits are not productive because the silver content is too low. Gold deposits are not to be expected anywhere within this mineralized area.

The strata that crop out in the footwall across the fault from the Sheep Mountain area are stratigraphically well above the impermeable shales in the lower part of the Weber (?) formation and therefore are unproductive throughout the Mosquito Range. The estimated depth to the top of the pre-Pennsylvanian formations is shown on the cross sections in plate 2 . Whether these formations or porphyry sills near the base of the Weber (?) formation contain ore probably depends on the facility with which the ore solutions in this area could leak through the London fault gouge. If the solutions deposited most of their metal content on the footwall side of the fault, as at London Mountain, deposits on the hanging-wall side should be of a marginal type, like those in the Sheep Mountain area. On the other 
hand, even if no deposition took place west of the fault and the mineralization east of the fault utilized virtually the entire metal content of the solutions, the resulting deposits might be marginal in type owing to the remoteness of the area from the main northeasterly belt of mineralization in the range. Hence the available data are not sufficient to answer the question, though the known presence of considerable gouge in the fault at Sheep Mountain and the large displacement on the fault suggest that the footwall area has some possibilities.

\section{SUGGESTIONS FOR PROSPECTING}

\section{REGION NORTH OF PENNSTIVANIA MOUNTAIN}

In the London fault zone north of Pennsylvania Mountain no large ore deposits may be expected on the east side of the fault. On the west side of the fault, at London Mountain, the "porphyry zone," consisting of interfingered sills of White porphyry and quartz monzonite porphyry with included lenses and layers of the Weber (?) formation, has yielded most of the production and therefore is regarded most favorably. It evidently consists of rock favorable to precipitation of the London type of gold ore and warrants exploration wherever the other necessary conditions, favorable structure, and former presence of ore solutions are fulfilled. Present development rather definitely indicates that gold ore similar in quantity and quality to that at London Mountain is not to be expected toward the northwest. Toward the southeast, however, the limit has not yet been located, and exploration to find this limit seems justified. As far south as raise 8 of the London Extension mine there is no indication of any change in mineral composition of the ore, except for a progressive southward increase in the gold content, and development work farther south has been insufficient to prospect the area adequately. Recent work proves that the gold mineralization extends at least as far as the London-Butte mine. It is to be expected that as the southern margin of the mineralized area is approached there will be a change in mineral content-analogous either to the change at the north or to higher-temperature type of mineralization; but, owing to the tendency of the ore-forming solutions to travel northwestward up the pitch of the fold, the changes toward the southeast may be more abrupt than those toward the northwest.

The Leadville limestone shows the effects of mineralization at several places in this area. It contained all of the silver-lead ore produced but has yielded only a very small part of the gold ore. Experience in exploring this limestone at London Mountain has not given much encouragement, but it should be regarded as having some possibilities. Farther north, from London Mountain to the northeast spur of Mosquito Peak, surface prospecting has virtually eliminated 
all chance of future discoveries, and still farther north no ore has been discovered except near the crest of the range.

The Sawatch quartzite, which contains gold ores at some places in the district, has not been prospected in the London Mountain area, and thus there is no basis for an opinion as to whether it may. prove productive. As the Peerless shale member of the quartzite is a much less effective dam to ore solutions than the Weber (?) formations, it is not likely that ore bodies as extensive as those in the "porphyry zone" will be found. However, in view of the favorable character of the Sawatch quartzite in other areas, there is justification for some prospecting of the horizon in the London Mountain area, but it should be undertaken with the understanding that the chance of success is an open question. It should be kept in mind that the exact locality at which the Sawatch quartzite is most likely to contain ore is not known. The ore-forming solutions undoubtedly migrated for some distance up the pitch of the fold in the "porphyry zone," and development work has not yet yielded sufficient data to determine the place at which the solutions entered the "porphyry. zone"; consequently, it is not known at what place the ore solutions passed through the Sawatch quartzite, nor whether the quartzite contained fissures that permitted part of the solutions to migrate up the pitch in a manner similar to the migration in the "porphyry zone."

In the triangular area bounded by South Mosquito Creek, the crest of the Mosquito Range, and the syncline west of the London fault the sedimentary formations have a regional dip to the southeast, and the rocks exposed at the surface, except for several small outcrops of Leadville limestone, consist of the Weber (?) formation or porphyry sills in the Weber (?). The fact that none of the pits and shafts in this area show evidence of economically important mineralization does not preclude the existence of ore bodies in the underlying Leadville limestone. However, the area is not a favorable one for prospecting, because the intensely mineralized ground near the London fault suggests that the fault zone served as a trunk channel and that very little of the ore-forming solutions spread far into the surrounding ground.

\section{REGION SOUTH OF PENNSYLVANIA MOUNTAIN}

From a microscopic study, made by R. D. Butler, of ores south of Pennsylvania Mountain, the Sherwood mine apparently is the center of the highest temperature deposition ${ }^{51}$ within the mineralized area east of the London fault. This may either be a center independent of the London, or a local subcenter marginal to the London. In the former case, the most favorable area for prospecting west of the London fault would lie between Fourmile and Little Sacramento

81 Butler, R. D., oral communication, 1937. 
Creeks, whereas in the latter case the most favorable area would lie between Little Sacramento Creek and the London-Butte mine. Exploration, which may be done by diamond drilling, will be expensive, however, owing to the great depth of the favorable horizons. Care should be exercised to locate the holes so that the favorable horizons are reached within a few hundred feet of the fault, which presumably will be farther east than at the surface. If ore is found, it may be either gold or silver-lead.

East of the London fault no large ore bodies are likely to be found, but there may be small silver-lead deposits at the top of the Leadville limestone where it is covered by the Weber (?) formation or porphyry sills in the Weber (?) formation. Such concealed ore bodies are most likely to exist where there is some evidence of mineralization at the surface, and this evidence, therefore, may be used as a guide to locating favorable areas. Diamond drilling should then follow on the northwest side of faults whose trends are northeastward and whose displacement is up on the northwest side. The mineral composition and texture of the ores that may be expected in this region do not adapt them to geophysical prospecting, except possibly where they are very close to the surface. 


\section{INDEX} Abstract..... Page
Acknowledgments for aid.
Alma-Horseshoe district, geologic sections of.
glaciation of
local centers of mineralization in 2
ore deposits in, character and distribution

mutual relations of.

origin of $34-35$

relation of, to those at Leadville..... 33

Amerlcan wine, features of.............. 56, pl. 7

Barcoe tunnel, features of

66,68

Behre, C. H., Jr., quoted

Butte mine. See London-Butte mine.

Calcite, paragenesis of.

Cambrian rocks, character and distribution of -

Chaffee formation, character and distribution of $\ldots \ldots \ldots$ 12-13, pl. 1

Chalcopyrite, paragenesis of.. $52-53,55$, pls. $16,17, A$

Climate of the area.

Cooper Gulch fault, features of ...... 23, pls, 1,3

Copper, production of. -36-37

Devonian rocks, character and distribution of . ..................... 8,12-13, pl. 1

Dikes, character and occurrence of........ 15-16, pl. 1 Dyer dolomite, character and distribution of .

Galena, paragenesis of $52-53$, 55 , pls. $15, B, 16, B, C, 17, A, B$ Gangue minerals, paragenesis of . . 50-51, 55, pls. 10-13 Geography of the area.

Geology of the area.

Glaciation of the ares

Gold, occurrence of

, pls. 4, 5

paragenesis of. 29,30

production of.

Gold deposits, relation of, to those at Leadville.

Hard-to-Beat mine, features of. $56-57$, pl. 7

Havinghorst tunnel, features of

Henderson, C. W., table by 36-37

Igneous rocks, character and distribution of ............... 7, 15-22, 37-38, pl. 1

Lead, occurrence of $29,59,63$ production of

Lead deposits, relation of, to those at Lead. ville
Leadville, ore facies at ores at, relations of, to those at Alma...... 33 Leadville limestone, character and distribution of .................. 8, 13-14, pl. 1 ore in............... 29,47,48, 58-61, 64, 66, 70 Lincoln porphyry, character and distribution of ..................... 16, 21-22, pl. 1

Location of the area. . ....................... 4, London-Butte mine, features of.......-57, pls. $18-20$ London fault, description of ....... 22-27, pls. 1, 3 strike and dip of . . . .

London mine, geology of ......37-43, 44, 45, pls. 7,8 history and production of . . . . . . location of . . . . . . ore in, alteration of . . . . . . 54-56 general appearance of ........... $48-49$ mineralogy of .............. 49-54, pls. 9-17 occurrence of .............. $44-48$, pl. 8 plan and section of .................. pls. 6-8

London Mountain, geologic history of....... 43 ore deposits in and near. . . . . . . . . . . . 35-62

London vein, features of ........ 44-46, pls. 10-17 production from relation of, to enclosing rocks.......... $47-48$

London vein system, location of . . . . . . . . 35-36 mines of

Loughlin, G. F., summary of zonal relations of Leadville ores by .................. 32-33

McDonald vein, features of................. 46-47 relation of, to enclosing rocks............. 47-48

Manitou limestone, character and distribution of . . . . . $11 . .12$, pl. 1

Maroon formation, character and occurrence of . 15

Mineralization, local centers of...... 33-34, pl. 3 north of Pennsylvania Mountain.. 61-62, 70-71

south of Pennsylvania Mountain

$63,71-72$

pl. 3

Minerals, paragenesis of ..... 49-54, 55, 60, pls. $9-17$ Mississippian rocks, character and distribution of....... 8, 13-14, pl. 1

Monzonitic diorite porphyry, character and occurrence of ............ 16, 19, pl. 1

Moore, C. J., quoted........................ 36 Mosher tunnel, features of............ 57,7 Mudsill mine, features of . . . . . . $65-66$

New York Mountain, ore deposits in and near $58-61,62$

Oliver Twist tunnel, features of. 59, pl. 21 33 Ophir mine, features of ............ 57, pls. 6,7 
Ordovician rocks, character and distribution of ........................ 8,11-12, pl. 1

Ore deposits, facies of, at Leadville . . . . ...... 31-33 mineralization of . ............. 33-34, 61-63, 69-70 near Pennsylvanis Mountain ............. 61-70 northwest of London Mountain.......... 57-61 occurrence of, in Leadville limestone $48,58-61,64,66,70$ reglonal relations of $48,58-61,64,66,70$

See also Alms district; London vein system; and names of individual mines.

Paleozoic rocks, character and distribution of. 7-15, $37, \mathrm{pl} .1$

Paragenesis of minerals $49-54,55,60$, pls. $2-17$

Parting quartzite, character and distribution of. $\ldots \ldots, \ldots, 12, \mathrm{pl}, 1$

Peerless shale, character and distribution of ... 8-10,

Pennsylvania Mountain, ore deposits near

$11, \mathrm{pl} .1$

prospecting near 70-72

Pennsylvanian rocks, character and distribu. tion of. $8,14, \mathrm{pl} .1$

Pennsylvanian (?) rocks, character and distribution of

Permian (?) rocks, character and occurrence of.

Porphyry, character and distribution of ..... 16-22,

$$
\text { prospecting for ore in ............. } 37-39, \text { pl. } 1
$$

Pre-Cambrian rocks, character and correlation of.

70

occurrence of 37, pl. 1

Prospecting in the ares ............. 57-58, 70-72

Pyrite, paragenesis of.... 51-52, 55, 60, pls. 14, 15, $A$

Quartz, paragenests of 50-51, 55, pIs. 10-13
Page

Quartz monzonite porphyry, occurrence of ... 16,

Quaternary geology, economic importance of. 27

Rocks of the area, character and distribution

of $\ldots . . . . . . . . . . . .7-22,37-39,63,69$, pl. 1

Routes of travel ............................. 6

Sacramento mine, description of .............. 63-65

Sawatch formation, gold in................... 30,33

Sawatch quartzite, character and distribution

of

prospecting for ore in $\ldots$

Sheep Mountain, mineralization in vicinity of . 69-70

Sherman fault, features of .................... 23

Sherwood mine, features of .................. 66,67

Sills, character and occurrence of ............. 15-16

Silver, occurrence of..................... 29, 59, 63, 69

production of ........................ $36-37$

Silver deposits, relation of, to those at Leadville.............................. 33

Sphalerite, paragenesis of ................. 52-53,

55,60 , pls. $16, A, B, 17, A$

Stocks, character and occurrence of ........... 15-16 Structure of the area.... 22-27, 39-43, 45, pls. 1-3, 8,

19,21

19,21

55,60 , pls. $14-16,17, A$

Tertiary (?) rocks, character and distribution

Vegetation of the area

Venture shaft, features of $\ldots . . . . . . . . . . . . . .58$

Wagner mine, features of ...................... 66

Weber (?) formation, character and distribution of . . ........... 8, 14, 38-39, pl. 